\title{
RADIOSENSITIVITY IN PLANTS *
}

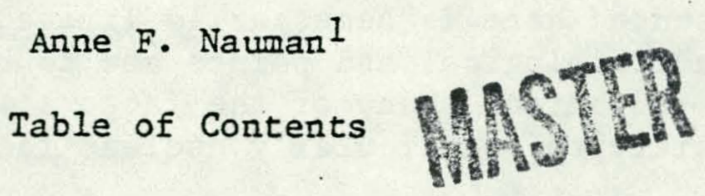

Page

1. Introduction.............................. 2

2. Historical notes.......................... 3

3. Methods for determining radiosensitivity

(a) Types and sources of radiation.................4

(b) Exposure and exposure rate.................. 5

(c) Experimental end points.................... 5

(d) Survival curves.......................... 6

4. Correlation of nuclear factors with radiosensitivity

(a) Nuclear volume and nuclear DNA content.......... 7

(b) Interphase chromosome volume and chromosomal DNA content................... 8

(c) Chromosome number......................... 10

(d) Related factors........................... 10

5. Correlation of biological, environmental and experimental factors with radiosensitivity........... 11

6. Author's note............................ 14

7. References............................. 16

8. Appendix

(a) Methods for determining nuclear factors used in prediction of plant radiosensitivity $\ldots \ldots \ldots \ldots \ldots 24$

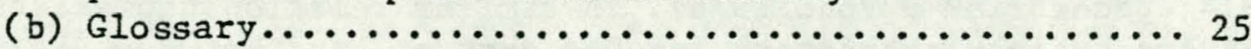

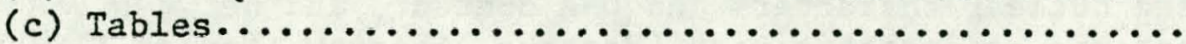

${ }^{1}$ Department of Biology, Brookhaven National Laboratory, Upton, New York 11973, U.S.A.

*Research carried out under the auspices of the United States Department of Energy under contract No. DE-AC02-76CH00016. 


\section{DISCLAIMER}

This report was prepared as an account of work sponsored by an agency of the United States Government. Neither the United States Government nor any agency Thereof, nor any of their employees, makes any warranty, express or implied, or assumes any legal liability or responsibility for the accuracy, completeness, or usefulness of any information, apparatus, product, or process disclosed, or represents that its use would not infringe privately owned rights. Reference herein to any specific commercial product, process, or service by trade name, trademark, manufacturer, or otherwise does not necessarily constitute or imply its endorsement, recommendation, or favoring by the United States Government or any agency thereof. The views and opinions of authors expressed herein do not necessarily state or reflect those of the United States Government or any agency thereof. 


\section{DISCLAIMER}

Portions of this document may be illegible in electronic image products. Images are produced from the best available original document. 


\section{Introduction}

The aim of this chapter is to present a compilation of available data on the sensitivity of plants to ionizing radiation, and to provide basic information on methods of deteimining such sensitivities, or of estimating radiosensitivities by calculation of the nuclear factors upon which they depend. The scope of the data presented here is necessarily limited to the most generally useful radiobiological end points and to the most comonly-used types of radiation. Many of the factors which influence radiosensitivity, particularly nuclear factors, will be discussed.

Emphasis will be upon whole-plant studies done at Brookhaven National Laboratory by A. H. Sparrow and his associates, since these studies are the source of most of the available radiosensitivity data and of all the sensitivity predictions listed here. More detailed information on whole-plant irradiation methods, data interpretation and prediction criteria may be found in earlier reviews by Sparrow, Schwemer \& Bottino (1971), Sparrow \& Schwenmer (1974) and Underbrink \& Pond (1976). Seed irradiation data are given for several end points; additional data on seed irradiation have been compiled by Osborne \& Lunden (1961) and Osborne \& Constantin (1966).

Data presented here include summaries of experimentallydetermined radiosensitivities at various end points for both herbaceous and woody higher plants, and for a few species of ferns and lower plants. The algae and fung $i$ have not been considered here due to space limitations. However, radiosensitivities have been determined for 23 species of blue-green algae (Kraus 1969), 47 species of lichens (Woodwell \& Gannutz 1967), and the green algae Chlorella and Chlamydomonas (Posner \& Sparrow 1964).

In the major tables appended here, data on nuclear characters are listed for over a thousand species of higher plants, together with derived estimations of radiosensitivities and of $3 \mathrm{C}_{\text {. }}$ DNA content. The sensitivity estimates may be considered to be fairly reliable (within a factor of two, over a range of nearly 300-fold), since the relationship of nuclear characters to radiosensitivity has been well-established (Sparrow \& Schwemmer 1974; Underbrink \& Pond 1976). A similar relationship exists between nuclear characters and DNA content, and between DNA content and radiosensitivity (Baetcke, Sparrow, Nauman \& Schwemer 1967). Direct determination of DNA content by Feulgen microspectrophotometry or by chemical extraction is obviously preferable to estimation of DNA content based upon nuclear volume; however, a plot of nuclear volumes against spectrophotometricallyor chemically-determined $3 \mathrm{C}$ DNA for over 100 species shows an 
excellent correlation (Fig. 1). Further, the entire body of estimated-DNA data 1 isted here is consistent, having issued from a single laboratory using standardized techniques. Therefore, estimated 3C DNA contents are included in these tatles, in the expectation that they may serve as a useful supplement to more precise DNA values presented elsewhere in this volume. The primary purpose of the tables, however, is to present a comprehensive sumary of data on plant radiosensitivity and on related nuclear factors, which should prove to be a valuable source of information for the radiobiologist, cytologist, cytotaxonomist, or the ecologist requiring an estimation of probable effects of radiation upon plant populations.

\section{Historisal notes}

Prior to the availability of large and relatively inexpensive sources of ionizing radiation, plant radiosensitivity studies were few and 1 imited. The first major facility for plant irradiation was the ${ }^{60} \mathrm{Co}$ gama field installed at Brookhaven National Laboratory in 1948. Similar facilities were later constructed at other institutions throughout the world (Sparrow 1960). Although some use was made of the Brookhaven gama field for the production of useful mutations in crop and ornamental plants (Sparrow \& Konzak 1958), its primary use was as a radiobiological research tool. The ability to irradiate many different species under the same environmental conditions, and at a wide range of exposures and exposure rates, made it possible to study the nature and extent of the large differences in radiosensitivity which exist among plant species. The subsequent development of more versatile and sophisticated means of irradiation, such as a fallout decay simulator and a controlled-environment irradiation facility (Sparrow 1966), further enhanced experimental capability. In addition, a gama source placed in a forest community at Brookhaven permitted observation of long-term radiation effects on a natural ecosystem (Woodwell \& Sparrow 1965; Woodwell \& Rebuck 1967; Woodwel1 \& Whittaker 1968).

A major part of both pioneering and later work in comparative plant radiosensitivity was done at Brookhaven by Sparrow and his colleagues. Early in their work they observed a wide range in sensitivity among species, and noted that increased sensitivity appeared to be correlated with such nuclear factors as increased chromosome size (Sparrow \& Christensen 1953; Sparrow \& Gunckel 1956) and increased nuclear volume and nuclear DNA content (Sparrow \& Miksche 1961; Sparrow, Cuany, Miksche \& Schairer 1961). Further experimentation and quantification demonstrated convincingly that the major determining nuclear factor in plant radiosensitivity was the size of an average interphase chromosome, whether expressed as chromosome volume (Sparrow 1965b; Sparrow, Sparrow, Thompson \& Schairer 1965) or as DNA content per 
chromosome (Baetcke, Sparrow, Nauman \& Schwemmer 1967). Later studies gave still further confirmation of the correlation between various sensitivity endpoints and chromosome size (Sparrow, Rogers \& Schwemer 1968; Sparrow, Schwemer \& Bottino 1971; Sparrow \& Schwemmer 1974). Thus it became possible, on the basis of interphase chromosome volume (ICV), to predict the sensitivity of a previously-untested plant species, or even, as shown by Sparrow \& Schwemer (1974), to construct a predicted survival curve.

A bibliography of early plant radiobiological work was compiled by Sparrow, Binnington \& Pond (1958), and more recent studies in comparative plant radiosensitivity have been summarized in a comprehensive review by Underbrink \& Pond (1976).

\section{Methods for determiuing radiogenoitivity}

\section{(a) Types and sources of radiation}

The basic types of ionizing radiation used in the study of plant radiosensitivity are electromagnetic ( $X$ rays, gamna rays) and particulate (neutrons, clectrons, protons, alpha or beta particles). Ultra-violet rays, although nonionizing, are occasionally used. This discussion will be concerned only with $\mathrm{X}$ and gamma rays, since they have been the basis for most radiosensitivity studies by virtue of their being the easiest and most economical to use, the most readily available, and the most versarile. The convenience of an $X$-ray machine makes $X$ rays more useful than gamma rays for acute exposures of small plants, portions of plants, seeds, or cultures of unicellular. organisms.

Gamma rays are uniquely suited to studies of chronic irradiation of growing plants, and were initially used at Brookhaven in such facilities as the ganma field and gama greenhouse, with plants arranged in isodose arcs around a ${ }^{60} \mathrm{Co}$ or 137Cs source. The latter is generally preferable because of its longer half-life and lower energy which necessitates less shielding. Tater studies using acute exposures as well as more carefully-controlled chronic exposures have utilized a controlled-environment radiation facility where several $137 \mathrm{Cs}$ sources of various strengths were used. The largest of these sources. ( $12000 \mathrm{Ci}$ ) provides for selective attenuation of exposure by means of a series of 5 concentric telescoping shields which provide a wide range of exposure rates with in a relatively small space, and permits exposures to be done under conditions of controlled temperature and humidity. This system is also adaptable for simulating the decreasing radiation levels associated with fallout by sequentially telescoping the shields to reduce the exposure rate at appropriate intervals (Sparrow \& Puglielli 1969). This facility and other types of gama sources are described in greater detail by Sparrow \& Puglielli (1969) and by Sparrow (1961, 1966). 


\section{(b) Exposure and exposure rate}

The units of radiation in general use are the Roentgen ( $R$ ) and the rad. The Roentgen is the more commonly used in plant studies, but since they differ by a very small factor ( $1 \mathrm{rad} \simeq 0.96 \mathrm{R}$ ), they may for all practical purposes be used interchangeably (U. S. Bureau of Standards Handbook 85, 1962).

Total exposure may be thought of as the total amount of radiation received, and exposure rate as the amount of radiation received per given unit of time. Exposures may be acute or chronic. There is no clear dividing point, but generally with acute irradiations the total exposure is given in a short period of time (minutes or hours) at a relatively high exposure rate, while chronic exposures last for longer periods, sometimes years, at a constant and relatively low exposure rate. In most of the irradiation studies reported from Brookhaven after 1966, a standard acute gamma irradiation treatment was given in 16 hours, with the desired total exposure obtained by varying the exposure rate; chronic exposures generally lasted for about 8 - 12 weeks for herbaceous plants and up to 8 years for woody plants. In fallout decay simulation (FDS) studies, exposure rate begins at a high level and is reduced in stepwise fashion over a 36-hour period to simulate radioactive fallout decay.

\section{(c) Experimental end points}

Comparisons of plant radiobiological data are mede more difficult by the diversity of end points which may be scored. The most commonly assessed end points result either from loss of reproductive integrity of meristematic or reproductive cells or from direct damage to chromosomes.

Meristematic damage is generally reflected in growth inhibition or plant mortality. In earlier studies, especially with chronic irradiation, damage was estimated in terms of either slight or severe growth inhibition, defined as about 80-90 percent or 15 percent of control growth, respectively. However the criteria for determining these two end points were somewhat imprecise, leading to difficulties in quantitation and statistical analysis. In later studies, lethality has proven to be a much more accurate and useful end point. Lethality is expressed as $L D_{n}$, a term which indicates the exposure in $R$ that will reduce survival by $n$ percent from the control value.

Damage to plant reproductive tissue may be assessed through such end points as percent of pollen abortion (Yamakawa \& Sparrow 1966; Underbrink, Sparrow, Pond, Takahashi \& Kappas 1973) or reduction in seed set (Yamakawa \& Sparrow 1965). Following irradiation of seeds, damage may be expressed in decreased 
germinability of seeds or in decreased growth or survival of seedlings (Osborne \& Lunden 1961; Osborne \& Constantin 1966). Chromosome damage may be evaluated by scoring for numbers of chromosome aberrations, chromosome fragments, or micronuclei (Evans \& Sparrow 1961; Sparrow \& Evans 1961). Somatic color mutations in stamen hair cells of Tradescantia flowers have proven to be a highly useful end point, since the unique sensitivity of these cells makes possible the detection and evaluation of the effects of extremely low doses of radiation (Sparrow, Underbrink \& Rossi 1972; Underbrink, Schairer \& Sparrow 1973). Somatic color mutations may also be scored in flower petals (Sparrow, Baetcke, Shaver \& Pond 1968). More detailed discussion and more complete references on all of these end points may be found in Underbrink \& Pond (1976).

\section{(d) Survival curves}

A survival curve is constructed by plotting log of plant survival as percent of control against each exposure given. As shown in Figure 2, these curves generally have a shoulder of varying width, where the effect on survival is negligible, before they turn over and become exponential. After fitting a curve to the data points, $L D_{n}$ may be determined by taking 100 - $n$ percent survival ( $n$ percent lethality) on the $y$ axis and reading off the appropriate exposure from the $x$ axis.

Other parameters which may be calculated from a survival curve are $D_{0}$ and $D_{g}$, as shown in Figure $2 . D_{0}$ is a measure of the steepness of the slope, and is the dose that reduces survival to 37 percent on the exponential portion of the curve. It is thought to indicate the dose necessary to produce an average of one hit per target. $D_{0}$ may be determined by taking an arbitrary level of survival from the straight-line portion of the survival curve (a in Fig. 2), and determining the dose necessary to reduce that survival level by 63 percent, or conversely to 37 percent of the original level (b in Fig. 2). For example, in Fig. 2, $a=40 \%$ Juryival, at $2 U \mathrm{kek}$; $=37 \%$ of $a$ or $14.8 \%$ ourvival, ac $28 \mathrm{kR}$; and $D_{0}$ is the difference between these two doses, or $8 \mathrm{kR}$. $D_{0}$ may also be determined by taking the reciprocal of the slope of the straight-line portion of the curve after computing a least-squares best fit. $D_{q}$ is a measure of shoulder width, and is the point on the $x$ axis at which the exponential portion of the curve, extrapolated upward, intersects 100 percent survival (see Fig. 2). $D_{q}$ is considered to represent the dose below which cells are able to repair radiation-induced damage.

Although $D_{0}$ and $D_{q}$ are generally used only for single-celled systems, these parameters have been adapted to whole-plant studies by Sparrow \& Schwemer (1974), who have shown them to be highly correlated with chromosome size (Fig. 3). Therefore, given the ICV of a species, the whole-plant $D_{0}$ and $D_{q}$, as well as other 
mortality end points; may be estimated, and thus a predicted survival curve may be constructed. These relationships are discussed in greater detail by Sparrow \& Schwemer (1974) and by Underbrink \& Pond (1976).

4. Correlation of nuclear factors with radiosensitivity

(a) Nuclear volume and nuclear DNA content

The first quantitative investigation of nuclear factors as related to plant radiosensitivity focused upon nuclear size (Sparrow \& Miksche 1961). Although preliminary observations had indicated an apparent correlation of sensitivity with chromosome size (the larger the chromosomes the lower the dose needed to reach a specified end point) (Sparrow \& Christiansen 1953; Sparrow \& Gunckel 1956), the quantitative measurement of metaphase chromosomes for a large number of species would have been prohibitively tedious and time-consuming. Therefore since there appeared to be a close correlation between metaphase chromosome size and interphase nuclear volume (Sparrow \& Miksche 1961), the more easily-determined nuclear volume was measured instead.

The criterion of radiation damage in these early studies was severe growth inhibition, or $15 \%$ of control growth, and it was assumed that such inhibition was caused by loss of reproductive integrity of the cells in the vegetative meristem; therefore, the nuclei initially selected for measurement in control plants were thost in the actively proliferating portion of the shoot meristem. Nuclei of the root meristem were al so measured, and their average size was found not to vary significantly from that of shoot nuclei (Sparrow \& Miksche 1961), an observation which was confirmed by later studies (Baetcke, Sparrow, Nauman \& Schwemer 1967; Sparrow \& Nauman, unpublished data).

The results of this first investigation (Sparrow \& Miksche 1961) showed a close inverse correlation between the volume of the interphase meristematic nucleus in shoot or root and the exposure necessary to produce severe growth inhibition in 23 plant species (see also Sparrow, Cuany, Miksche \& Schairer 1961). They also showed a direct positive correlation between nuclear volume and nuclear DNA content, later confirmed by Baetcke, Sparrow, Nauman \& Schwemer (1967) (Fig. 4a), who concomitantly showed a direct correlation between DNA per chromosome and ICV (Fig. 4b). A similar correlation was found between nuclear DNA content and radiosensitivity (Sparrow \& Miksche 1961; Bowen 1962). Hence a direct positive correlation between nuclear volume and radiosensitivity was inferred. However, these early studies were limited to diploid species with relatively little variation in chromosome number, and later work, outlined below, showed that 
nuclear volume or nuclear DNA content are correlated with radiosensitivity only so long as there is little variation in chromosome number; when chromosome number varies widely, the correlation does not hold. Therefore nuclear volume cannot be used as the basis for any comprehensive system for prediction of plant radiosensitivity.

(b) Interphase chromosome volume and chromosomal DNA content

Sparrow \& Mikcche (1961), while establishing the correlations noted above, also noted that there was a better correlation of radiosensitivity with DNA content per chromosome than with DNA per cell. In view of this apparent relationship between sensitivity and chromosomal DNA content, and of the demonstrated relationship between nuclear DNA content and nuclear volume, it seemed logical to assume that there would be a similar correlation between sensitivity and average interphase chromosomal volume, or ICV. ICV could be estimated easily by dividing nuclear volume by somatic chromosome number (Sparrow \& Evans 1961). It was subsequently shown that there was indeed a close correlation between ICV and acute lethal dose, with the plotted regression having a slope not significantly different from-1 (Sparrow, Schairer \& Sparrow 1961). Further work by Baetcke, Sparrow, Nauman \& Schwemer (1967) confirmed the correlations of chromosomal DNA with radiosensitivity (Fig. 5a) and of ICV with radiosensitivity (Fig. 5b).

Other studies provided additional confirmation of the direct positive correlation of ICV with radiosensitivity, which was found to hold for various lethality or growth inhibition end points in both acute and chronic exposures of herbaceous plants (Sparrow \& Schwemer 1974; Sparrow, Sparrow, Thompson \& Schairer 1965) (Figs. 6,7 ), and in chronic exposures of woody plants (Sparrow, Schwemer, Klug \& Puglielli 1970a,b) (Fig. 8). The only exception was found in arntely irradiated woody plants, scored two years after irradiation. They showed an equally close correlarton between ICV and exposure at various end points, but with tegiessions hoving shalliwit slopes $(-0.73$ as opposed to -1 in all other correlations) (Sparrow, Rogers \& Schwemer 1968) (Fig. y). No explanation has been found for this apparent anomaly, nor for the fact that woody plants are in general more sensitive than herbaceous plants of similar chromosomal size (Sparrow \& Sparrow 1965). These differences are apparent in Figure 10, which is a composite of regressions of exposure versus ICV for various end points, including whole-plant $D_{0}$ and $D_{q}$ (Underbrink \& Pond 197.6).

Since the slopes of regressions of $L D_{n}$ vs $I C V$ do not vary significantly from -1 (except as noted above), the product of exposure in $k R$ times $I C V$ in $\mu \mathrm{m}^{3}$ at any point on the regression will approach a constant, and will indicate the quantity of energy 
absorbed per average interphase chromosome at that end point. Thus for any end point the energy absorbed per chromosome is the same, regardless of differences in chromosome size, chromosome number, or exposure required to reach that end point.

Energy absorption per chromosome $(\mathrm{E} / \mathrm{Ch})$ is generally expressed in MeV, and may be summarized by the formula E/Ch = ICV $\times L D_{n} \times 60.2$, where 60.2 is the product of $34 \mathrm{eV}$ per ion pair (corrected from an earlier estimate of 32.5) times 1.77 ionizations per $\mu \mathrm{m}^{3}$ of wet tissue per $R$. This concept is discussed in greater detail by Sparrow (1962), Sparrow, Schairer \& Sparrow (1963), Sparrow \& Schwemer (1974) and Underbrink \& Pond (1976).

As a corollary to these findings, Sparrow, Underbrink \& Sparrow (1967) noted that, for a wide variety of organisme from viruses to higher plants and animals, a plot of $D_{0}$ against ICV (defined here as the volume of a chromosome, bacterial nucleoid or virus particle) resulted not in a single regression line but in a series of eight parallel regression lines, all with slope $=-1$ (one line later modified by Sparrow, Howard, Cowie, Schwemer \& Nauman 1975). Thus there are for these organisms eight different levels of energy absorption at $D_{0}$. They have been designated "radiotaxa", al though they are not entirely uniform with regard to conventional taxonomy. These groups are non-overlapping and have been shown to be valid by critical statistical evaluation (Kaufman \& Miller 1970). Although their significance is not understood, these groupings probably reflect structural and physiological parameters which result in particular levels of energy absorption at $D_{0}$.

It should be emphasized that, while ICV is the single most useful nuclear parameter in estimating radiosensitivity, it is a purely conceptual quantity, being simply an estimate of the volume of an average interphase chromosome. It does not take into account such factors as bimodality of chromosome size, nor does it allow for nucleoli, other nuclear components, or interchromosomal space; thus the true volume of a chromosome is always smaller than the calculated ICV. Conger (1970) has calculated that the fraction of ICV that is actual chromosomal volume is 0.17 to 0.18 . Nevertheless, ICV as it is defined here - that is, meristematic nuclear volume divided by somatic chromosome number has proven to be a highly useful, reasonably accurate (to within a factor of two) and easily-determined index of radiosensitivity. If the nuclear DNA content of a species is known, its ICV may be estimated by dividing 3C DNA per nucleus (in $\mathrm{pg}$ ) by chromosome number and multiplying by 15 , since $1 \mathrm{pg}$ of DNA is equivalent to about $15 \mu \mathrm{m}^{3}$ of nuclear or chromosomal volume (Baetcke, Sparrow, Nauman \& Schwemer 1967). Radiosensitivity of a previouslyuntested plant species may then be estimated from this figure. 
When earlier studies showed increased radioresistance in polyploids relative to their corresponding diploids, it was thought that this was a result of the protective effect of genetic redundancy. While this is probably true in cases of artificially-induced autopolyploidy where there has been little change in chromosome size or in genetic makeup, it was later realized that the increased resistance of polyploids was probably due mainly to their smaller chromosomal size relative to corresponding diploids, and that, in general, ICV was still the major determining factor in radiosensitivity (Sparrow, Sparrow, Thompson \& Schairer 1965; Ichikawa 1970).

There are special cases involving variation in chromosome number where the relationship is less clear, specifically haploidy and high levels of polyploidy. Conger, Sparrow, Schwemer \& Rlug (1979) have investigated the relactouship of ploidy level to sensitivity in 11 plant genera which together span a ploidy range of 1x to 22x. Despite a lack of inter- and intrageneric consistency, they confirmed the role of ICV as the major determinant of radiosensitivity at most ploidy levels. However, they found a considerably increased sensitivity in haploids and in plants with ploidy levels of $10 x$ or above. Their findings are summar ized and discussed by Underbrink \& Pond (1976).

Because of inconsistencies and contradictions both in published chromosome counts and in taxonomic attribution, it is always advisable to determine the actual chromosome number of a plant along with its nuclear volume or DNA content (see Appendix) when estimating the radiosensitivity of an untested plant.

\section{(d) Related factors}

Moiotic and mitotic cycle times have hepn shown to be related to nuclear and chromosome volume and to DNA content; and thus may be considered to be indirectly related to radiosensitivity. Underbrink \& Pond (1976) have plotted data on mitotic cycle time and on duration of the S period, taken from Van't Hof (1975), against ICVs estimated from DNA content, and found a definite positive correlation in both cases. A similar plot of meiotic cycle time, taken from Bennett (1972), against estimated ICV showed a much closer correlation (Underbrink \& Pond 1976). Thus, if cycle time is the only known nuclear parameter for a given plant, one of these plots can be used for a very rough estimate of ICV, which will in turn give a preliminary indication of where 
the particular plant would be likely to fall within the overall range of plant radiosensitivities.

5. Correlation of biological, environmental and experimental factors with radiosensitivity

Plant radiosensitivity may be altered or complicated by the effects of a great number of variables. The following list of such factors is modified from Sparrow, Schwemer \& Bottino (1973), after Gunckel \& Sparrow (1961).

Cytological and genetic factors

1. Chromosome number and ploidy level

2. Chromosome volume

3. Chromosomal DNA content

4. Length of mitotic cycle

5. Stage of mitotic or melotic cycle

6. Amount of heterochromatin

7. Number and position of centromeres

8. Genotype

9. Taxonomic group

Morphological and developmental factors

1. Type of cell or tissue

2. Stage of development or differentiation

3. Portion(s) of plant irradiated

4. Size of plant or depth of senstitive organs

5. Life form (woody, herbaceous)

6. Life span (annual, perennial)

7. Type of reproduction (sexual and/or vegetative)

Physiological factors

1. Age of plant or tissue

2. Metabolic rate

3. Growth rate

4. Stage of growth cycle (active, dormant)

5. Concentration of growth hormones

6. Concentration of protective or sensitizing substances

7. Water content

8. Nutritional state

9. Diseased tissue 
Experimental factors

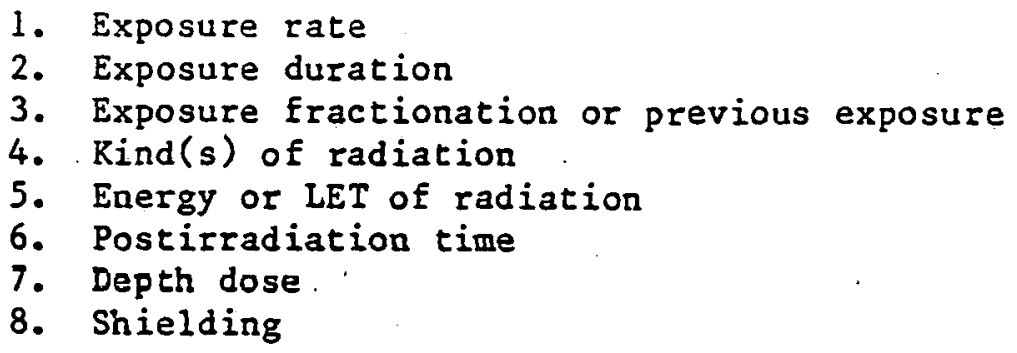

Environmental factors

1. Temperature; including diurnal variations

2. Light intensity

3. Day length

4. Relative humidity

5. Oxygen concentration

6. Wind velncity

7. Competition

8. Insects or other pests

9. Soil conditions - chemical composition, $\mathrm{pH}$, density, moisture content

10. Natural shielding (vegetation, snow, etc.)

Several of the factors listed have already been discussed, and the importance of some others is self-evident. For example, the adverse effects of disease, poor nutritional conditions, presence of insect pests, or environmental competition would all tend to increase the susceptibility of a plant to radiation damage.

With regard to the cytological factors listed, a higher degree of sensitivity would he expected, in general, to be associated with a lower chromosome number, lower ploidy level, larger chromosome volume and DNA content, much heterochromatin, slower mitotic or meiotio ayele time, normal his npprased to diffuse centromeres and acrocentric rather than metacentric chromosomes (Evans \& Sparrow 1961; Sparrow 1961; Sparrow, Cuany, Miksche \& Schairer 1961).

Plants within certain taxonomic groups tend to have predominantly very large or very small chromosomes, and so can be expected to have relatively high or low radiosensitivities. Examples of highly sensitive groups are the Pinaceae, particularly Pinus species, and indeed most of the conifers; the cyads; and many genera in the Liliaceae, notably Fritillaria, Lilium, Allium, and Trillium. At the other extreme, one could expect to find very small chromosomes and low radiosensitivities in the Crassulaceae, such as Sedum and Graptopetalum, and in the Cruciferae. One should be cautions, however, in generalizing on the basis of 
taxonomy, since within the genus Tradescantia, for example, there is a range in chromosome size and thus in sensitivity of at least 15-fold.

Taking the larger taxonomic groupings into consideration, the gymnosperms as a whole are much more sensitive than the woody angiosperms (Sparrow, Rogers \& Schwemer 1968). Among the herbaceous plants, taxonomic class (monocot or dicot), considered in combination with life span, could be useful in predicting probable relative sensitivity at the upper (more sensitive) end of the range. While distributions of dicots and monocots overlap in the region of low sensitivity, virtually all large-chromosome high-sensitivity plants studied (ICVs of $50 \mu \mathrm{m}^{3}$ or more, $\mathrm{LD}_{50}$ of $1.5 \mathrm{kR}$ or less) are monocots (data in Table 5). Similarly, annuals and perennials also overlap at the lower end of the sensitivity range, but all plants studied with ICVs of $35, \mathrm{um}^{3}$ or more ( $\mathrm{LD}_{50} \mathrm{~s}$ of less than $2.2 \mathrm{kR}$ ) are perennials (data in Table 5). Thus, if one wished to choose a highly-sensitive plant for radiation studies, a logical starting point would be the monocotyledonous perennials or gymosperms.

Many of the morphological, developmental and physiological factors listed above are discussed in some detail by Sparrow, Schwemmer \& Bottino (1971), and also by Sparrow \& Woodwell (1962), who deal with radiation responses at the population level. Some biochemical factors which affect plant radiosensitivity are 1 isted by Gunckel \& Sparrow (1961), and will not be enumerated here.

Woody and herbaceous plants respond similarly to irradiation in that there is a linear relationship between ICV and exposure at a given endpoint. However there are important differences in response which are presented visually in Figure 10. The regression lines for chronic exposures in both groups have the same slopes $(=-1)$ but different intercepts, with woodies being more sensitive for a given endpoint. With acute exposures, the woodies are again more sensitive, but with shallower slopes than those of the herbaceous species. No satisfactory explanation has been offered for the differences, but relevant data and discussion are presented by Sparrow, Rogers \& Schwemer (1968) and Sparrow, Schwenmer, Klug \& Puglielli $(1970 a, b)$.

These authors have also shown that the radiosensitivity of woody plants decreases during the dormant period. This is not unexpected, since it is also a time of lesser mitotic activity and decreased nuclear volume. Sparrow, Schwemmer, Klug \& Puglielli (1970a) found an active-to-dormant nuclear volume ratio of 1.54 , which agrees well with similar ratios found in earlier studies by Sparrow, Rogers \& Schwemer (1968) and Taylor (1966). 
Many herbaceous plants reproduce asexually as well as, or instead of, sexually. This factor tends to decrease their radiosensitivity, in that vegetative tissue is less sensitive than reproductive tissue (Underbrink \& Pond 1976). Also, many perennating organs, such as rhizomes, bulbs, tubers and stolons, are shielded by growing underground. Moreover, these organs generally undergo a period of dormancy when sensitivity is presumably decreased, as it is in dormant woody plants.

Among the most important of experimental variables are exposure rate and exposure duration. Generally, a lower rate and longer time for a given total exposure have a lesser effect than the same total exposure given for a shorter time at a higher rate. Also, dose fractionation usually reduces the effect of a given tocal exposure. These and other experimental variables are considered in greater detail by Sparrow (1961), Sparrow, Cuany, Miksche \& Schairer (1961) and Sparrow, Schwemer \& Bottino (1971). These authors also discuss various environmental variables which may affect radiosensitivity. The considerable effect of tempereture on radiooensitivity is discussed by Sparrow, Schwemer \& Bottino (1973). Thay note that an increase in temperature after. irradiation may reduce survival by as much as 50 percent, and will also result in a shorter period of elapsed time before plant death occurs. Conversely, decreased postirradiation temperature results in longer survival time, so that too-early scoring would give a false indication of radioresistance.

It is obvious that in determining or predicting plant radiosensitivity one must take into consideration the large number of relevant variables. Therefore one would be well-advised to consult the appropriate sources for more detailed information and discussion. of particular value for a general overview of existing work on plant radiosensitivity are the reviews by Sparrow, Sparrow, Thompson \& Schairer (1965); Sparrow, Schwemuer \& Bottino (1971); Sparrow \& Schwemmer (1974); and Underbrink \& Pond (1976).

\section{b. Aurichöe's nore}

Just prior to his untimely death, Dr. Arnold H. Sparrow had been asked to write this chapter. The present author, one of his long-time laboratory associates, is acting as his surrogate in this task. Nearly all of the body of data presented here was produced in his laboratory, through a prolonged community of effort. Countless colleagues, assistants and students have contributed, but the preponderance of data were generated by $h$ is regular staff, whose extraordinary loyalty assured continuity and consistency over the years. Therefore, since we were all cogs in the same wheel, it seems appropriate to acknowledge the contributions of his other long term associates, the more so since 
togather we put nearly 200 human-years of effort into Dr. Sparror's now-ended radiobiological research.

On the technical staff, Rhoda C. Sparrow, his wife, worked with him for 29 years, Virginia Pond 28 years, Lloyd A. Schairer 23 years, Anne F. Nauman 17 years, E. Eric Klug 14 years, Susan S. Schwemer 12 years, Richard C. Sautkul is 10 years, Marta M. Nawrocky 10 years; collaborators Dr. Alan G. Underbrink and Dr. Charles H. Naunan both 11 years; secretary Harriot Barry 14 years; and statistical consultant Keith $\mathrm{H}$. Thompson 14 years. 


\section{Referwnces}

1. Baetcke, K. P., Sparow, A. H., Nauman, C. H. and Schwemmer, S. S. 1967. The relationship of DNA content to nuclear and chromosome volumes and to radiosensitivity ( $L D_{50}$ ). Proceedings of the National Academy of Sciences, U.S.A., 58, 533-540.

2. Bennett, M. D. 1972. Nuclear DNA content and minimum generation time in herbaceous plants. Proceedings of the Royal Soclety of London B, 181, 109-135.

3. Bennett, M.D.' and Smith, J. B. 1976. Nuclear DNA amounts in anglosperms. Philosophical Transactions of the Royal Society of London B, 274, 227-274.

4. Butlluo, P. J. and Bores, R. J. 1973. Relative biological effectiveness (RBE) of beta-, gamma- and $x$-irradiatinn for seedling growth and survival in barley and somatic mutations in Tradescantia. (unpublished).

5. Bottino, P. J. and Sparrow, A. H . 1971a. Comparison of the effects of simulated fallout decay and constant exposure-rate gama-ray treatments on the susvival and yleld of wheat and oats. Radiation Botany 11, 405-410.

6. Bottino, P. J. and Sparrow, A. H. 1971b. The effects of exposure time and rate on the survival and yfeld of lettuce, barley and wheat. Radiat1on Botany 11, 147-156.

7. Bowen, H. J. M. 1962. Radiosensitivity in higher plants, and correlations with cell weight and DNA content. Radiation Botany 1, 223-228.

8. Bowen, H. J. M. and Simith, S. R. 1939. Effecl of gama-radiation on weeds. Nature 183, 907.

9. Caldecott, R. S. 1961. Seedling helght, oxygen availability, storage and temperature: their relation to radiation-induced genetic and seedling injury in barley. Effects of Ionizing Radiations on Seeds, International Atomlc Energy Agency, Vienna.

10. Capella, J. A. and Conger, A. D. 1967. Radiosensitivity and interphase chromosome volume in the gymnosperms. Radiation Botany 7, 137-149.

11. Conger, A. D. 1970. The relation of interphase chromosome volume (ICV) to an estimated 'actual chromosome volume'. International Journal of Radiation Biology 17, 381-384. 
12. Conger, A. D., Sparrow, A. H., Schwemmer, S. S., and Klug, E. E. 1979. Relation of nuclear volume and radiosensitivity to ploidy level (haploid to 22-ploid) in higher plants and yeast. Radiation Research, in preparation.

13. Darlington, C. D. and La Cour, L. F. 1975. The Handling of Chromosomes, 6th edition. George Allen and Unwin Ltd., New York.

14. Donini, B., Sparrow, A. H., Schairer, L. A. and Sparrow, R. C. 1967. The relative biological efficiency of gama rays and fission neutrons in plant species with different nuclear and chromosome volumes. Radiation Resarch 32, 692-705.

15. El-Lakany, M. H., and Sziklai, O. 1970a. Effects of gams-irradiation on some western conifers. Radiation Botany $10,411-420$.

16. E1-Lakany, M. H., and Sziklai, 0. 1970b. Variation in nuclear characteristics in selected western conifers and its relation to radiosensitivity. Radiation Botany 10,421-427.

17. Evans, H. J. and Sparrow, A. H. 1961. Nuclear factors affecting radiosensitivity. II. Dependence on nuclear and chomosome structure and organization. Brookhaven Symposia in Biology 14, 101-127.

18. Fujii, T. and Matsumura, S. 1958. Radiosensitivity in plants. I. Determination of LD-50 in cultivated plants. (Preliminary report). Japanese Journal of Genetics 33, 389-397.

19. Gómez-Campo, C. and Delgado, L. 1964. Radioresistance in crucifers. Radiation Botany 4, 479-483.

20. Gunckel, J. E. and Sparrow, A. H. 1961. Ionizing radiations: biochemical, physiological and morphological aspects of their effects on plants. In: Encyclopedia of Plant Physiology, Vol. 16, pp. 555-611.

21. Gustaffson, A. and von Wettstein, D. 1958. Mutationen und Mutationszüchtung. Handbuch der Pflanzenzuchtung 1, 612-699.

22. Ichikawa, S. 1970. Polyploidy and radiosensitivity in higher plants. Gamma Field Symposia 9, 1-17.

23. Johnstone, G. R. and Klepinger, F. W. 1967. The effects of gama radiation on germination and seedling development of Yucca brevifolia Engelm. Radiation Botany 7, 385-388.

24. Rautran; G. E. and Miller, M. W. 1970. A statistical evaluation of Sparrow et al.' 's relationship of. $D_{0}$ to chromosome volume. Radiation Research 42, 181-187. 
25. Kraus, M. P. 1969. Resistance of blue-green algae to ${ }^{60} \mathrm{Co}$ gamma radiation. Radiation Botany 9, 431-489.

26. Miksche, J. P. and Rudolph, T. D. 1968. Use of nuclear varlables to investigate radiosensitivity of gymnosperm seed. Radiation Botany 8, 187-192.

27. Miller, M. W. 1970. The radiosensitivity of three pairs of diploid and tetraploid plant species: correlation between nuclear and chromosomal volume, Roentgen exposure and energy absorption per chromosome. Radiation Botany 10, 273-279.

28. M1llex, M. W. and Sparrow, A. H. 1965. The radiosengitfvity of thalli of Marchant1a polymorpha L. to acute gamma Irradiation. Radiation Botany 5, 567-580.

29. Miller, M. W., Sparrow, A. H. and Rogers, A. F. 1965. The radiosensitivity of gevwat of Marchantia polymorpha L. to aeute gamma irradiation. The Bryolugist $68,31-47$.

30. Nirula, S. 1963. Studies on some nuclear factors controlling radiation sensitivity and the Induced mutation rate in Eu-Para-Sorghum specles. Radiation Botany 3, 351-361.

31. Osborne, T. S. and Constantin, M. J. 1966. Sensitfolty to ionizlng radiation: dormant seeds. In: Environmental Blology, P. L. Altman and D. S. Dittmer, eds., Federation of American Societies for Experimental Blology, Bethesda, Maryland, U.S.A., Pp. 183-190.

32. Osborne, T. S. and Lunden, A. 0. 1961. The cooperative plant and seed Irradiation program of the University of Tennessee. International Journal of Applied Radiation and Isotopes 10, 198-209.

33. Osborne, T. S. and Lunden, A. 0. 1964. Seed radiosensitivity: a new constant? Science 145, 710-711.

34. Posner, B. B. and Sparrow, A. H. 1964. Survival of Chlorella and Chlamydomonas after acute and chronic gamma radtation. Radiat1on Botany 4, 253-257.

35. Price. H. J., Sparrow, A. H. and Nauman, A. F. 1973. Correlations between nuclear volume, cell volume and DNA content in mertstematic cells of herbaceous anglosperins. Experientia 29, 1028-1029.

36. Rudolph, T. D. 1971. Gymnosperm seedling sensitivity to gamma radiation: its relation to seed radiosensitivity and nuclear varlables. Radiation Botany 11, 45-51. 
37. Pudolph, T. D. and Miksche, J. P. 1970. The relative sensitivity of the soaked seeds of nine gymnosperm species to gamma radiation. Radiation Botany 10, 401-409.

38. Sass, J. E. 1958. Botanical Microtechnique, 3rd edition. Iowa State Universicy Press, Ames, Iowa, U.S.A.

39. Sparrow, A. H. 1960. Uses of large sources of lonizing radiation in botanical research and some possible practical applications. In: Large Radiation Sources in Industry, Vol. 2. International Atomic Energy Agency, Vienna. pp. 195-219.

40. Sparrow, A. H. 1961. Types of lonizing radlation and their cytogenetic effects. In: Mutation and Plant Breeding, Publ. no. 891, National Academy of Sclences - National Research Counc11, Washington, D.C., U.S.A., pp. 55-119.

41. Sparrow, A. B. 1962. The role of the cell nucleus in determining radiosensitivity. Brookhaven Lecture Series No. 17, Brookhaven National Laboratory, Upton, New York, U.S.A. BNL $766(T-287) .29$ pp.

42. Sparrow, A. H. 1965a. Comparisons of the tolerances of higher Flant specles to acute and chronic exposures of ionfing radiation. Japanese Journal of Genetics 40, Supplement, 12-37.

43. Sparros, A. H. 1965b. Relationship between chromosome volume and radiation sensitivity in plant cells. In: Cellular Radiation Biology. The Williams and Wilkins Company, Baltimore, Maryland, U.S.A., pp. 199-222.

44. Sparrow, A. H. 1966. Research uses of the gamma field and Ielated radiation facilities at Brookhaven National Laboratory. Radiation Botany 6, 377-405.

45. Sparrow, A. H., Baetcke, K. P., Shaver, D. L. and Pond, V. 1968. The relationship of mutation rate per roentgen to DNA content per chromosome and to intarphase chromosome volume. Genetics 59, 65-78.

46. Sparrow, A. H., Binnlngton, J. P. and Pond, V. 1958. Bibliography on the effects of ionizing radiations on plants, 1896-1955. Brookhaven National Laboratory, Upton, New York, J.S.A., BNL 504 (L-103), 222 PP.

47. Sparrow, A. H. and Christensen, E. 1953. Tolerance of certain higher plants to chronic exposure to gamma radiation from Cobalt-60. Scieace 118, 697-698. 
48. Sparrow, A. H., Cuany, R. L., Miksche, J. P. and Schairer, L. A. 1961. Some factors affecting the responses of plants to acute and chronic radiation exposures. Radiation Botany 1 , 10-34.

49. Sparrow, A. H. and Evans, H. J. 1961. Nuclear factors affecting radiosensitivity. I. The influence of nuclear size and structure, chromosome complement, and DNA cuntent. Brookhaven Symposia in Biology 14, 76-100.

50. Sparrow, A. H., Floyd, B. and Bottino, P. J. 1970. Effects of simulated radioactive fallout buildup and decay on survival and yield of lettuce, maize, radish, squash and tomato. Radiation Botany 10, 445-455.

51. Sparrow, A. H. and Gunckel, J. E. 1956. The effects on plants of chronic exposure to gama radiation from radiocobalt. Proceedings of the International Conference on Lhe Peaceful Uses of Atomic Energy 12, 52-59.

52. Sparrow, A. H., Howard, A., Cowie, F. G., Schwemer, S. S. and Nauman, A. F. 1975. Chromosomes and cellular radiosensitivity. IV. A new radiotaxon represented by the ferns. International Journal of Radiation Biology 27, 343-354.

53. Sparrow, A. H. and Konzak, C. F. 1958. The use of ionizing radiation in plant breding: accomplishments and prospects. In: Camellia Culture, E. C. Tourje, ed. The Macmillan Company, New York, PP. 425-452.

54. Sparrow, A. H. and Miksche, J. P. 1961. Correlation of nuclear volume and DNA content with higher plant tolerance to chronic radiation. Science $134,282-283$.

55. Sparrow, A. H. and Nauman, A, F. 1973. Fịnlutionary changes in genome and chromosome sizes and in DNA content in the grasses. Brookhaven Symposia in Biology 25, 367-389.

56. Sparrow, A. H. and Nauman, A. F. 1976. Evolution of genome size by DNA doublings. Science 192, 524-529.

57. Sparrow, A. H., Price, H. J. and Underbrink, A. G. 1972. A survey of DNA content per cell and per chromosome of prokaryotic and eukaryotic organisms: some evolutionary considerations. Brookhaven Symposia in Biology 23, 451-494.

58. Sparrow, A. H. and Puglielli, L. 1969. Effects of simulated radioactive fallout decay on growth and yield of cabbage, maize, peas and radish. Radiation Botany 9, 77-92. 
59. Sparrow, A. H., Rogers, A. F. and Schwemer, S. S. 1968. Radiosensitivity studies with woody plants. I. Acute gama irradiation survival data for 28 species and predictions for 190 species. Radiation Botany 8, 149-186.

60. Sparrow, A. H., Schairer, L. A. and Sparrow, R. C. 1963. Relationship between nuclear volumes, chromosome numbers, and relative radiosensitivities. Science 141, 163-166.

61. Sparrow, A. H. and Schwemer, S. S. 1974. Correlations between nuclear characteristics, growth inhibition, and survival-curve parameters ( $L D_{n}$, whole $p l a n t D_{0}$ and $D_{q}$ ) for whole-plant acute gama-irradiation of herbaceous species. International Journal of Radiation Biology 25, 565-581.

62. Sparrow, A. H., Schwemer, S. S. and Botrino, P. J. 1971. The effects of external ganma radiation from radioactive fallout on plants with special reference to crop production. Radiation Botany 11, 85-118.

63. Sparrow, A. H., Schwemer, S. S. and Bottino, P. J. 1973. Influence of dose, environmental conditions and nuclear volume on survival times in several gamma-irradiated plant species. International Journal of Radiation Biology 24, 377-388.

64. Sparrow, A. H., Schwemer, S. S., Rlug, E. E. and Puglielli, L. 1970a. Radiosensitivity studies with woody plants. II. Survival data for 13 species irradiated chronically for up to 8 years. Radiation Research 44, 154-177.

65. Sparrow, A. H., Schwemer, S. S., Klug, E. E. and Puglielli, L. 1970b. Woody plants: changes in survival in response to long-term (8 years) chronic gamma irradiation. Science 169, 1082-1084.

66. Sparrow, A. H., Sparrow, R. C., Thompson, K. H. and Schairer, L. A. 1965. The use of nuclear and chromosomal variables in determining and predicting radiosensitivities. Radiation Botany 5, Supplement, 101-132.

67. Sparrow, A. H., Underbrink, A. G. and Rossi, H. H. 1972. Mutations induced in Tradescantia by small doses of $x$-rays and neutrons: analys is of dose-response curves. Science 176, 916-918.

68. Sparrow, A. H., Underbrink, A. G. and Sparrow, R. C. 1967. Chromosomes and cellular radiosensitivity. I. The relationship of $D_{0}$ to chromosome volume and complexity in seventy-nine different organisms. Radiation Research 32, $915-945$.

69. Sparrow, A. H. and Woodwell, G. M. 1962. Prediction of sensitivity of plants to chronic gama irradiation. Radiation Botany 2, 9-26. 
70. Sparrow, R. C. and Sparrow, A. H. 1965. Relative radiosensitivities of woody and herbaceous spermatophytes. Sclence 147, 1499-1451.

71. Stairs, G. R. 1963. Acute gama irradiation of Quercus seed. Silvae Genetica 12, 192-200.

72. Taylor, F. G., Jr. 1966. Predicted seasonal radiosensitivity of southern tree species. Radiation Botany 6, 307-311.

73. Underbrink, A. G. and Pond, V. 1976. Cytological factors and their predictive role in comparative radjosensitiviry: a genelal sumary. Current Topics in Radiation Research Quarterly 11, 251-306.

74. Underbrink, A. G., Schatrer, L. A. nd Sparrow, A. H. 1973. Tradescantia stamen halroi a radioblological test system applicable to chemical mutagcnesis. In: Chemlcal mutagens: Principles and methods for their detection, Vol. 3, A. Hollaender, ed. Plenum Press, New York, pp. 171-207.

75. Underbrink, A. G., Sparrow, A. H., Pond, V., Takahashi, C. S. and Rappas, A. 1973. Radiation-induced pollen abortion in several commelinaceous taxa: its relation to chromosomal parameters. Radiation Botany 13, 215-227.

76. U. S. National Bureau of Standards Handbook 85. 1962. Physical Aspects of Irradiation. ICRU Report 10b.

77. Van't Hof, J. 1975. The duration of chromosomal DNA synthesis, of the mitotic cycle, and of melosis of higher plants. In: Handbook of Genettes, VoI. 2, R. C. King, ed. Plenum Press, New York, pp. 363-377.

78. Woodwell, G. M: aul Gannuez, 'M. P. 1967. Effects of chronic gamma irradiation on lichen communities of a forest. American Journal of Botany 54, 1210-1215.

79. Woodwell, G. M. and Rebuck, A. L. 1967. Effects of chronic gamma radiation on the structure and diversity of an oak-pine forest. Ecological Monographs 37, 53-69.

80. Woodwell, G. M. and Sparrow, A. H. 1963. Predicted and observed effects of chronic gama radiation on a near-climax forest ecosystem. Radiation Botany 3, 231-237.

81. Woodwell, G. M. and Sparrow, A. H. 1965. Effects of ionizing radiation on ecological systems. In: Ecological Effects of Nuclear War, G. M. Woodwell, ed. BNL $917(C-43)$, Brookhaven National Laboratory, Upton, New York, U.S.A. pp. 20-38. 
82. Woodwel1, G. M. and Whittaker, R. H. 1968. Effects of chronic gamma irradiation on plant comunitles. Quarterly Review of Blology, 43 42-55.

83. Yamagata, H., Kowyama, Y. and Syakudo, K. 1969.

Radiosensitivity and polyploidy in some non-tuber bearing

Solanum species. Radiation Botany 9, 509-521.

84. Yamakawa, K. and Sparrow, A. H. 1965. Correlation of interphase chromosome volume and reduction of viable seed set by chronic irradiation of 21 cultivated plants durlag reproductive stages. Radiation Botany 5, 557-566.

85. Yamakawa, K. and Sparrow, A. H. 1966. The correlation of Interphase chromosome volume with pollen abortion induced by chronic gama irradiation. Radiation Botany 6, 21-38. 


\section{Appendix}

(a) Methods for determining nuclear factors used in prediction of plant radiosensitivity

Although chromosome volume is the basis for predictinns of radiosensitivities, the parameters actually determined in the laboratory are nuclear volume and chromosome number, ICV being calculated by dividing the former by the latter. Methods for nuclear volume determination have been published previously (Sparrow, Rogers \& Schwemer 1968) but will be presented here in greater detail.

From 3 to 12 meristems are fixed in Craf III, a modified Nawashin fixative (see Sass 1958), as soon as possible after removal from the plant, keeping the plant material moist if delay before fixation is unavoidable. Root tips, about $5 \mathrm{~mm}$ in length, are best obtained from potted plants or from rooted cuttings. Shoot tips are dissected down by cutting or peeling away bud scales and leaf primordia until the apex is nearly exposed. This triming down is especially important in buds which are waxy, resinous, hairy, fibrous or woody. Woody plants, particularly the resinous gymosperms, must have all bud scales removed to assure proper peretration of the fixative. After dissection the shoot tip should not exceed about 5 in length and 2-3 in thickness. Samples are gently evacuated as soon as possible after fixation, until they sink in the fixative. If buds have a waxy coating which inhibits fixative penetration, a very small drop of 1 iquid dotcrgent will usually cause them to sink. Samples should be fixed overaight, but may be left in the fixative almost indefinitely.

Great care must be taken to omit flower buds or buds which have begun floral transition. This may be evidenced by elongation of internodes or by changes in the shape of the apex as observet mloroocopically. It is preterable to take shoots from seedlings after development of their second true leaves; or from activelygrowing mature plants.

Dehydration is accomplished through an ethanol and tertiary butyl alcohol (TBA) series, as described by Sass (1958); with dry safranin added to the last ethanol-TBA mixture as a pre-stain to aid in tissue orientation during embedding and sectioning. Samples are embedded in paraffin with a $56-58^{\circ} \mathrm{C}$ melting point. Cardboard pillboxes are convenient for embedding and provide a uniformly flat surface for precise alignment of samples.

Sectioning is done longitudinally at $8 \mu \mathrm{m}$ unless plants are known to have very large or very small nuclei, when $10 \mu \mathrm{m}$ or $6 \mu \mathrm{m}$ would be more appropriate. Disposable microtome knives have been found to be quite satisfactory, as they are usable for a considerable number of samples, and they eliminate almost entirely the problem of static electricity. Sections are mounted serially 
on slides which have been "subbed" by coating with a thin layer of gelatine (see Darlington \& La Cour 1975), stained with safranin and fast green, and mounted in Permount.

In each of at least three samples, median longitudinal sections of the apex are located. Ten interphase nuclei are measured from the outer layer of the shoot apex, excluding the flanks where differentlation is occurring. In roots, cells are measured in the center of the meristematic region. In selecting nuclel to be measured, one should avoid those which are disproportlonately large and thus may. be in 62 with a $4 \mathrm{C}$. DNA amount. Using an ocular micrometer at $800 \mathrm{x}$ magnification, measurements are made in two perpendicular diameters, using major and minor axes where the nucleus deviates from a sphere. These measurements are converted to microns and averaged, and volumes are computed for each nucleus using the formula $v=d^{3} / 6$ where $d=$ the mean diameter. It has been determined that small deviations from a spherical shape do not result in significantly different volumes when applying this formula rather than the formula for a prolate spheroid. Volumes of at least 30 nuclel are averaged for each determination. If dormant woody plants must be used, the nuclear volume should be multiplied by 1.5 to compensate for seasonal varlation in nuclear size (see text).

Chromosome numbers are determined from root tips, al though in a few cases it has been necessary to use developing leaves or actively-growing shoot tips. Samples are pre-treated in a saturated solution of $\alpha$-bromonaphthalene for $3 \mathrm{hr}$ to arrest cells in metaphase, hydrolyzed for $12 \mathrm{~min}$ in $1 \mathrm{~N} \mathrm{HCl}$ at $60^{\circ} \mathrm{C}$, stained by the Feulgen leuco-basic fuchsin method (see Darlington \& La Cour 1975) for about one hour, and squashed. Slides are made permanent using the Conger-Fairchild quick-freezing method (Darlington \& La Cour 1975) and mounted in Euparal.

\section{(b) Glossary}

Absorbed dose - The quantity of energy 1mparted to a unit mass of material exposed to lonizing radiation, expressed in rad.

Acute exposure - A radiation exposure of relatively short duration (minutes to hours), usually at a relatively high exposure rate. Not clearly distingulshed from chronic exposure $(q \cdot \nabla \cdot)$, but sometimes considered to have a duration of no more than one mitotic cycle.

Basic number - the number of chromosomes in a single chromosome set, generally the lowest known haploid number in a serles within a given taxon. Indicated by $x$ (a diploid species is $2 \underline{x}$, a tetraploid 4x, et. seq.). See $\underline{\text { n. }}$

Chronic exposure - A radiation exposure of relatively long duration (days to weeks or years) at a relatively low exposure rate. See acute exposure. 
$D_{0}$ - The radiation dose that, on the exponential portion of a survival curve, reduces survival by $63 \%$. Generally used only for single-cell systems, but see Sparrow \& Schwemner (1974) for whole-plant $D_{0}$. Indicates the dose necessary to produce an average of one hit per target.

$D_{q}$ - A measure of shoulder width on a survival curve. The point at which the exponential portion of the curve, extrapolated upwards, intersects $100 \%$ survival.

Dose - See absorbed dose; exposure.

Dose rate - Energy absorption per unit of time, expressed in rad. often used inaccurately to indicate exposure rate.

Energy absorption per chromosome (E/Ch) - A calculated quantity based on $34 \mathrm{eV}$ per ion pair (corrected from the earlier estimate of $32.5 \mathrm{eV}$ ) and 1.77 ionizations per $\mathrm{km}^{3}$ of wet tissue per R. It may be expressed by the formula $E / C h=I C V \times L D_{n} \times 60.2$, where $I C V=$ chromosomal volume in $\mu \mathrm{m}^{3}, \mathrm{LD}_{\mathrm{n}}=$ exposure in $\mathrm{R}$ required for a given end point, and $60.2=34 \mathrm{eV} \times 1.77$ ionizations per unit volume per R.

Exposure - A measure of $X$ or gama radiation based upon its ability to produce ionizations in air, expressed in $R$.

Exposure rate - the accumulation of $X$ or gama rays delivered in a unit of time, expressed as $\mathrm{R} / \mathrm{min}, \mathrm{R} / \mathrm{hr}$, etc.

FDS - Fallout decay simulation. See text.

Genome - A single basic chromosome complement. The number of chromosomes in a genome is determined by dividing the somatic chromosome number by ploidy level.

Genome volume (GV) - The volume of a single genome for a given species, expressed in $\mu^{3}$. Estimated by dividing nuclear volume by ploidy level.

ICV - Average interphase chromosome volume, expressed in $\mu^{3}$. A conceptual rather than an actual value, it is estimated by dividing meristematic nuclear volume by somatic chromosome number, assuming all chromosomes in a complement to be the same size.

Ionizing radiations- Radiations which have the ability to produce ionizations (ions pairs) when they interact with matter. They may be electro-magnetic ( $X$ rays, gama rays) or particulate (alpha or beta particles, neutrons, protons, electrons). Oltra-violet rays are ionizing at only a few wavelengths, so are considered to be nonionizing.

$L D_{n}$ - The exposure required to reduce plant survival by $n$ percent from control values, generally expressed in $R$. 
n- The gametic or haploid chromosome number of a species, regardless of basic number. The somatic number is $2 \underline{n}$, regardless of ploidy level.

Nuclear volume - As used here, the average volume of nuclei measured from histological preparations of either the shoot or root meristem, expressed in $\mu^{3}$.

$R$ (Roentgen) - That quantity of $X$ or gamma radiation such that the associated corpuscular emissions for $0.001293 \mathrm{~g}$ of air produces, in air, ions carrying 1 esu of electricity of either sign. May also be defined as the quantity of $X$ or gamma radiation that produces $2.082 \times 10^{9}$ ion pairs per ce of air at $0^{\circ} \mathrm{C}$ and $760 \mathrm{~mm} \mathrm{Hg}$. The energy dissipated by $1 R$ is abut 86.9 ergs per $g$ of air.

rad - Radiation absorbed dose. The absorbed dose of any ionizing radiation that is accompanied by the liberation of 100 ergs of energy per $g$ of absorbing material. 
Figure Legends

n Fig. 1. Relationship of 3C DNA content to nuclear volume of 123 species of herbaceous higher plants. Correlation coefficlent = 0.893. DNA values from Bennett \& Smith (1976).

Fig. 2. Survival curve, showing method of determining $L D_{n}$, $D_{0},(=\infty-)$ and $D_{q}\left(C_{-}\right)$. See rext for detailed explanation.

Fig. 3. Relationship of exposure for whole-plant $D_{0}$ ( $D_{0} w \cdot p$. and whole-plant $D_{q}\left(D_{q} w \cdot p_{.}\right)$to interphase chromosome volume and estimated DNA per chromosome in 12 spectes of herbaceous plants. Slopes $=-1$. Adapted from Sparrow \& Schwemer (1974).

Fig. 4. Relationship of DNA content per cell to nuclear volume (a) and of DNA content per chromosome to interphase chromosome volume (b) for 30 specles of herbaceous plants. Slopes $=+1$. Adapted from Baetcke, Sparrow, Nauman Schwemer (1967).

Fig. 5. Relationship of LDso exposure to DNA per chromosome (a) and to interphase chromosome volume (b) for 10 species of herbaceous plants. Slopes $=-1$. Adapted from Baetcke, Sparrow, Nauman \& Schwemmer (1267).

F1g. 6. Composite of regressions of exposure required to produce $L D_{10}, L D_{50}, L D_{90}$ and $L D_{100}$ plotted agafnst interphase chromosome volume and estimated DNA per chromosome for acute (16-hr) exposures of 32 specles of herbaceous plants to gamma irradiation. All slopes $=-1$. Adapted from Sparrow \& Schwemer (1974).

Fig. 7. Relationship of daily chronic exposure in $R$ to interphase chromosome volume and estimated DNA per chromosome for 4 end points for herbaceous plant species. All slopes $=-1$. Adapted from Yamakawa \& Sparrow (1965).

Fig - 8. Composite of regressions of chroalc exposures (average $R /$ day and accumulated $k R$ for $3-y r$ exposures) required to produce various end points in woody plants plotted against interphase chromosome volume and estimated DNA per chromosome. Slight (SLGI) and severe (SGI) growth inhibition data (dashed lines) are for $1-y r$ exposures. All slopes $=-1$. Adapted from Sparrow, Schwemer, Klug \& Pugliell1 (1970a).

Fig. 9. Composite of regressions of acute exposure required to produce $L D_{10}, L D_{50}, L D_{90}$ and $L D_{100}$ in woody plants plotted against interphase chromosome volume and estimated DNA per chromosome. All slopes adjusted to mean of -0.73 . Adapted from Sparrow, Rogers \& Schwemer (1968).

Fig: 10. Composite of regressions of exposure (chronic, acute and accumulated) plotted against interphase chromosone volume and estimated DNA per chromosome for various survival end points. AlI slopes $=-1$ except for the two regressions for acutely-irradiated woody spectes. Adapted from Underbrink \& Pond (1974). 


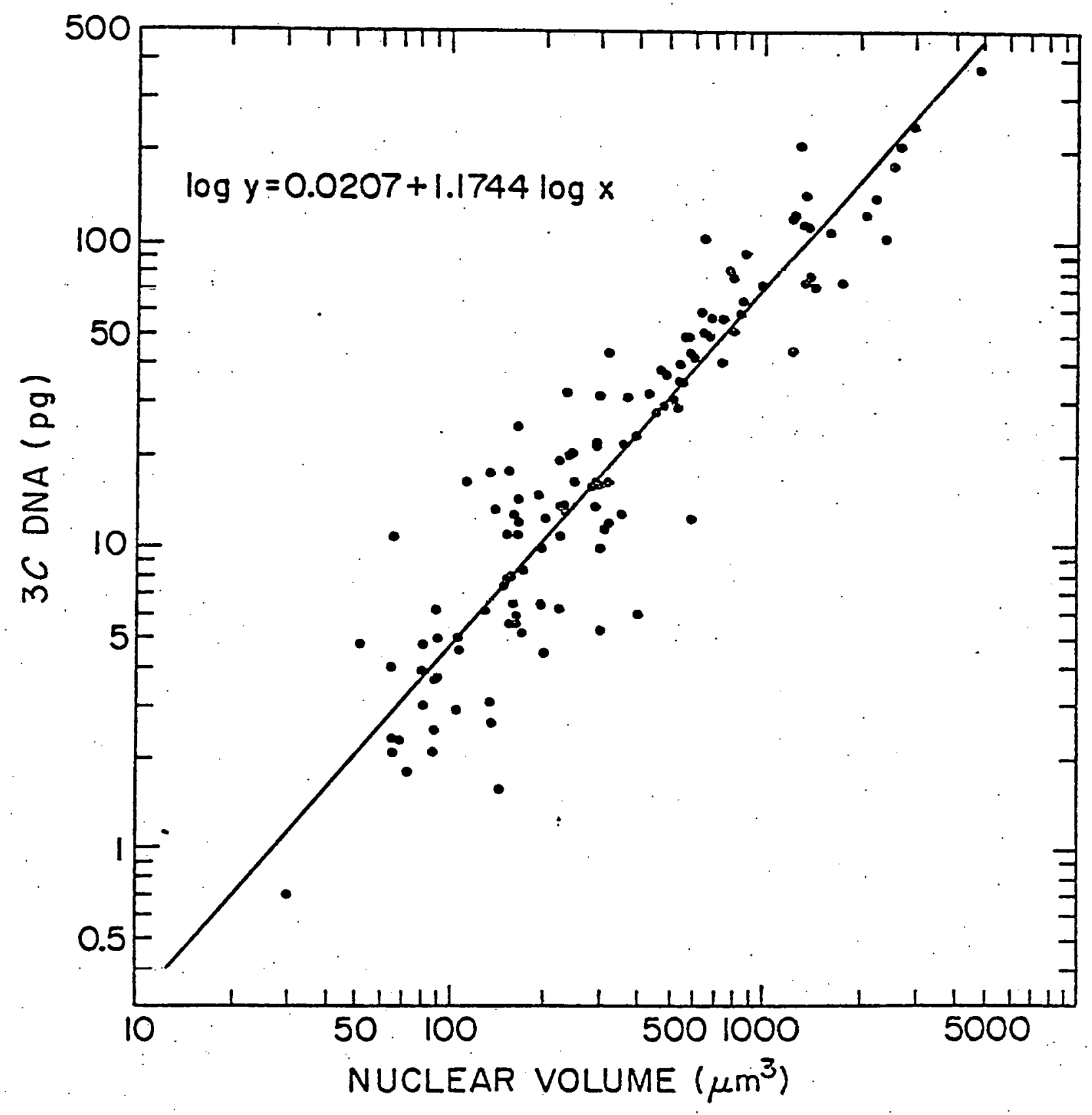

Fig. 1 


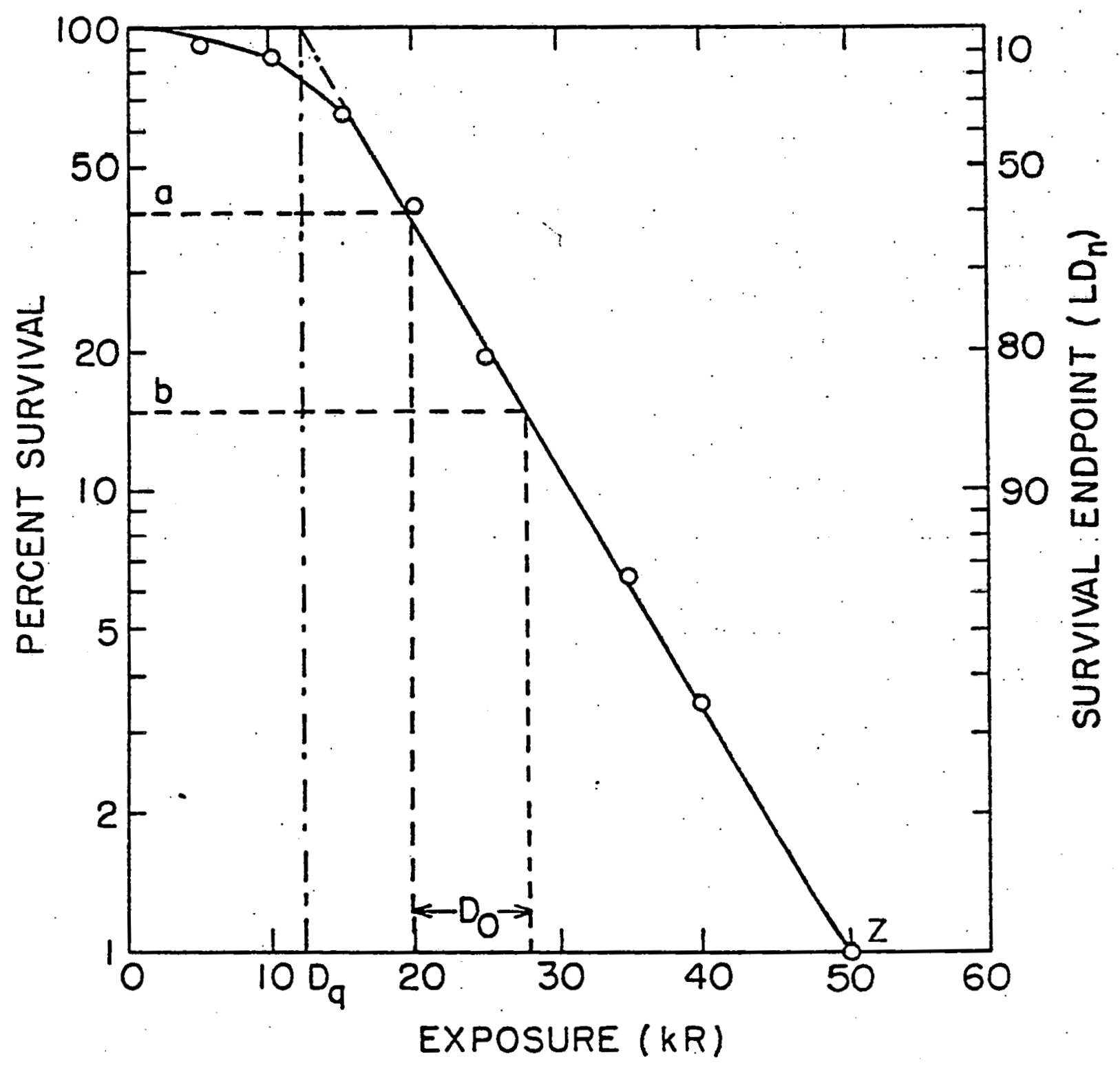

Fig. 2 


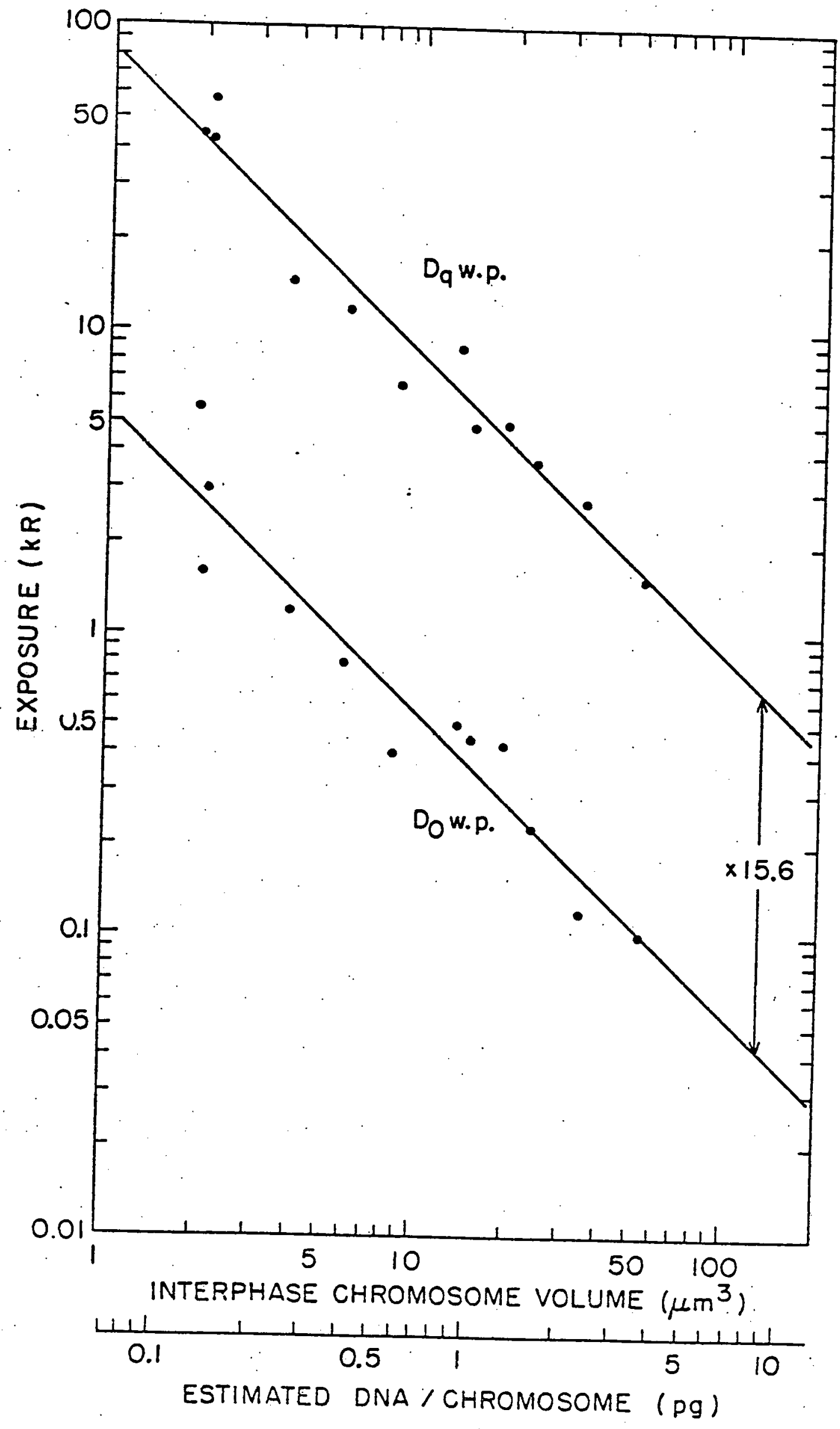

Fig. 3 


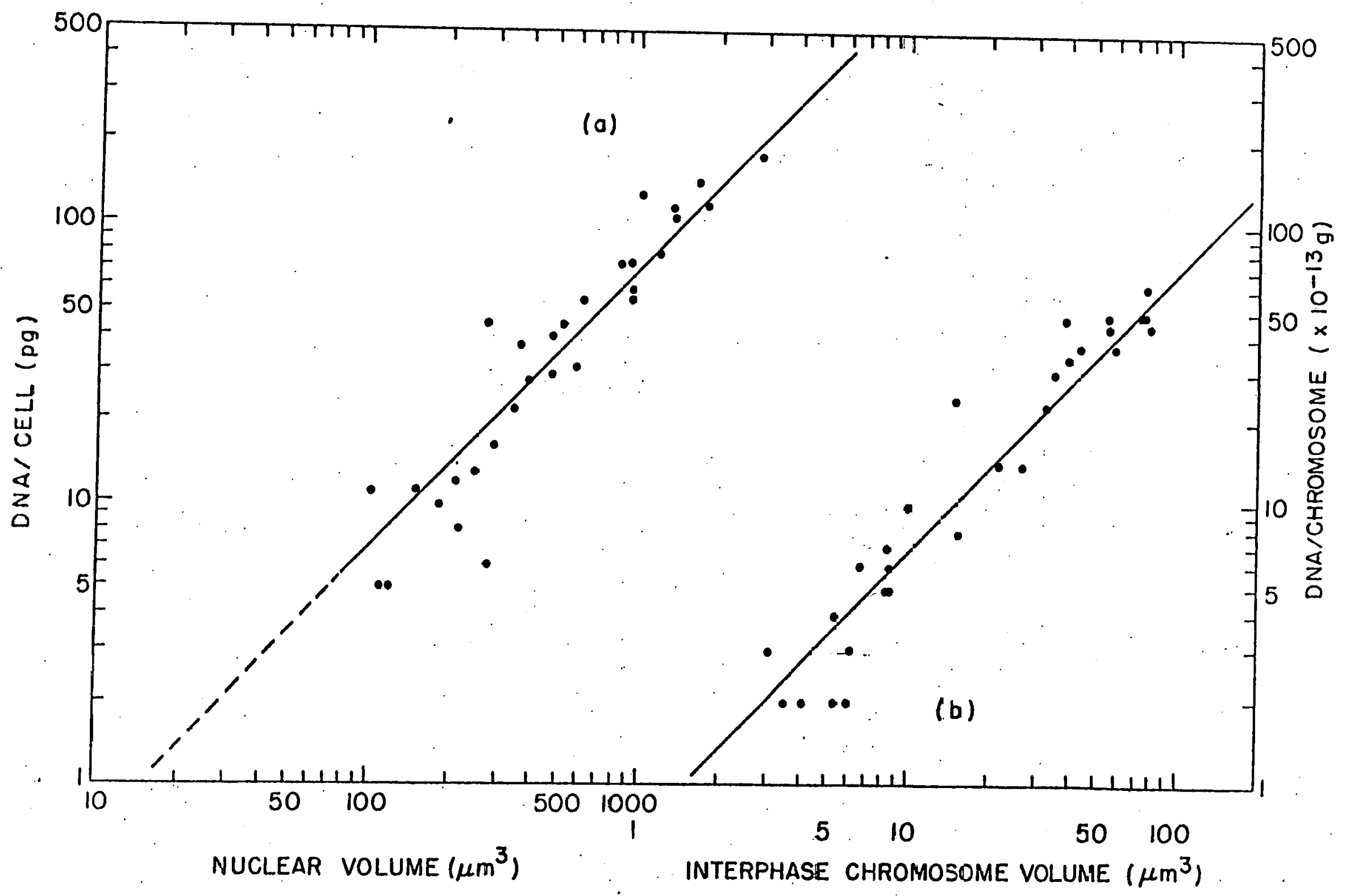




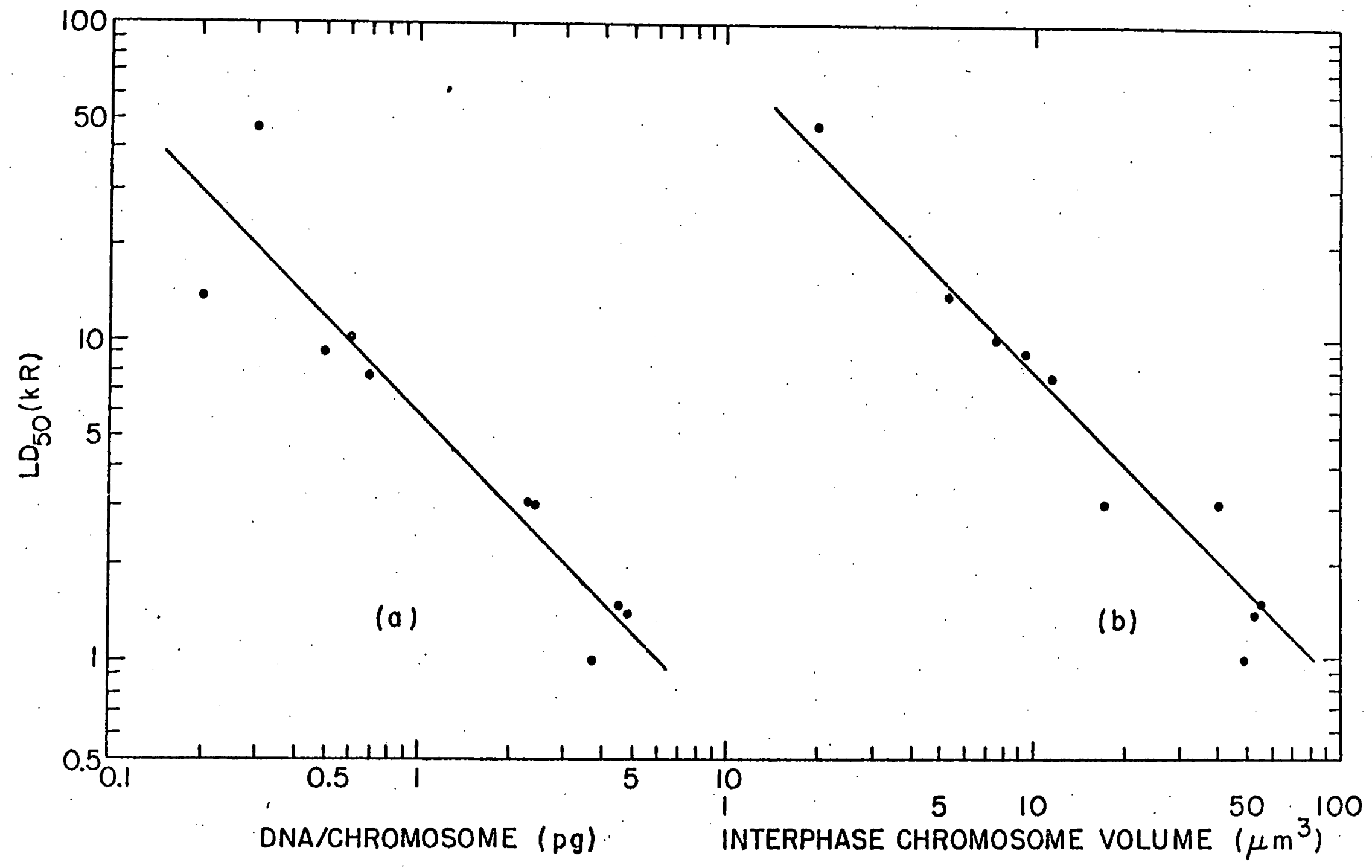

Fig. 5 


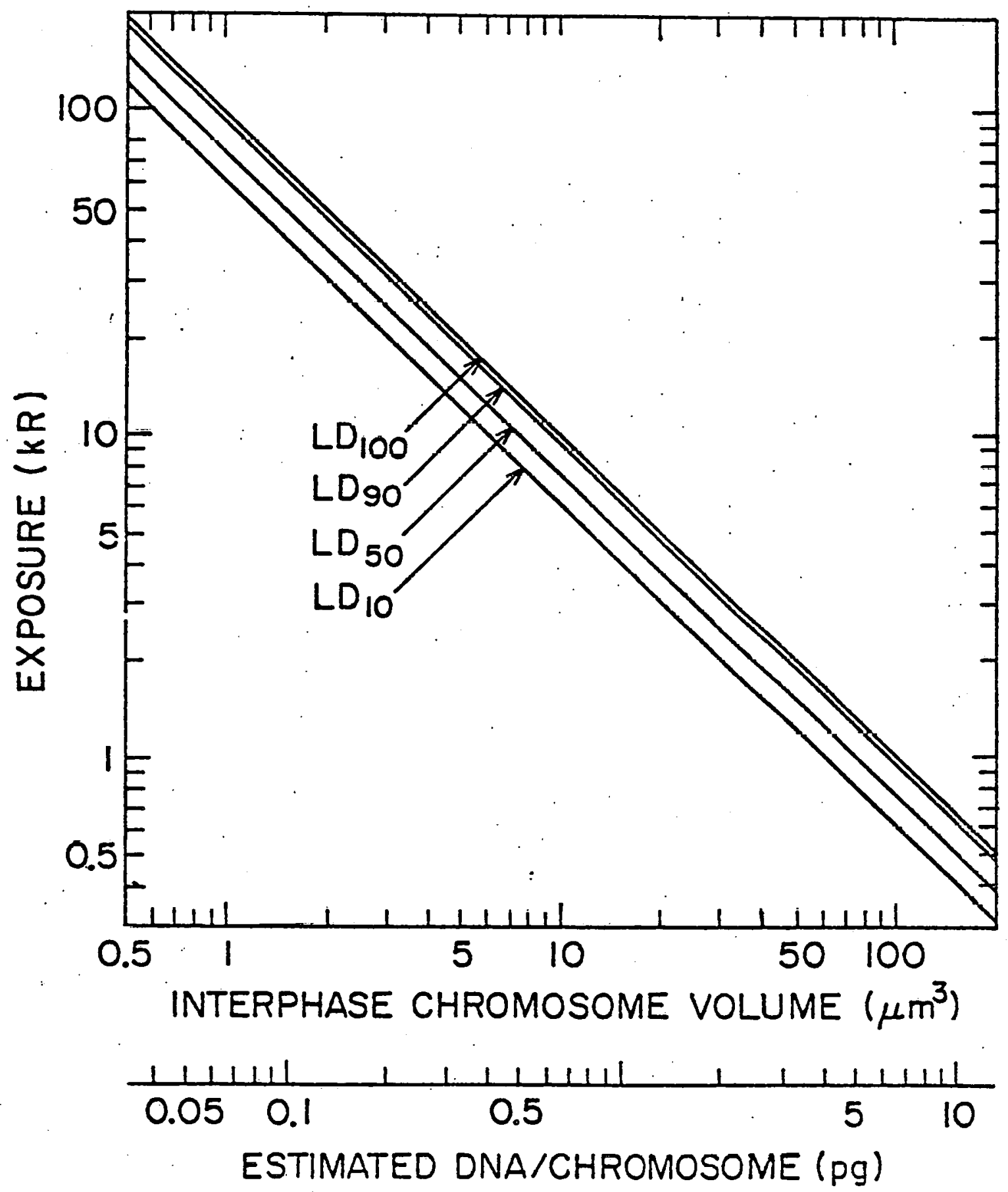

Fig. 6 


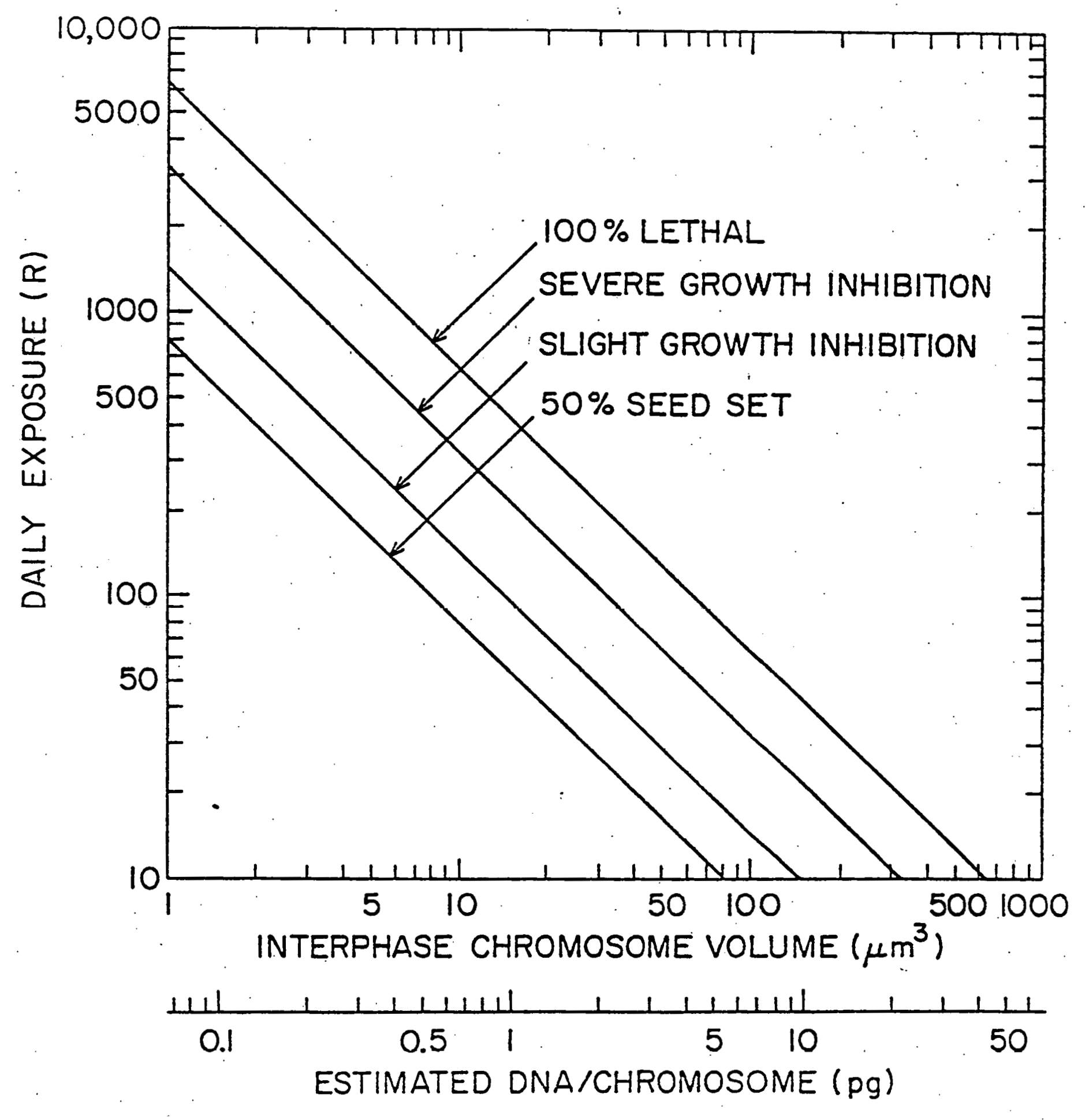




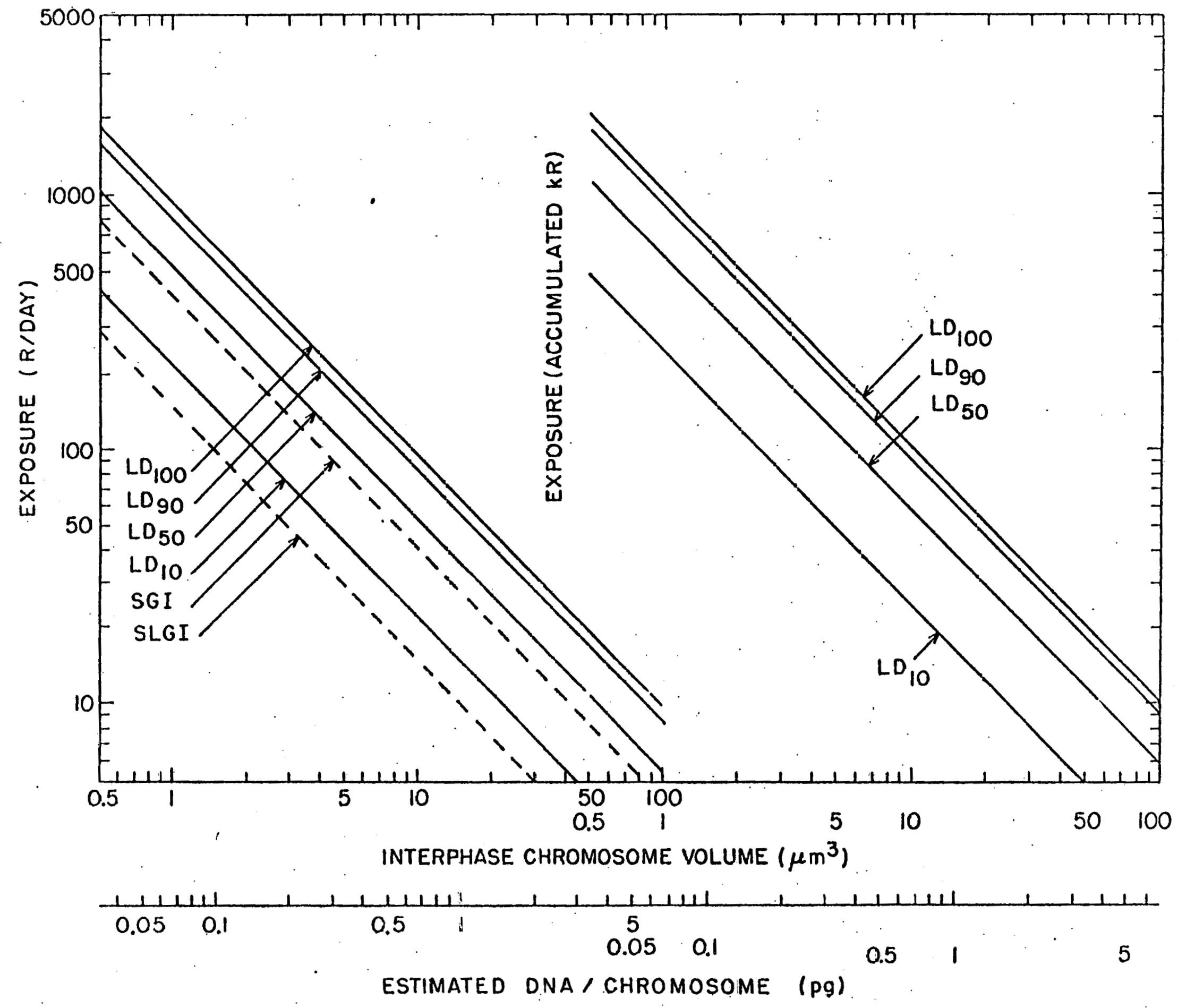




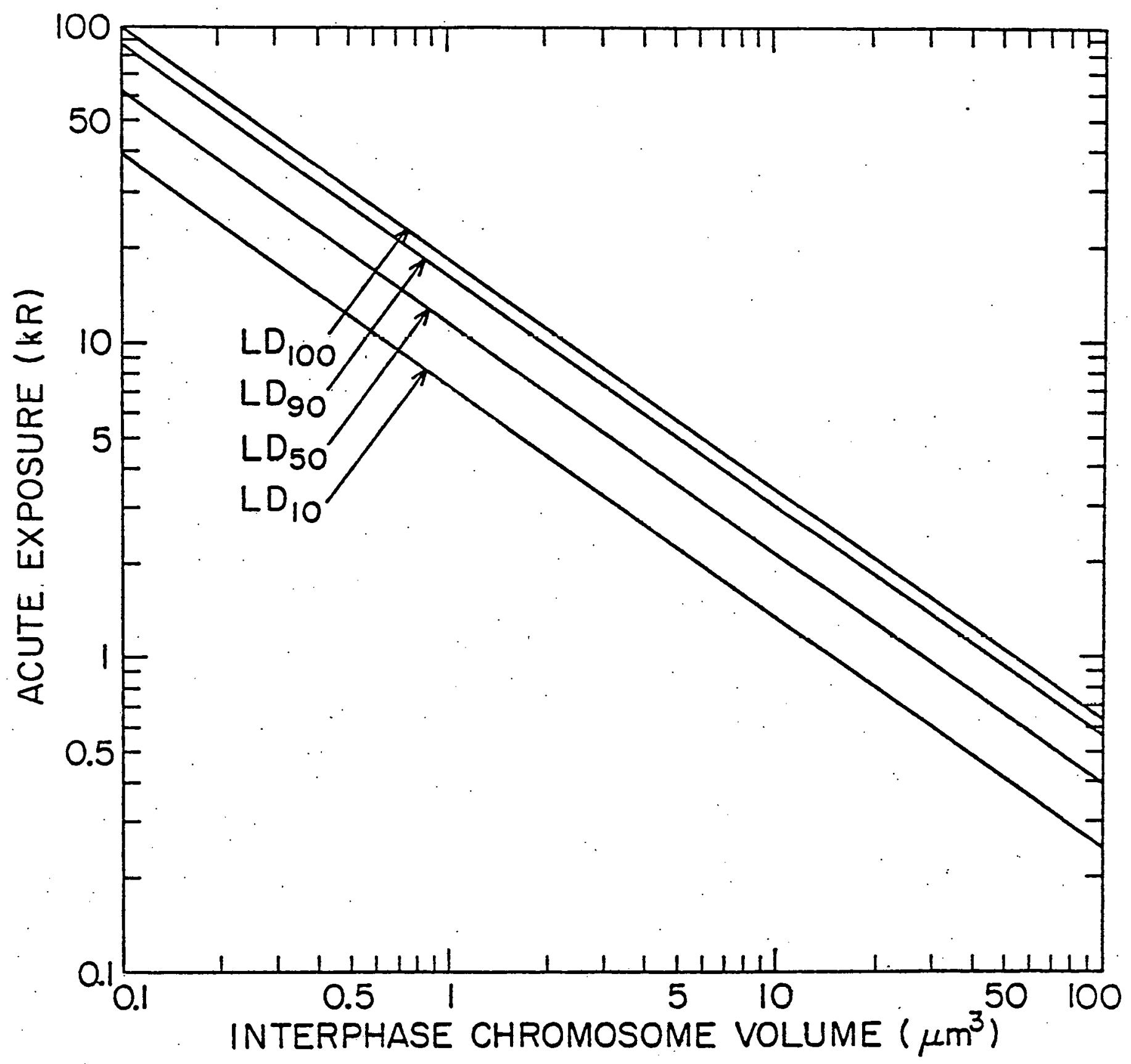

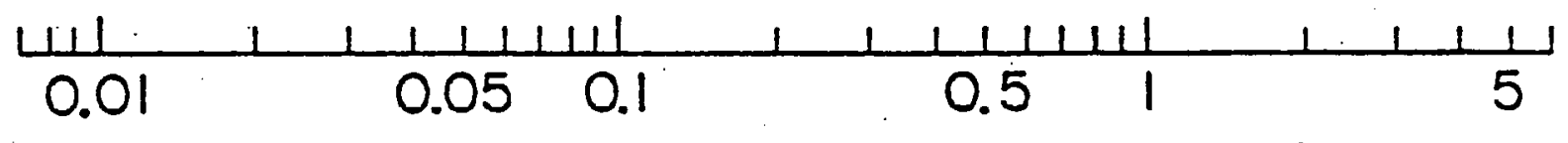

ESTIMATED DNA/CHROMOSOME (pg) 

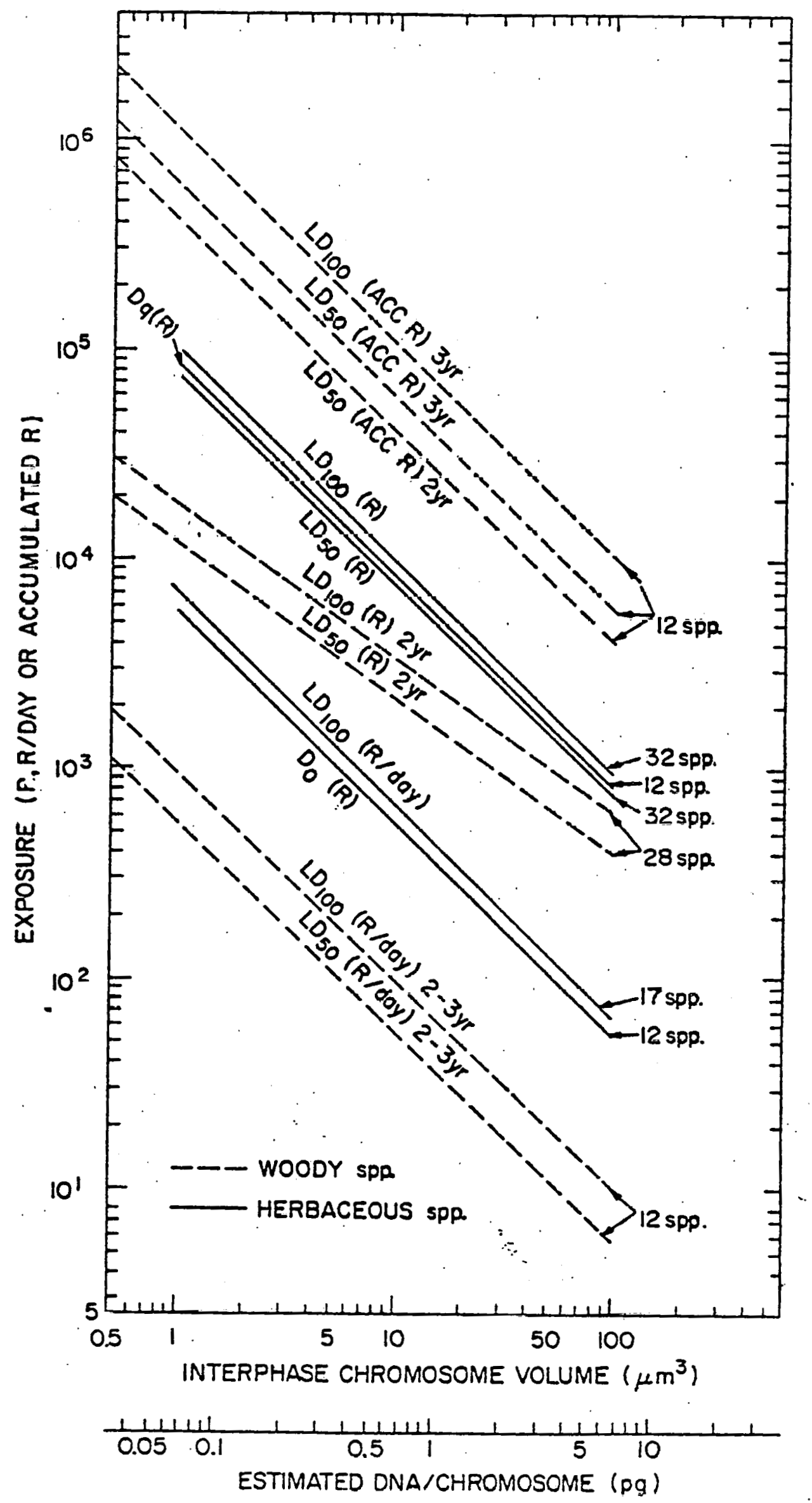

Fig. 10 
Table 1

Experimentally-decermined Radlosensitidites of 281 spectes of herbaceous plants

Whole-plant Irradiations b

\begin{tabular}{|c|c|c|c|c|c|c|c|c|c|c|c|c|c|c|}
\hline & \multirow[b]{3}{*}{ Specles } & \multirow[b]{3}{*}{$\begin{array}{l}\text { ICva } \\
\left(\mu_{m}^{3}\right)\end{array}$} & \multirow{2}{*}{\multicolumn{7}{|c|}{$\begin{array}{l}\text { Whole-plant 1rradiations }{ }^{b} \\
\text { Acute (kR) }\end{array}$}} & \multirow{2}{*}{\multicolumn{4}{|c|}{ Acute seej Irradiations (kR) }} & \multirow[b]{3}{*}{$\begin{array}{l}\text { Reference } \\
\text { (see key) }\end{array}$} \\
\hline & & & & \multicolumn{3}{|c|}{ Acute (kR) } & \multicolumn{3}{|c|}{ Chronle (R/day) } & & & & & \\
\hline & & & $2 D_{10}$ & $\mathrm{LD}_{50}$ & L. $\mathbf{9}_{90}$ & ${ }^{L} \cdot D_{100}$ & $\begin{array}{l}\text { Severe } \\
\text { ef fectc }\end{array}$ & $\begin{array}{l}50 \% \\
\text { soed } \\
\text { set }\end{array}$ & Lethal & $\begin{array}{c}50 x \\
\text { germination }\end{array}$ & $\begin{array}{l}50 \% \\
\text { seedling } \\
\text { dry wt. }\end{array}$ & $\begin{array}{c}50 \% \\
\text { seedling } \\
\text { survival }\end{array}$ & $\begin{array}{c}50 \% \\
\text { seedling } \\
\text { helght }\end{array}$ & \\
\hline 1 & Aethloncma saxat1118 & & & & & & & & & 375 & & 75 & & 1 \\
\hline $\begin{array}{l}2 \\
3\end{array}$ & All fum cepa & $\begin{array}{l}56.3 \\
39.3\end{array}$ & & & & & $401-800$ & & & & 13.0 & & & 2,3 \\
\hline 4 & A. cepa cv. Yanagucli1-kohdaka & ca38.2 & & & & & & 18 & & & & & & 4 \\
\hline 5 & $\frac{\text { A. eepa }}{\text { Spantsh }}$ cv. Yellow sweet & 45.6 & 2.50 & 2.90 & 3.18 & 3.50 & & 10 & & & & & & $\begin{array}{l}5 \\
6\end{array}$ \\
\hline $\begin{array}{l}6 \\
7\end{array}$ & A. fIstulosun cv. Kujyo & 29.5 & & & & & & 23 & & & & & & 5 \\
\hline 8 & $\frac{\text { A. sativim }}{\text { Aloc brevifolio }}$ & $\begin{array}{l}33.3 \\
65.5\end{array}$ & $\begin{array}{l}0.93 \\
2.27\end{array}$ & 1.12 & 1.66 & & & & & & & & & 7 \\
\hline 9 & Alopceuris agrescls & & & & & & & & & & & & & 7 \\
\hline 10 & A. myosuroddes & & & & & & & & & & & 20.0 & & 8 \\
\hline 11 & Alcliaed rosea & 3.90 & & & & & $401-800$ & & & & & 20.0 & & 9 \\
\hline 12 & Alyssum argenteun & & & & & & & & & 200 & & & & $\mathbf{3}$ \\
\hline 13 & A. saxatile & & & & & . & & & & 250 & & 60 & & 1 \\
\hline 14 & Allanas comosus & & 5.51 & 8.97 & 18.44 & & & & & 250 & & 65 & & 1 \\
\hline 15 & Anacyclus offercinarum & 11.0 & & & & 3.50 & & & & & & & & 7 \\
\hline 16 & Anechum graveolens & 6.0 & & & & & 750 & & 2000 & & & & & 4 \\
\hline 17 & Anfsantha sterilis & & & & & & & & & & & & & 4 \\
\hline 18 & Anchemis arvensis & & & & & & & & & & & 5.0 & & 8 \\
\hline 19 & Anterrhinum majus & 3.0 & & & & & 475 & & & & & 20.0 & & 8 \\
\hline 20 & Aphanosteplins skerrobas ls & 11.2 & & & & 8.00 & & & 1250 & & & & & 4 \\
\hline 21 & $\begin{array}{l}\text { Aplum graveolens var. } \\
\text { dulce cv. Corneli } 619\end{array}$ & 7.2 & & & & & & 50 & & & & & & $\begin{array}{l}4 \\
5\end{array}$ \\
\hline 22 & Arabls alpina & & & & & & & & & 200 & & 85 & & 1 \\
\hline 23 & Acabidops is tlanliana & 2.9 & & 30.30 & & 100.00 & 4000 & & & $>400$ & & 240 & & $1,4,10,11$ \\
\hline $\begin{array}{l}24 \\
25\end{array}$ & $\frac{\text { Arachis hypogaea }}{\text { Acriplex patula }}$ & 6.2 & & & & & & & & & 29.3 & 10,70 & & $2,12,13$ \\
\hline 26 & Avena fatua & & & & & & & & & & & 10.0 & & 9 \\
\hline 27 & $\bar{A} \cdot$ ludovictana & & & & & & & & & & & 18.0 & & 9 \\
\hline 28 & A. sativa & 19.7 & 3.24 & 4.10 & 4.96 & & & . & & & & 18.0 & & 9 \\
\hline 29 & Aubrleta del toidea & & & & & & & & & & & $17-27$ & $15-20$ & $12,14,15$ \\
\hline 30 & Barbarea praccox & & & & & & & & & $\begin{array}{l}150 \\
400\end{array}$ & & 45 & & 1 \\
\hline 31 & Beta vulgarls var. clela & 6.2 & & & & & & 130 & & 400 & & 60 & & 1 \\
\hline 32 & Biscutelia lelocarpa & & & & & & & & & & & & & 5 \\
\hline 33 & Brassica barrelleri & & & & & & & & & $\begin{array}{r}>400 \\
300\end{array}$ & & 100 & & 1 \\
\hline 34 & $\bar{B}$ juncea & 3.0 & & & & & & $\cdots$ & & $\begin{array}{r}300 \\
1300\end{array}$ & & 70 & & 1 \\
\hline 35 & B. napobrassica & 4.3 & & & & & & & & 1300 & & 240 & & 1 \\
\hline 36 & B. napus & 3.3 & & & & & & & & & & & $>100$ & 15 \\
\hline 37 & B. nikra & 4.3 & & & & & & & & $\begin{array}{l}350 \\
220\end{array}$ & 142.2 & $\begin{array}{c}130 \\
90,115.5\end{array}$ & $25-35$ & $\begin{array}{l}1,2,15 \\
1,9\end{array}$ \\
\hline
\end{tabular}


Table 1 (cont.)

Whole-plant Irradtationsb

\begin{tabular}{|c|c|c|c|c|c|c|c|c|c|c|c|c|c|c|}
\hline & \multirow[b]{3}{*}{ spectes } & \multirow[b]{3}{*}{$\begin{aligned} \text { ICVa } \\
\left.(\mu n)^{3}\right)\end{aligned}$} & \multicolumn{7}{|c|}{ 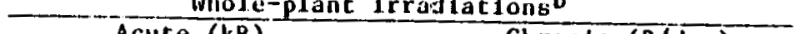 } & \multirow{2}{*}{\multicolumn{4}{|c|}{$\frac{\text { Acute Eeed 1rradiaclions (kR) d }}{50 \%}$}} & \multirow[b]{3}{*}{$\begin{array}{l}\text { Reference } \\
\text { (see key) }\end{array}$} \\
\hline & & & \multicolumn{4}{|c|}{ Acute (kR) } & \multicolumn{3}{|c|}{ Chron1c (R/day) } & & & & & \\
\hline & & & $\mathbf{L D}_{10}$ & $\mathrm{LD}_{50}$ & $L D_{90}$ & ${ }^{L D} D_{100}$ & $\begin{array}{l}\text { Severe } \\
\text { effectc }\end{array}$ & $\begin{array}{l}50 \% \\
\text { seed } \\
\text { set }\end{array}$ & Lethal & $\begin{array}{l}50 x \\
\text { germlnation }\end{array}$ & $\begin{array}{l}50 \% \\
\text { acedling } \\
\text { dry wt. }\end{array}$ & $\begin{array}{c}50 \% \\
\text { seedling } \\
\text { survival }\end{array}$ & $\begin{array}{c}50 \% \\
\text { seedling } \\
\text { helght }\end{array}$ & \\
\hline $\begin{array}{l}38 \\
39\end{array}$ & & 3.7 & & & & & & & & 250 & & 65 & & 1 \\
\hline $\begin{array}{l}39 \\
40\end{array}$ & $\begin{array}{l}\text { B. oleracea var. Capitata } \\
\text { B. oleracea var. Capltaca }\end{array}$ & 6.0 & 13.40 & 15.10 & 18.10 & 21.00 & & & & & & & & 6 \\
\hline & cv. Nozak I-nats suakl & 5.8 & & & & & & 50 & & & & & & 5 \\
\hline 41 & B. pekInensis cv. Kenshin & 4.3 & & & & & & 60 & & & - & . & & 5 \\
\hline 42 & $\frac{B}{n}=$ rapa & 3.0 & & & & & & & & $1 \cdot 10$ & & 60 & & $\begin{array}{l}3 \\
1\end{array}$ \\
\hline 43 & Brodlaea bridgesil & 21.5 & & & & & 160 & & & & & & & $\frac{1}{4}$ \\
\hline 44 & Bromus sterilis & & & & & & & & & & & 10 & & 9 \\
\hline 45 & $\frac{\text { Bunfas erucago }}{\text { B. orientalis }}$ & & & . & & & & & & 300 & & 85 & & $\mathbf{I}$ \\
\hline $\begin{array}{l}46 \\
47\end{array}$ & B. orlencalis & & & & & & & & & 300 & & 60 & & 1 \\
\hline 48 & Ca janus ca jan & & & & & & & & & & & 15 & & 12 \\
\hline 49 & Camelina alyssum & 1.8 & & & & & & & & & & 70 & & 13 \\
\hline 50 & Canna generails & & & & & & $: 01-400$ & & & $>400$ & & 150 & & 1 \\
\hline 51 & Canabis sativa & & & & & & & & & & & & & 3 \\
\hline 52 & Capse1 la bursa-pascoris & 2.1 & 48.00 & 58.00 & 63.50 & 10.00 & . & & & & & & ca. 7 & 15 \\
\hline 53 & Capsicun frutescens & 6.5 & & & & & $201-400$ & & & 400 & & $170,87.6$ & & $1,6,9$ \\
\hline 54 & c. f rutescens & 6.5 & & & & & & 110 & & & & 24 & & 3,12 \\
\hline 55 & & & & & & & & & & & & & & 5 \\
\hline 56 & Cardarla deaba & 3.2 & & & & & & & & 350 & & 130 & & 1 \\
\hline 57 & Celosta cristata & & & & & 1 & $4 i) 1-800$ & & & 400 & & 80 & & 1 \\
\hline 58 & Cerastum vulgatun & & & & & 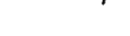 & & & & - & & & & 3 \\
\hline 59 & Cheiranthus chetri & & & & & & & & & & & 80 & & 8 \\
\hline 60) & Chenopod lum album & 4.4 & & & & & $401-800$ & & & $>400$ & & 225 & & 1 \\
\hline 61 & Chlorophytum elatiun & 15.1 & . & & & 2.00 & & & 450 & & & 15.1 & & 3,9 \\
\hline 62 & Chrysanchem arcticum & 10.1 & & & & 15.00 & $801-1600$ & & & & & & & 4 \\
\hline 63 & c. corymbossun & 15.0 & & & & 4.50 & & & & & & & & 3,4 \\
\hline 64 & c. Jrcuttanum & 12.8 & & & & & $401-800$ & & & & . & & & 4 \\
\hline 65 & c. lacustre & 11.3 & 6.49 & 7.80 & & 9.00 & $801-1600$ & & & & & & & 3 \\
\hline 66 & c. Itpponteim & 17.7 & 2.42 & 3.02 & 3.43 & 4.00 & $209-400$ & & & & & & 21,1 & $3,4,7,16$ \\
\hline 67 & C. segetuin & & & & & & & & & & & & & 3,6 \\
\hline 68 & c. yezoense & 13.6 & 8.45 & 9.15 & 9.95 & 11.00 & $801-1600$ & & & & & 26.2 & & 9 \\
\hline 69 & CI trullus vulgards & 4.3 & & & & & & & & & & 60 & & 3,6 \\
\hline 70 & $\frac{\text { C. vulgaris cv. }}{\text { Koligyoku-midori }}$ & 5.3 & & & & & & 170 & & & & 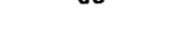 & & $\begin{array}{l}12 \\
5\end{array}$ \\
\hline 71 & Cochlearla offelnalls & & & & & & & & & & & & & \\
\hline 72 & Coleus bluuet & 4.5 & & & & & $201-400$ & & & 230 & & 70 & & 1 \\
\hline 73 & Couringia orjencalds & & & & & & & & & & & & & 3 \\
\hline 74 & Coronopus squanatus & & & & & & & & & $\begin{array}{l}120 \\
400\end{array}$ & & 80 & 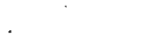 & 1 \\
\hline 75 & Cosinos biptnnatus & & & & & & $101-200$ & & & & & 110 & . & 1 \\
\hline 76 & Crambe hispantea & & & & & & & & & 300 & & $70-100$ & & 3,13 \\
\hline 77 & Crepiscapiluaris & 10.6 & & & & 3.75 & & & 700 & & & 120 & & 1 \\
\hline 78 & $\begin{array}{l}\text { Cucuinis melo var. } \\
\text { makuwa cv. Ohgon-nashi }\end{array}$ & 6.3 & & & & & & 270 & & & & & & $\begin{array}{l}4 \\
5\end{array}$ \\
\hline 79 & c. saci vus & 8.4 & & & & & . & & & & & & & \\
\hline 80 & $\begin{array}{l}\bar{c} \text { c. sattuns cu. } \\
\text { Chyojlesu-ochial }\end{array}$ & 6.5 & & & & & & 240 & & & 86.1 & $<20$ & & $\begin{array}{l}2,12 \\
5\end{array}$ \\
\hline 81 & $\frac{\text { Cucurblta maxima }}{\text { Tokyo-kabocitua }}$ cv. & 3.7 & & & & & & 280 & & & & & & \\
\hline & & & & & & & & & & & & & & 5 \\
\hline
\end{tabular}


table I (cont.)

Whole-plant Irradiations b

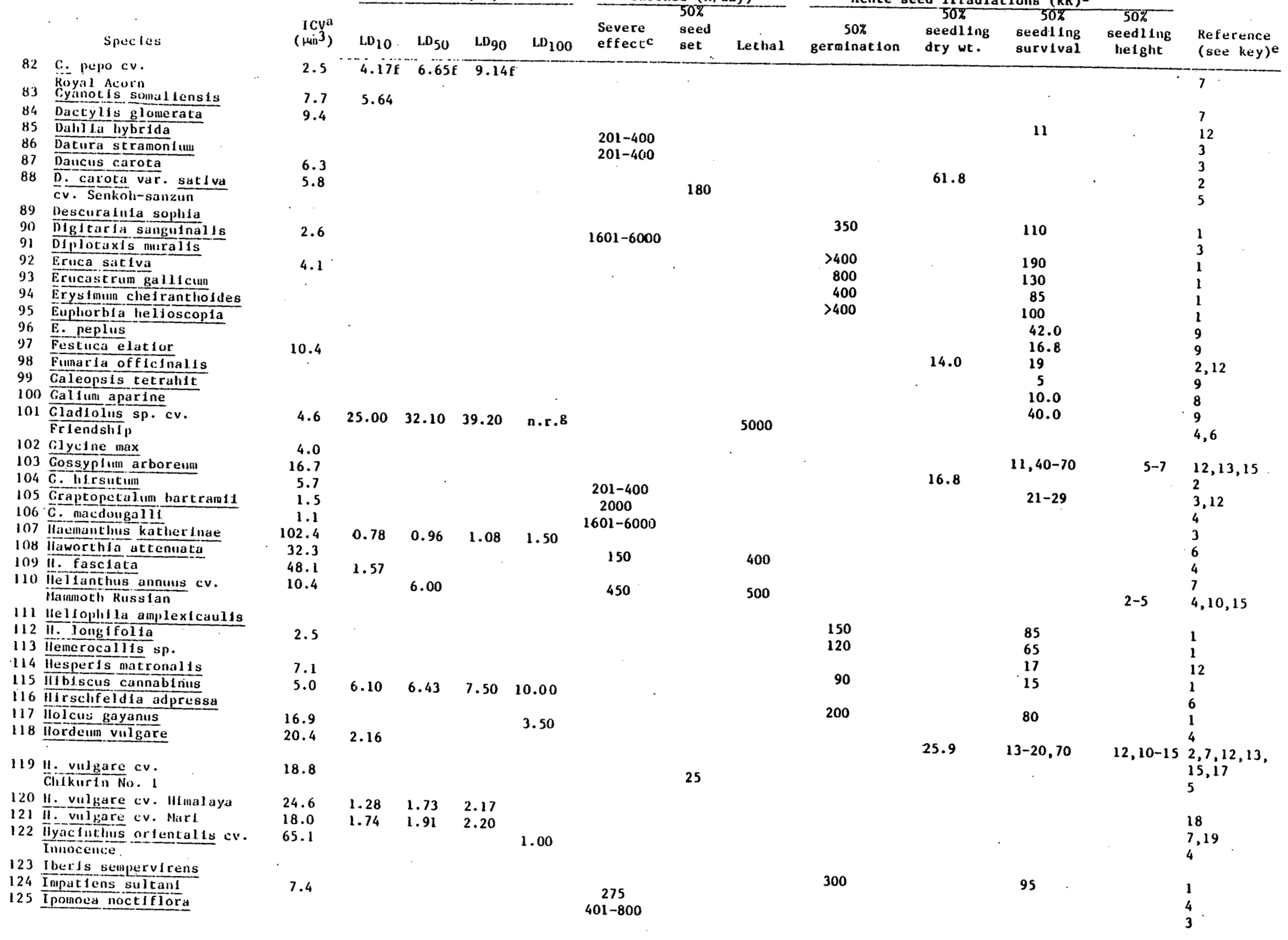


l'able 1 (cont.)

Whole-plant trradiactons

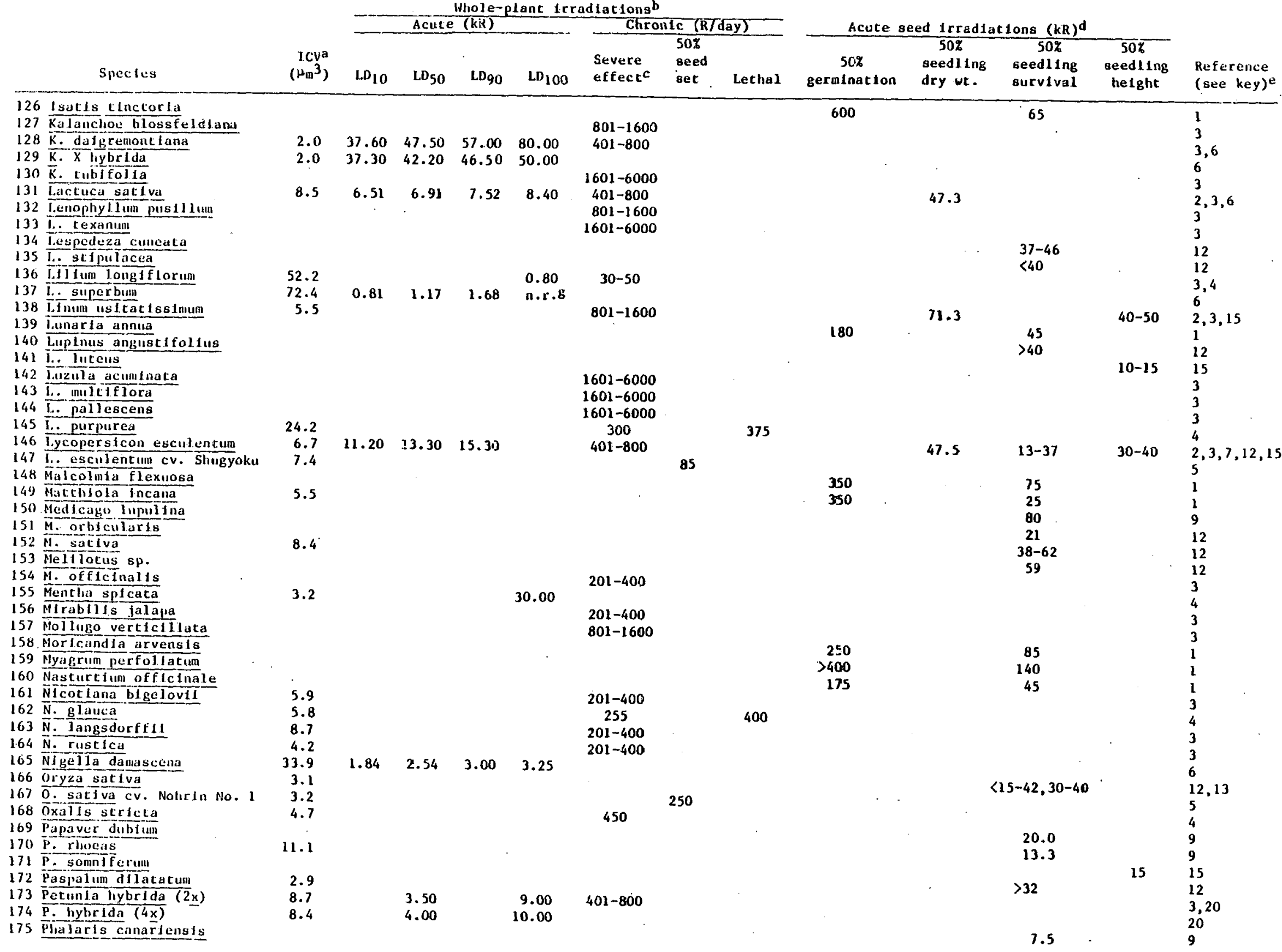


Table 1 (cont.)

Whole-plant Irradiations $b$

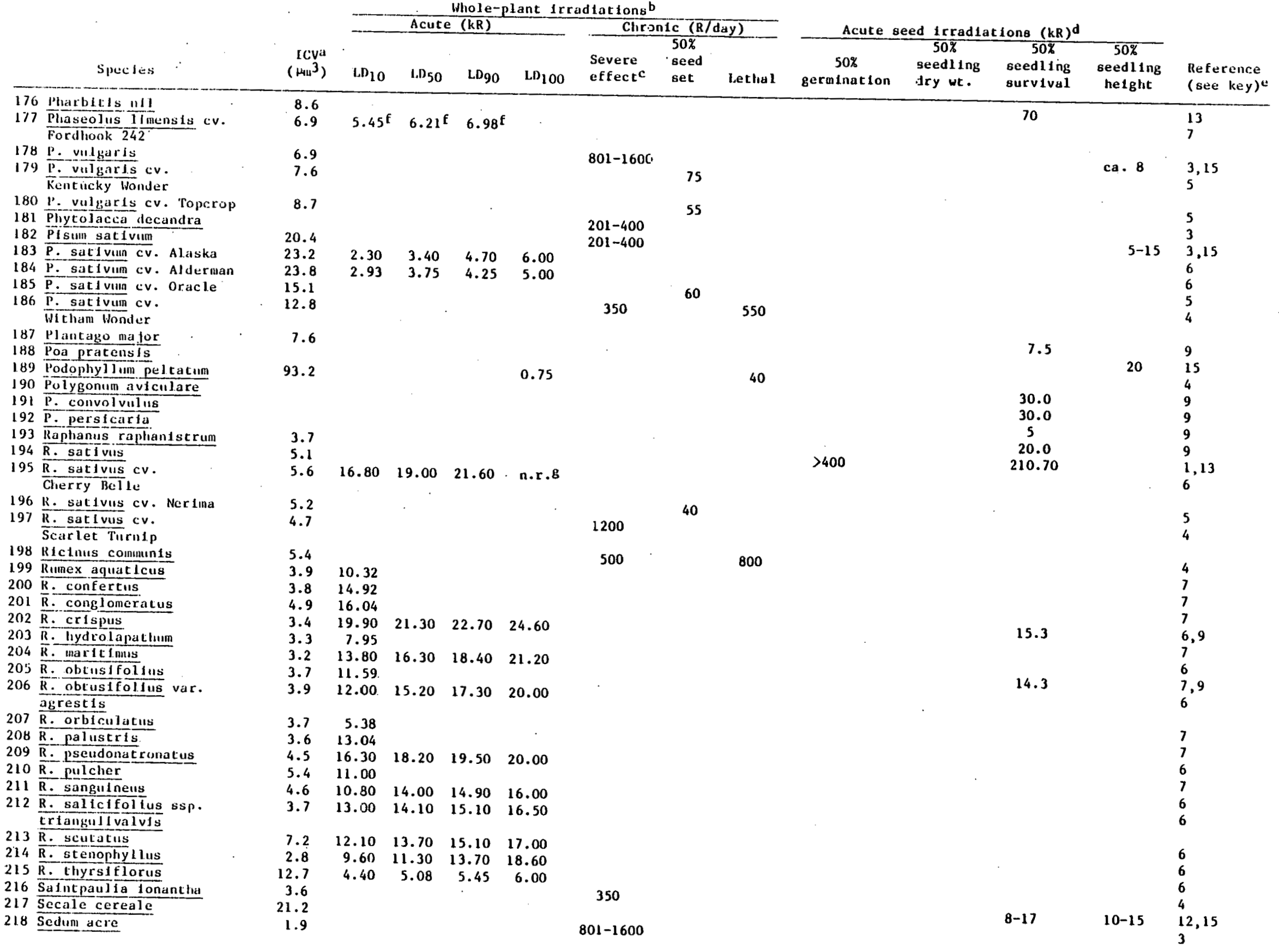


Table 1 (cont.)

Whole-plant 1rradlattons b

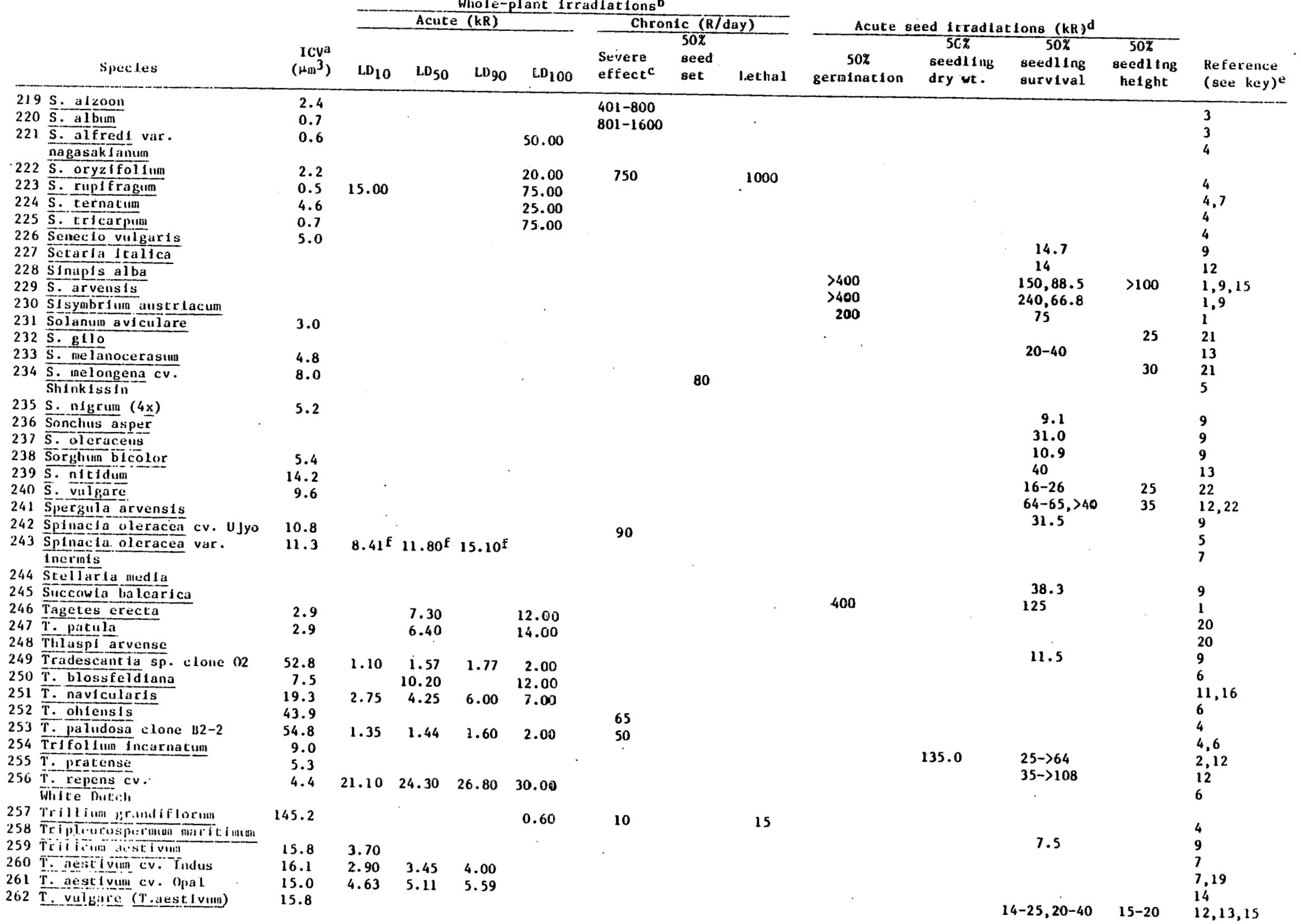




\begin{tabular}{|c|c|c|c|c|c|c|c|c|c|c|c|c|c|c|}
\hline & \multirow{3}{*}{ 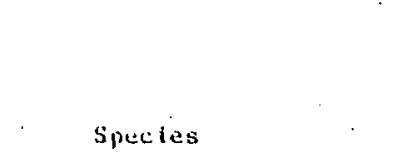 } & \multirow[b]{3}{*}{$\begin{array}{l}\text { ICVa } \\
\left.\left(\mathrm{H}_{11}\right)^{3}\right)\end{array}$} & \multicolumn{7}{|c|}{ Whole-plant Irradracionso } & \multirow{2}{*}{\multicolumn{4}{|c|}{ Acule seed irradiations (kR)d }} & \multirow{3}{*}{$\begin{array}{l}\text { Reference } \\
\text { (see key) }\end{array}$} \\
\hline & & & \multicolumn{4}{|c|}{ Acute (kR) } & \multicolumn{3}{|c|}{ ChEon1c (R/day) } & & & & & \\
\hline & & & $\mathrm{LD}_{10}$ & L. $D_{50}$ & LD90 & $1 . D_{100}$ & $\begin{array}{l}\text { Severe } \\
\text { effecte }\end{array}$ & $\begin{array}{l}50 \% \\
\text { seed } \\
\text { set }\end{array}$ & Lethal & $\begin{array}{c}50 \% \\
\text { germination }\end{array}$ & $\begin{array}{l}50 \% \\
\text { seedling } \\
\text { dry wt. }\end{array}$ & $\begin{array}{c}50 \% \\
\text { seedling } \\
\text { gurvival }\end{array}$ & $\begin{array}{c}50 \% \\
\text { seedling } \\
\text { helght }\end{array}$ & \\
\hline 263 & Tropacolum ma jus & 5.9 & 9.00 & 11.50 & 13.70 & 15.00 & & & & & & & & 6 \\
\hline 264 & Tulbaghia violacea & 37.5 & & & & & 45 & & 120 & & & & & 4 \\
\hline 265 & Urtica "urens & & & & & · & & & & & & 37.0 & & 9 \\
\hline 266 & Veronica persica & & & & & & & & & & & 129.5 & & 9 \\
\hline 267 & v. poilta & & & & & & & & & & & 104.7 & & 9 \\
\hline 268 & vicia augustif folla & 12.7 & & & & & $201-400$ & & & & & & & 3 \\
\hline 269 & v. Faba & 48.8 & 0.64 & 0.98 & 1.34 & 1.50 & 135 & & 205 & & & & & 4.6 \\
\hline 270 & V. temulfolla & & & & & & $201-400$ & & & & & & $\therefore$ & 3 \\
\hline 271 & v. viliosa. & 11.6 & & & & & & & & & & 17 & & 12 \\
\hline 272 & vigna sinensts & 6.5 & & & & . & . & & & & & $11,40-70$ & & 12,13 \\
\hline 273 & Vtola arvensis & & & . & & & & & & & & 40.0 & & 9 \\
\hline 274 & Xanthlum sp. & & & & & & $401-800$ & & & & & & & 3 \\
\hline 275 & Yucca brevifolla & & & & & & & & & & & 53 & & 23 \\
\hline 276 & Zea mays & 14.5 & & & & & & & & & & $>15,40$ & & 12,13 \\
\hline 277 & 7. mays cv. Colden Bantam & 15.0 & 4.85 & 5.23 & 5.95 & 7.00 & 500 & & 670 & & & & & 4,6 \\
\hline 278 & Z. matys hybrid & 14.1 & $4.06 \mathrm{~F}$ & 5.10 & $5.92 f$ & & & & & & & & & 7,24 \\
\hline 279 & 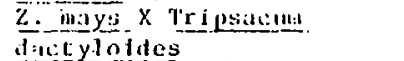 & & & & & & & & & & & $<10$ & & 12 \\
\hline 280 & 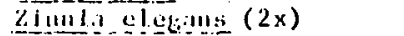 & 5.1 & & 2.20 & & 3.00 & & & & & & & & 20 \\
\hline 281 & $z$ elepins $(4 \bar{x})$ & 3.2 & & 7.20 & & 15.00 & & & & & & & & 20 \\
\hline
\end{tabular}

a If ICV differs fron that given in Table 5, the value given here was determined from experimental control plants, or was taken from the same source as sensicivity dita.

Whitil different values have been published by the same author(s), the most recently-published figures have been used here.

cllsulaly explessed as severe growth inhibition.

Data on additfonal end polnts and percentage of effect are tabulated by Osborne Constantin (1966) and Fuj11 Matsumura (1958).

'References:

1: Gomez-Campo \& Delgado (1964)

2. Osborne \& Lunden (1964)

9. Bowen (1962)

10. Donin1, Sparrow, Schairer \& Sparrow (1967)

17. Caldecote (1961)

10. Donin1, Sparrow, Schairer Sparrow

4. Sparrow, Sparrow, Thompson \& Schairer (1965) 12. Osborne \& Lunden (1961)

5. Yamakawa \& Sparrow (1965)

13. Fuj11 \& Matsumura (1958)

6. Sparrow \& schwenumer (1974)

13. Fujll \& Matsumura (1958)

18. Bottino \& Bores (1973)

7. Sparrow, Scliwenmer \& Botelno (1971)

14. Bottino \& Sparrow (197laj

19. Bottino os Sparrow (1971b)

$\begin{array}{ll}\text { 15. Gustaffon \& von Wettstein (1958) } & \text { 23. Johnstone \& Klepinger (1967) } \\ \text { 16. Baetcke, Spartow, Nauman \& Schwemer (1967) 24. Sparrow, Floyd \& Bottino (1970) }\end{array}$

20. Miller (1970)

8. Bowent \& Snith (1959)

Eensitivity from FIS exposure (fallout decay simulation). Included only when other data not avallable.

Blechial dose not reached. 
Table 2

Experimentally-determined radiosensitivites of 62 specles of woody plants

\begin{tabular}{|c|c|c|c|c|c|c|c|c|c|c|c|c|c|c|c|c|c|}
\hline \multirow{3}{*}{\multicolumn{2}{|c|}{ Spectes }} & \multirow{3}{*}{$\begin{array}{l}1 \mathrm{cova} \\
\left(\mathrm{Hin}_{13}{ }^{3}\right)\end{array}$} & \multicolumn{11}{|c|}{ Whole-plant Irradiationsb } & \multirow{2}{*}{\multicolumn{3}{|c|}{ Seed Irraclations (KR) }} & \multirow[b]{3}{*}{$\begin{array}{l}\text { Reference } \\
\text { (see key) }\end{array}$} \\
\hline & & & \multicolumn{6}{|c|}{ Acute (kR) } & \multicolumn{5}{|c|}{ Chrantc (R/day) } & & $5 C \%$ & & \\
\hline & & & $L D_{10}$ & $\mathrm{LI}_{50}$ & $L D_{90}$ & $\mathrm{LV}_{100}$ & $\begin{array}{l}\text { Severe } \\
\text { effectc }\end{array}$ & $\begin{array}{l}\text { Sitght } \\
\text { effectc }\end{array}$ & $\mathrm{LD}_{10}$ & $\mathrm{LD}_{50}$ & LOgo & $\mathrm{LD}_{100}$ & $\begin{array}{l}\text { Severe } \\
\text { effectio }\end{array}$ & $\begin{array}{l}\text { germi- } \\
\text { aation }\end{array}$ & $\begin{array}{l}\text { sur- } \\
\text { vival }\end{array}$ & $\begin{array}{l}\text { dry } \\
\text { weightd }\end{array}$ & \\
\hline $\begin{array}{l}1 \\
2\end{array}$ & $\frac{\text { Abies bal sanea }}{\text { Acer rubrun }}$ & 46.4 & 0.43 & 0.89 & 1.36 & 1.50 & 0.60 & & & & & $18.0^{\circ}$ & & & & & 1,2 \\
\hline $\begin{array}{l}2 \\
3\end{array}$ & $\frac{\text { Acer rubrua }}{\text { A. saccharum }}$ & 6.5 & 2.87 & 5.11 & 7.36 & 8.00 & 6.00 & 4.50 & 62.0 & 130 & 198 & 205 & $101-200$ & & & & $1,2,3,4$ \\
\hline 4 & A. $\frac{\text { saccharum }}{\text { A. }}$ & 4.8 & 3.41 & 4.72 & 6.03 & 8.00 & 6.00 & 3.00 & 10.5 & 77.9 & 145 & 185 & & & & & $1,2,3$ \\
\hline 5 & Betula lutea & 3.2 & 2.47 & 4.28 & 7.69 & 8.00 & 6.00 & 2.00 & 55.5 & 83.1 & 111 & :57 & $101-200$ & & & & \\
\hline 6 & $\frac{\text { Buddlefa }}{\text { alternifolia }}$ & 2.2 & 3.39 & 7.05 & 10.72 & $9.00^{e}$ & & . & & & & 251 & & & & & $1,2,3$ \\
\hline 7 & $\frac{\overline{\text { B. davidil }}}{\text { Carica papaya }}$ & 0.9 & 15.18 & 17.50 & 19.82 & 20.00 & & & & & & & & & & & 1 \\
\hline $\begin{array}{l}8 \\
9\end{array}$ & $\frac{\text { Carica papaya }}{\text { Clemat is virginiand }}$ & 16.0 & 1.31 & 1.89 & 2.47 & & & & & & & & & & 12 & & $\begin{array}{l}1 \\
5\end{array}$ \\
\hline 10 & $\frac{\text { Clemat is virbliniand }}{\text { Coffea arabica }}$ & 3.9 & & & 2.47 & 2.70 & & & & & & & & & & & i \\
\hline 11 & Cornus florta & 6.9 & & & & & & & & & & & & & $<10$ & & 5 \\
\hline 12 & Fraxinus americana & 4.7 & 5.68 & 7.74 & 9.81 & 10.00 & 9.00 & 3.50 & 58.7 & 132 & & & $51-100$ & & & & 4 \\
\hline 13 & GaylussacIa sp. & & & & & & & & & & $\begin{array}{r}205 \\
70\end{array}$ & 265 & & & & & $1,2,3$ \\
\hline 14 & Juniperus conterta & 22.7 & & 1.06 & 1.4 & & & & & & & & & & & & 6 \\
\hline $\begin{array}{l}16 \\
17\end{array}$ & $\frac{\text { Kalmia latlfol a }}{\text { Lardx larfeina }}$ & 46.3 & 0.43 & 0.71 & 0.98 & 1.10 & & & & & & & $201-400$ & & & & $\begin{array}{l}2 \\
4\end{array}$ \\
\hline 18 & L. leptojepis & 48.5 & 0.48 & 0.83 & 1.52 & $1.50^{\mathrm{b}}$ & 1.00 & 0.70 & 6.8 & & & & & 3.82 & 2.51 & 4.43 & $1,8,9$ \\
\hline 19 & $\frac{\text { Liriodendron }}{\text { Euldiffera }}$ & 6.4 & & & & & & & 6.8 & 14.1 & 21.4 & a1.5 & $201-400$ & & & & $1,2,3$ \\
\hline 20 & $\begin{array}{l}\text { Paeonia } \\
\text { suffrut cosa }\end{array}$ & 57.3 & 0.20 & 0.48 & 1.04 & $1.00^{\mathrm{f}}$ & & $\because$ & & & . & & & & & & 1 \\
\hline 21 & Plcea ables & 42.6 & 0.91 & 1.10 & 1.29 & 1.35 & & & & & & & & 2.22 & $1,1.38$ & 2.11 & $1,8,9,10$ \\
\hline $\begin{array}{l}22 \\
23\end{array}$ & $\frac{\text { P. glauca }}{\text { P. mariana }}$ & 45.3 & 0.49 & 0.78 & 1.07 & 1.13 & 0.90 & 0.30 & 9.8 & 13.0 & 16.2 & 17.3 & & 3.19 & 2.90 & 3.07 & $\begin{array}{l}1,0,9,10 \\
1,2,3,8,9\end{array}$ \\
\hline 24 & P. marlana & $\begin{array}{l}33.1 \\
40.7\end{array}$ & 0.96 & $\begin{array}{l}0.648 \\
1.19\end{array}$ & 1.42 & 1.50 & & . & & & & & & 4.06 & 3.34 & 5.58 & $8,9,11$ \\
\hline 25 & p. rubens & 36.9 & 0.77 & 1.03 & 1.29 & 1.50 & & & & & & & & & & $\cdot$ & 1 \\
\hline 26 & p. slcehensis & 35.4 & & & & & & & & & & & & & & & 1 \\
\hline 27 & pleris japontca & 4.1 & & & & & & . & & & . & & $401-800$ & 1.92 & 1.40 & & 12 \\
\hline 28 & Plous bankslana & 45.5 & & $0.66 \mathrm{~B}$ & & & & & & & & & $401-600$ & & & & 4 \\
\hline 29 & P. contorta & 45.6 & & 0.708 & & & & & & & & & & 11.40 & 9.05 & 11.67 & $8,9,11$ \\
\hline 30 & P. Elloth & 39.2 & & 0.63 & & 0.90 & & & & & & & & & 5.51 & 6.69 & $8,9,11$ \\
\hline 31 & P.palustrTs & & & 0.73 & & 1.10 & & & & & & & & & & & 7 \\
\hline 32 & P. ponderosa $x$ & 45.6 & 0.62 & 0.82 & 1.01 & 1.20 & & & & & & & & & & & $\begin{array}{l}7 \\
1\end{array}$ \\
\hline 33 & P.resinosa & 47.7 & 0.60 & 0.78 & 0.97 & $n \cdot r^{h}$ & & & 1.7 & 7.5 & 13.2 & 19.3 & & & & & \\
\hline 34 & P. rIg1da & 48.3 & & & & & & & & & 23 & 17.5 & & 4.80 & 3.83 & 8.72 & $1,3,8,9$ \\
\hline $\begin{array}{l}35 \\
36\end{array}$ & $\frac{\text { P. strobus }}{\text { P. sylvestris }}$ & $\begin{array}{l}66.7 \\
53.6\end{array}$ & 0.27 & 0.47 & 0.68 & 0.75 & 0.42 & 0.15 & 3.9 & 7.5 & 11.2 & 12.1 & & & & & $\begin{array}{l}2,6 \\
1,2,3\end{array}$ \\
\hline 37 & $\frac{\text { Podocarpus }}{\text { macrophylia }}$ & 13.1 & & 0.58 & & 1.84 & & & & & & & & 2.92 & $1,2.6 .9$ & 2.93 & $8,9,10$ \\
\hline 38 & $\frac{\text { Prunus } 1 \text { auracerasus }}{\text { cv. Schtpkaensis }}$ & 4.2 & 1.32 & 3.00 & 4.68 & 6.00 & & & 3.4 & 27.7 & 52.0 & 95 & & & & & 1,3 \\
\hline 39 & P. persica & 3.6 & & & & & & & & & & & $201-400$ & & & & 4 \\
\hline
\end{tabular}


Whole-plant irrajlactonsb

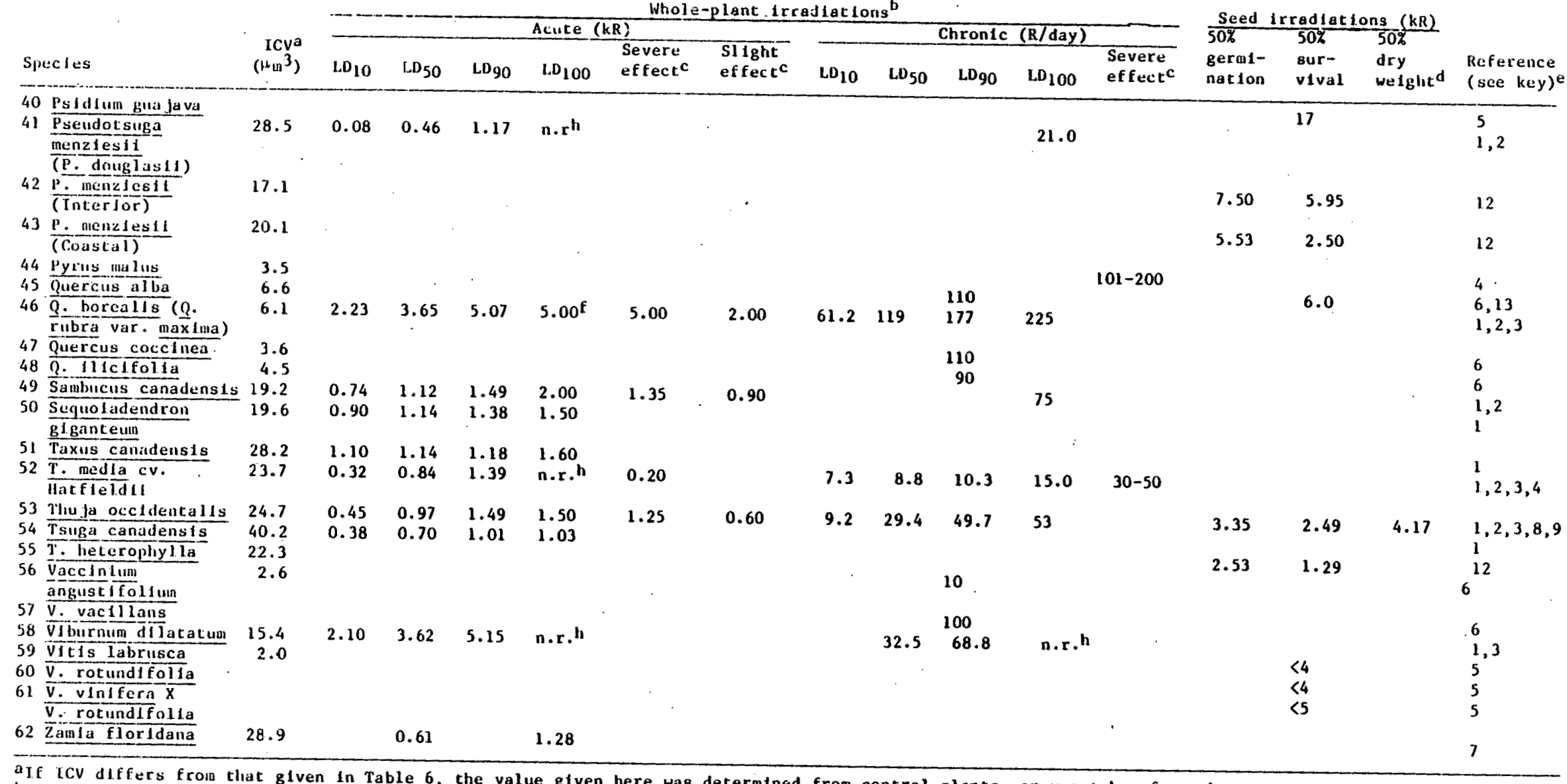

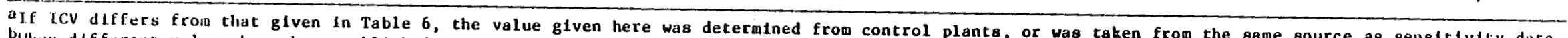
bulien diffecent valites have been published by the sume author(s) the most recent figures have been used here.
cCenerally expressed as growth inhtbition. cenerally expressed as growth inhtbition.

erefurences:

1. Sparrow, Rogers \& Scliwemuer (1968)

2. Sparrow, Sparrow. Thumpgon \& Schatrer (1965)

3. Sparrow, Schwernmer, Klag o Puglielli (1970a)

4. Sparrow S Cunckel (1956)

6. Hoodwell \& Sparrow (1963)

7. Capella \& Conger (1967)

8. Rudolph \& Mikache (1970)

10. Bowen (1962)

9. Miksche \& Rudolph (1958)

11. Rudolph (1971)

12. El Lakany 6 Szikla1 $(1970 a, b)$

13. Stairs (1963)

filin $L D_{100}$ is exceeded by L.D90, LD 100 is generally an observed value and LD 90 18 computer-estimated from survival curves.

gvery youling seedlings.

hlethal dose not reached. 
Table 3

Chromosome number, nuclear volune, ICV and sensitivity $\left(D_{0}\right)$

of one-celled gametophytes of 29 species of ferris.

\begin{tabular}{|c|c|c|c|c|c|}
\hline & Species & $\begin{array}{l}\text { Chromosome } \\
\text { Number } \\
\text { (ln })\end{array}$ & $\begin{array}{c}\text { Nuclear } \\
\text { volume }{ }^{a} \\
\left(\mu \mathrm{m}^{3}\right)\end{array}$ & $\begin{array}{c}\text { ICV } \\
\left(\mu m^{3}\right)\end{array}$ & $D_{0}(k r a d)^{b}$ \\
\hline 1 & Adiantum pedatum $\mathrm{L}$. & c.29c & 319 & 11.0 & 3.29 \\
\hline 2 & A. tenerum Sw. & 30 & 278 & 9.3 & 2.14 \\
\hline 3 & Anglopterls hypoleuca de Vriese & c. 80 & 175 & 2.2 & \\
\hline 4 & Asplenfum nidus L. & -36 & 293 & 8.1 & \\
\hline 5 & A. ruta-muraria L. & c. 72 & 300 & 4.2 & \\
\hline 6 & Blechnum Indicum Burm. & -36 & 502 & 13.9 & 2.16 \\
\hline & B. patersonif (R. Br.) Mett. & 60 & 385 & 6.4 & \\
\hline & B. splcant (L.) J. Sm. & 34 & 366 & 10.8 & 1.84 \\
\hline 9 & Cheilanthes hirta-el11siana & $c .116$ & 820 & 7.1 & 3.81 \\
\hline 10 & Cryptogramma crispa (L.) R. Br. & $=30$ & 372 & 12.4 & 2.58 \\
\hline 11 & Cyclosorus unitas (L.) Ching & $36^{c}$ & 188 & 5.2 & \\
\hline 12 & Cystopteris fragilis (L.) Bernh. & $84^{c}$ & 598 & 7.1 & \\
\hline 13 & Dryopteris filix-mas (L.) Schotr & $82^{c}$ & 652 & 8.0 & 2.80 \\
\hline 14 & Lygodium japonicum (Thunb.) Sw. & 58 & 558 & 9.6 & 1.61 \\
\hline 15 & Onoclea sensibilis $\mathrm{L}$ & 37 & 717 & 19.4 & 1.16 \\
\hline 16 & Osmunda cInnamomea $\mathrm{L}$. & $22^{\mathrm{C}}$ & 1887 & 85.8 & \\
\hline 17 & 0. regalis $\mathrm{L}$ & 22 & 462 & 21.0 & 0.63 \\
\hline 18 & Phymatodes nigrescens (B1.) J. Sm. & $36^{c}$ & 365 & 10.1 & \\
\hline 19 & Pityrogramma triangularis (Kaulf.) Maxon & $\underline{c .} .60$ & 410 & 6.8 & \\
\hline 20 & Polypodium australe Fee & $\bar{c} .90$ & 1119 & 12.4 & 1.24 \\
\hline & & & 1403 & 15.6 & 1.59 \\
\hline 21 & P. inter jectum Shivas \& Manton & 111 & 589 & 5.3 & \\
\hline 22 & P. vulgare L. & c. 74 & 674 & 9.1 & 2.23 \\
\hline 23 & Polystichum aculeatum (L.) Roth & -82 & 380 & 4.6 & 3.14 \\
\hline 24 & Pteridium aquilinum (L.) Kuhn & $52^{\mathrm{C}}$ & 435 & 8.6 & \\
\hline 25 & Pteris longifolia L. & 58 & 922 & 15.9 & \\
\hline 26 & P. quadriaurita Retz. & c. 87 & 345 & 4.0 & \\
\hline 27 & Rumohra adiantiformes (G. Forst.) Ching & $-41 c$ & 368 & 9.0 & \\
\hline 28 & Woodwardia orientalis Sw. & 34 & 510 & 15.0 & \\
\hline 29 & W. radicans (L.) Sm. & 34 & 459 & 13.5 & 2.05 \\
\hline
\end{tabular}

a Nuclear volumes for spectes without sensitivity data from A. H. Sparrow \& A. F. Nauman, unpublished; for species with sensitivity data, from Sparrow, Howard, Cowie, Schwemer Nauman (1975).

bata from Sparrow, Howard, Cowle, Schwemmer \& Nauman (1975).

cFrom the 1iterature. All other counts made or confirmed in A. H. Sparroj laboratory. 
Table 4

Chromosome number, nuclear yolume, ICV and sensitivity (LD50) of sporophytes or gametophytes of $11 \mathrm{species}$ of lower plants.

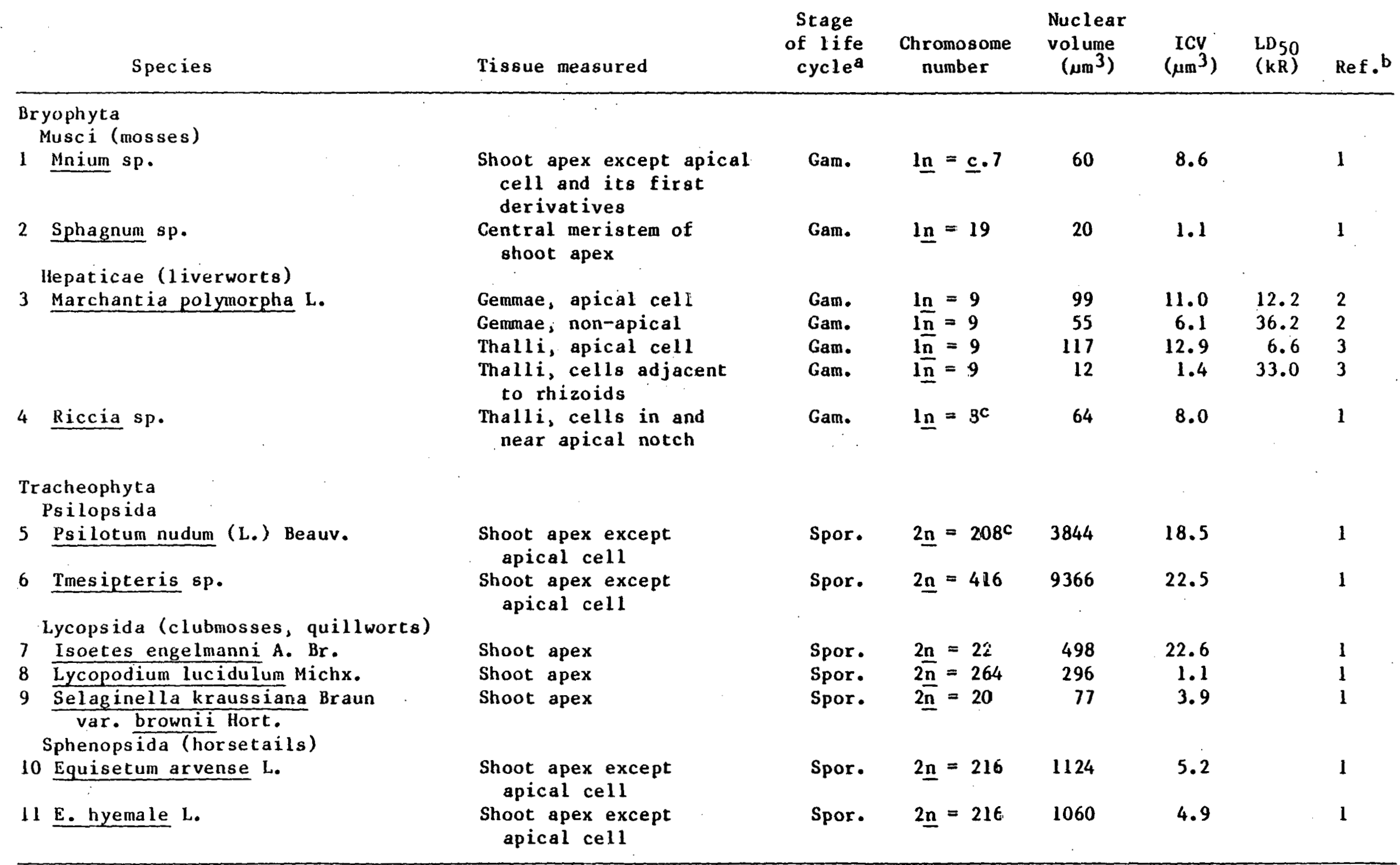

aGametophyte or sporophyte.

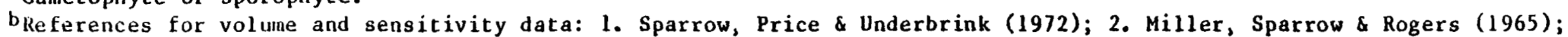

3. Miller \& Sparrow (1965).

Chromosome counts made in A. H. Sparrow laboratory. All others from the literature. 
fanlly, class, Lfe span, ploldy, chromosome muber, nuclear volume, interghase chromosome volume (ICV), genome volume,

estimated 3C DNA consent, and estimated $L_{50}$ of 780 spectes of herbaceousa anglosperms

\begin{tabular}{|c|c|c|c|c|c|c|c|c|c|c|}
\hline & Spectesb & Faglly & $\mathrm{Class}^{\mathrm{c}}$ & $\begin{array}{l}\text { Life } \\
\operatorname{spand}^{\mathrm{d}}\end{array}$ & $\begin{array}{l}\text { Ploidy and } \\
\text { chromosome } \\
\text { number(2n)e }\end{array}$ & $\begin{array}{l}\text { Nuclear } \\
\text { volumef } \\
\left(\mathrm{Hm}^{3}\right)\end{array}$ & $\begin{array}{r}\text { ICVB } \\
\left(\mu \square^{3}\right)\end{array}$ & $\begin{array}{c}\text { Genome } \\
\text { vol ume } \\
\left(\mu \mathrm{mot}^{\mathrm{3}}\right)\end{array}$ & $\begin{array}{l}\text { Est. } \\
\frac{3 C \text { DNA }}{(\mathrm{pg})}\end{array}$ & $\begin{array}{l}\text { Est. } \\
\text { L.D } \text { D }_{50} \\
(k R)\end{array}$ \\
\hline 1. & Aclililea collina Beck & Compositae & Dic. & Per: & $4 x=36$ & 349 & 9.7 & 87 & 23 & 7.8 \\
\hline 2 . & Actaca alba (L.) MIII. & Ranunculaceae & Dic. & Per. & $2 x=16$ & $28 B$ & 18.0 & 144 & 19 & 4.2 \\
\hline 3. & A. rubra (Alt.) willd. & Ranunculaceae & Dic. & Per. & $2 x=16$ & 352 & 22.0 & 176 & 24 & 3.4 \\
\hline 4. & Aegflops speltoldes Tausch. & Gramineae & Mon. & Ann. & $2 x=14$ & 234 & 16.7 & 117 & 16 & 4.5 \\
\hline 5. & A. squarrosa l. var. typlca & GramIneae & Mon. & Ann. & $2 x=14$ & 222 & 15.8 & 111 & 15 & 4.8 \\
\hline 6. & Agapanthus gooreanus Hort. & LIllaceae & Mon. & Per. & $2 x=30$ & 885 & 29.5 & 443 & 59 & 2.6 \\
\hline 7. & Agave amaniensis Trel. \& Nowell & Amaryllidaceae: & Mon. & Per. & $2 x=60$ & 387 & 6.5 & 194 & 26 & 11.6 \\
\hline 8. & A. rigdda Mill. & Amaryll Idacear & Mon. & Per. & $c .5 x=149$ & 712 & 4.8 & c. 142 & 48 & 15.7 \\
\hline 9. & Agropyron sp. liybrld & Granl neae & Mon. & Per. & $3 x=21$ & 225 & 10.7 & -75. & 15 & 7.1 \\
\hline 10. & A. cristatum (L.) Gaertn. & Gramineae & Mon. & Per. & $2 x=14^{k}$ & 290 & 20.7 & 145 & 19 & 3.7 \\
\hline 11. & A. Internedlua (llost) Beauv. & Gramlneae & Mon. & Per. & $6 x=42$ & 432 & 10.3 & 72 & 29 & 7.3 \\
\hline 12. & $\begin{array}{l}\text { A. Erachycaulum (Link) Malte var. } \\
\text { Blaucun (Pease o Moore) Malte }\end{array}$ & Gramtneae & Mon. & Per. & $4 x=28$ & 338 & 12.1 & 85 & 23 & 6.2 \\
\hline 13. & Aletris farinosa $\mathrm{L}$. & Amaryll1daceae & Mon. & Per. & $2 x=26 k$ & 210 & 8.1 & 105 & 14 & 9.3 \\
\hline 14. & A111um ampeloprasum L. (Uncertalin) & LIIfaceae & Mon. & Per. & $6 x=48^{k}$ & 2097 & 43.7 & 349 & 140 & 1.7 \\
\hline 15. & A. cepa L.cv. Excel & L11 Laceae & Mon. & Per. & $2 x=16^{k}$ & 628 & 39.3 & 314 & 42 & 1.9 \\
\hline 16. & A. cepa 1. cv. Yamaguch1-Kohdaka & Lllaceae & Mon. & Per. & $2 x=16$ & 612 & 38.2 & 306 & 41 & 2.0 \\
\hline 17. & $\begin{array}{l}\text { A.cepa L. cv. } \\
\text { Yellow Sweet Spanish }\end{array}$ & Llllaceae & Mon. & Per. & $2 x=16$ & 649 & 40.6 & 325 & 49 & 1.7 \\
\hline 18. & $\frac{\text { A. cepa L. X A. fisculosum L. }}{\text { cv. Bel rsville Bunching }}$ & L11 laceae & Mon. & Per. & $4 x=32$ & 662 & 20.7 & 166 & 44 & 3.7 \\
\hline 19. & A. cernumin Roth & L11 1aceae & Mou. & Per. & $2 x=14^{k}$ & 639 & 45.7 & 320 & 43 & 1.7 \\
\hline 20. & A. fistulosum L. cv. kujyo & L1licaeae & Mon. & Per. & $2 x=16$ & 472 & 29.5 & 236 & 32 & 2.6 \\
\hline 21. & A. porruat $\mathrm{L}$. cv. Broad london & Llllaceae & Mon. & Per. & $4 x=32$ & 1111 & 34.72 & 278 & 74 & 2.2 \\
\hline 22. & A. sactivin 1. & Llllaceae & Mon. & Per. & $2 x=16$ & 532 & 33.28 & 266 & 36 & 2.3 \\
\hline 23. & A. Scorodoprasum $L$. & LIllaceae & Mon. & Per. & $6 x=48 k$ & 2207 & 45.98 & 368 & 148 & 1.6 \\
\hline 24. & A. senescens $\mathrm{L}$. & Lllaceae & Mon. & Per. & $4 x=32$ & 870 & 27.19 & 217 & 58 & 2.8 \\
\hline 25 . & A. Eangutfenim Regel & Lllaceae & Mon. & Per. & $6 x=48$ & 825 & 17.18 & 137 & 55 & 4.4 \\
\hline 26. & A. Cricoccum Att. & Lll lacede & Mon. & Per. & $2 x=16^{k}$ & 850 & 53.11 & 212 & 57 & $1.4^{\circ}$ \\
\hline 27. & A. Cuberosuo koteler & Lillaceae & Mon. & Per. & $4 x=32$ & 803 & 25.08 & 201 & 54 & 3.0 \\
\hline 28. & A. vinea]e l. & LH iaceae & Mon. & Per. & $4 x=32^{k}$ & 682 & 21.32 & 171 & 46 & 3.5 \\
\hline 29. & Alge brevifolia Mill. & L11 laceae & Mon. & Per. & $2 x=14$ & 917 & 65.49 & 458 & 61 & 1.1 \\
\hline 30. & $\begin{array}{l}\text { Alternanthera plit loxerofdes } \\
\text { Griseb. }\end{array}$ & Awa ranthaceae & Dic. & Per. & $2 x=94^{k}$ & 259 & 2.75 & -- & 17 & 27.0 \\
\hline 31. & Althaea rosea I. & Malvaceae & Dic. & B1. & $6 x=42$ & 164 & 3.90 & 27 & 11 & 19.4 \\
\hline 32. & Amarantlius liybridus L. & Awaranthaceae & Dic. & Ann. & $4 x=32$ & 121 & 3.80 & 30 & 8 & 19.9 \\
\hline 33. & Anaryllis belladonna o. & Anaryll1daceat: & Mon. & Per. & $2 x=22$ & 1243 & 56.51 & 622 & 83 & 1.3 \\
\hline 34 . & Ansinck 1a tessellaca cray & Boraginaceae & Dic. & Ann. & $2 x=24$ & 182 & 7.57 & 91 & 12 & 9.9 \\
\hline 35. & Andeyclus off tcl narum llayue & Compositae & Dic. & Ann. & $2 x=18$ & 197 & 10.96 & 99 & 13 & 6.9 \\
\hline 36. & Andropogon barbinodts lag. & GramIneae & Mon. & Per. & $18 x=180$ & 164 & 0.91 & 9 & 11 & 84.0 \\
\hline 37. & A. gerardi VItm. & Gramineae & Mon. & Per. & $6 x=60$ & 147 & 2.46 & 25 & 10 & 30.2 \\
\hline 38. & A. scopartus Miclix. & Gramineae & Mon. & Per. & $4 x=40$ & 254 & 6.36 & 64 & 17 & 11.8 \\
\hline 39. & Ane Tlena acqu1 noctiale Kunth & Commel fuaceae & Mon. & Per. & $6 x=54 k$ & 398 & 7.38 & 66 & 27 & 10.2 \\
\hline 40 . & A. benInense Kunth ssp. beniluense & Comel Inaceae & Main. & Per. & $4 x=52^{k}$ & 250 & 4.80 & 62 & 17 & 15.7 \\
\hline 41. & A. beninense kunth spl. Beonensis & Commel Inaceae & Mon. & Per. & $6 x=78^{k}$ & 470 & 6.03 & 78 & 31 & 12.6 \\
\hline
\end{tabular}


Table 5 (cont.)

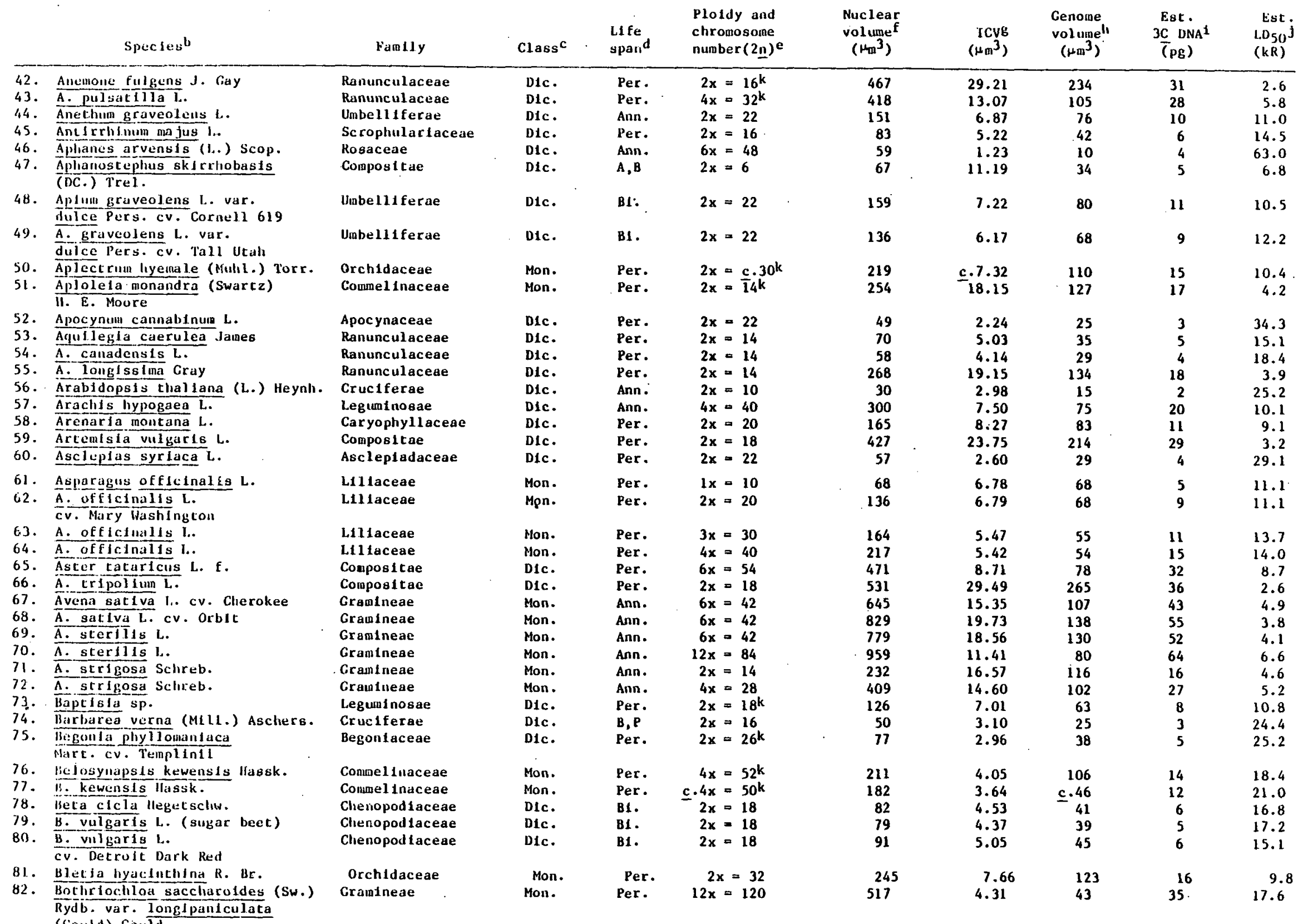


Tables (cont.)

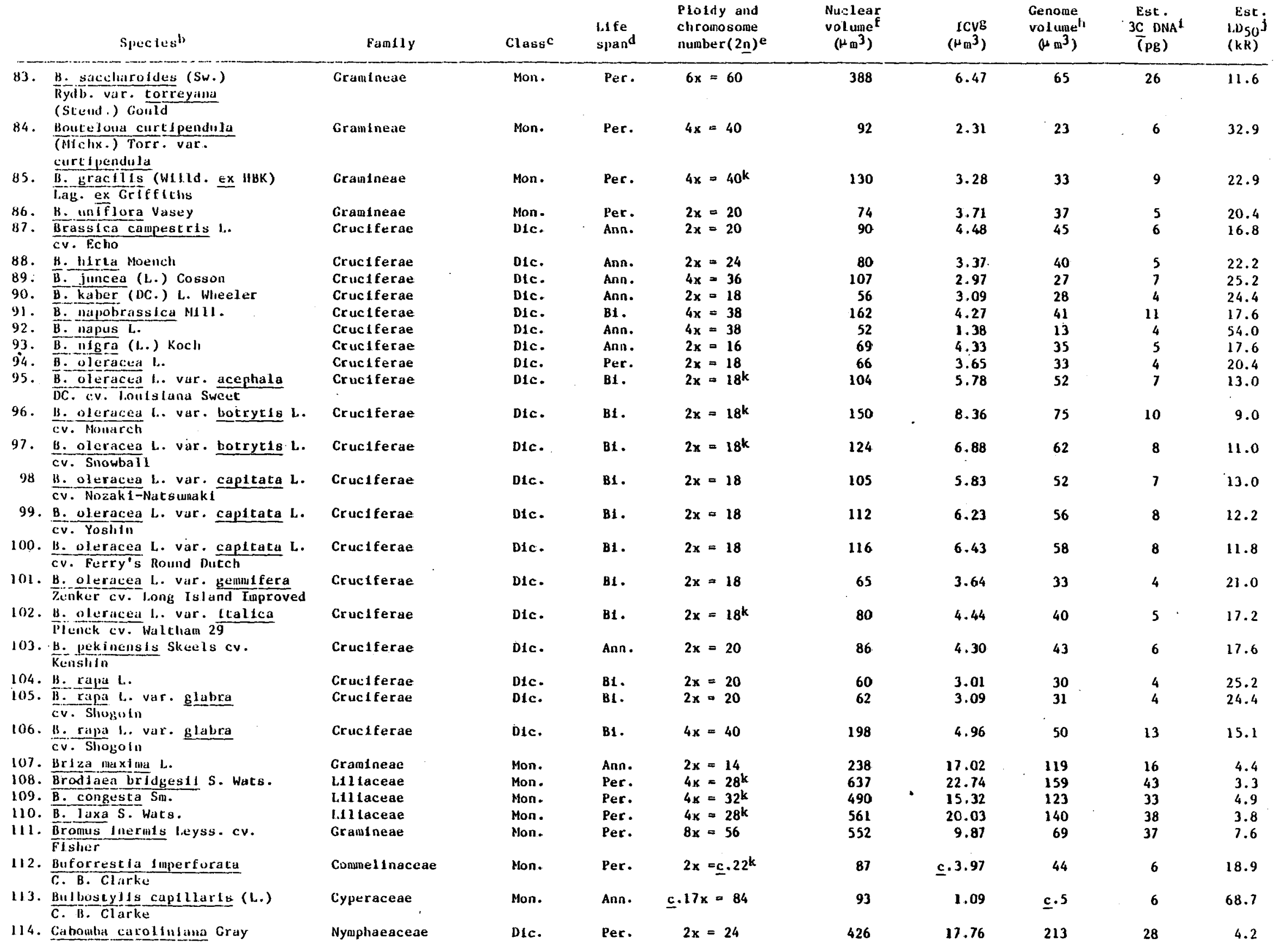


'tsble 5 (cont.)

\begin{tabular}{|c|c|c|c|c|c|c|c|c|c|}
\hline spectesb & Fant1y & Class $\mathrm{c}$ & $\begin{array}{l}\text { Life } \\
\text { spand }\end{array}$ & $\begin{array}{l}\text { Ploldy and } \\
\text { chronosotne } \\
\text { number }(2 n)^{e}\end{array}$ & $\begin{array}{l}\text { Nuclear } \\
\text { volumef } \\
\left(\mu_{\mathrm{m}} \mathrm{m}^{3}\right)\end{array}$ & $\begin{array}{r}\text { ICVB } \\
\left(\mu_{m^{3}}\right)\end{array}$ & $\begin{array}{l}\text { Cenome } \\
\text { vol ume } \\
\left(1+m^{3}\right)\end{array}$ & $\begin{array}{l}\text { Est. } \\
\frac{3 C}{(P B)} \text { DNA } 1\end{array}$ & $\begin{array}{l}\text { Est. } \\
\text { L.Dsoj } \\
(k R)\end{array}$ \\
\hline 115. Callista clegans Alexander & Commel Inaceac & Mon. & Par. & $2 x=12^{k}$ & 456 & 38.02 & 228 & 31 & 2.0 \\
\hline 116. $\bar{c}$ fragrans (tind1.) Woodson & Commelinaceae & Mon. & Per. & $2 x=12^{k}$ & 580 & 48.31 & 290 & 39 & 1.6 \\
\hline 117. $\frac{\text { C. fragrans (LIndl.) Woodson }}{\text { cv. Melnickoff }}$ & Comnel Inaceae & Mon. & Per. & $2 \mathrm{x}=12^{k}$ & 611 & 50.94 & 306 & 41 & 1.5 \\
\hline 118. C. Inacdouga111 M1 randa & Commel Inaceae & Mon. & Per. & $2 x=12^{k}$ & 337 & 28.09 & 169 & 23 & 2.7 \\
\hline 119. $\bar{c}$ repens $L$. & Commel Inaceae & Mon. & Per. & $4 x=24^{k}$ & 663 & 27.62 & 166 & 44 & 2.7 \\
\hline 120. $\overline{\mathrm{C}}$. Soconuscensls Matuda & Commel inaceae & Mon. & Per. & $2 x=12^{k}$ & 635 & 52.87 & 317 & 42 & 1.4 \\
\hline 121. $\bar{C}$. Celuantepecana Matuda & Conmelinaceae & Mon. & Per. & $2 x=12^{k}$ & 480 & 39.99 & 240 & 32 & 1.9 \\
\hline 122. Calochortus macrocarpus Dougl. & Liltaceae & Mon. & Per. & $2 x=14$ & 346 & 24.72 & 173 & 23 & 3.1 \\
\hline 123. C. splendens Dong1. ex Benth. & L.11 aceae & Mon. & Per. & $2 x=14$ & 428 & 30.59 & 214 & 29 & 2.5 \\
\hline 124. Calonyct lon aculeatum (L.) House & Convolvulaceae & Dic. & Per. & $2 x=30$ & 166 & 5.55 & 83 & 21 & 13.5 \\
\hline 125. Cantelina alyssum Theil. & Cruclferae & Dic. & Ann. & $6 x=42$ & 77 & 1.83 & 13 & 5 & 39.8 \\
\hline 126. Campe11a zanonla (L.) IlbK & Commel Inaceae & Mon. & Per. & $2 x=16^{k}$ & 578 & 36.13 & 289 & 39 & 2.1 \\
\hline 127. Capse11a bursa-pastoris & Cruciferae & Dic. & Ann. & $4 x=32$ & 67 & 2.07 & 17 & 4 & 36.0 \\
\hline 128. Capsicum frulcscens l.. & Solanaceae & Dic. & Ann. & $2 x=24$ & 155 & 6.45 & 77 & 10 & 11.6 \\
\hline 129. Carex pensyluanlca l.an. & Cyperaceae & Mon. & Per. & $6 x=36$ & 101 & 2.80 & 17 & 7 & 27.0 \\
\hline 130. Carriclicera velia oc. & Cruciferae & Dic. & $?$ & $2 x=16$ & 51 & 3.19 & 26 & 3 & 23.6 \\
\hline 131. Carthamus tinctortus L. & Compositae & Dic. & Ann. & $2 x=24$ & 212 & 8.84 & 106 & 14 & 8.6 \\
\hline 132. C. tinctorfus L. cv. Chla & Compositae & Dic. & Ann. & $4 x=48$ & 512 & 10.68 & 128 & 34 & 7.1 \\
\hline 133. $\bar{c}$ tnetorlus L. cv. India & Compositae & Dic. & Ann. & $2 x=24$ & 194 & 8.09 & 97 & 13 & 9.3 \\
\hline 134. C. E1nctorIus L. $(\mathrm{N}-10)$ & Compositae & Dic. & Ann. & $2 x=24$ & 199 & 8.28 & 99 & 13 & 9.1 \\
\hline 135. C. tinctorlus L. (US-10) & Compositae & Dic. & Ann. & $2 x=24$ & 280 & 11.66 & 140 & 19 & 6.5 \\
\hline 136. Carconema parviflorum llassk. & Commel Inaceae & Mon. & Per. & $2 x=24 k$ & 163 & 6.78 & 81 & 11 & 11.1 \\
\hline 137. c. philydrotdes F. Muell. & Commel1naceae & Mon. & Per. & $2 x=24 k$ & 129 & 5.39 & 65 & 9 & 14.0 \\
\hline 1.38. $\bar{C}$. splcatun $R . B r$ & Commel Inaceae & Mon. & Per. & $4 x=48^{k}$ & 210 & 4.38 & 53 & 14 & 17.2 \\
\hline 139. Cauloplyilum Ehalictroldes (L.) & Berber 1daceae & Dic. & Per. & $2 x=16$ & 372 & 23.25 & 186 & 25 & 3.2 \\
\hline 140. Cerasclum tomentosum I.. & Caryophyllaceae & Dic: & Per. & $8 x=72 k$ & 65 & 0.91 & 8 & 4 & 84.0 \\
\hline 141. Ceratophyllum demersum l.. & Ceratophyllaceae & Dic. & Per. & $2 x=24$ & 133 & 5.54 & 67 & 9 & 13.7 \\
\hline 142. C. submersum L. & Ceratophyllaceae & Dic. & Per. & $6 x=72^{k}$ & 173 & 2.41 & 29 & 12 & 31.5 \\
\hline 143. Chaenacts sant lany Gray & Compositae & Dic. & Ann. & $2 x=14$ & 155 & 11.09 & 78 & 10 & 6.8 \\
\hline 144. Chenopodt um album L. & Chenopod 1aceae & Dic. & Ann. & $4 x=36^{k}$ & 159 & 4.41 & 40 & 11 & 17.2 \\
\hline 145. Chionodoxa luctliate Hoiss. & Lll1aceae & Mon. & Per. & $2 x=18$ & 382 & 21.21 & 191 & 26 & 3.6 \\
\hline 146. Chloropliytum elatum R. Br. & L11 Laceae & Mon. & Per. & $4 x=28$ & 751 & 26.83 & 188 & 50 & 2.8 \\
\hline 147. Chrysanthemun sp. & Conpositae & Dic. & Per. & $c \cdot 15 x=138^{k}$ & 1333 & 9.66 & c. 89 & 89 & 7.8 \\
\hline 148. C. sp. cv. May Queen (uncertaln) & Compositae & Dic. & Per. & $4 x=36^{k}$ & 489 & 13.59 & 122 & 33 & 5.6 \\
\hline 149. $\bar{c} . \operatorname{arct} I$ cum $L$. & Compositae & Dic. & Per. & $c .7 x=64 k$ & 675 & 10.54 & c. 96 & 45 & 7.2 \\
\hline 150. c. corymbosum & Compositae & Dic. & Per. & $2 x=18$ & 270 & 15.00 & -135 & 18 & 5.0 \\
\hline 151. c. indicum $\mathrm{L}$. & Compositae & Dic. & Per. & $6 x=54$ & 358 & 6.62 & 60 & 24 & 11.5 \\
\hline 152. $\bar{c}$. 1rcultanum Turcz. & Compositae & Dic. & Per. & $4 x=36$ & 462 & 12.84 & 116 & 31 & 5.9 \\
\hline 153. C. lacustre Brot. & Compositae & Dic. & Per. & $22 x=198$ & 2709 & 13.68 & 123 & 181 & 5.5 \\
\hline 154. C. lencanthenum I.. & Compositae & Dic. & Per. & $2 x=18^{k}$ & 286 & 15.87 & 143 & 19 & 4.8 \\
\hline 155. C. nipponfcum Mat sum. & Compusitae & Dic. & Per. & $2 x=18$ & 318 & 17.68 & 159 & 21 & 4.3 \\
\hline 156. c. sonare & Compost tae & DIc. & Per. & c. $9 x=80$ & 773 & 9.67 & c. 86 & 52 & 7.8 \\
\hline 157. $\bar{c}$. yezoense Maekawa & Compositae & Dic. & Per. & $\underline{c} \cdot 6 x=56^{k}$ & 761 & 13.59 & c. 127 & 51 & 5.6 \\
\hline 158. Clirysopsis falcata (Pursh) Ell. & Compositae & Dic. & Per. & $2 x=18^{k}$ & 200 & 11.14 & 100 & 13 & 6.8 \\
\hline 159. c. thariana (L.) Elil. & Compositae & Dic. & Per. & $2 x=24 k$ & 353 & 14.70 & 176 & 24 & 5.1 \\
\hline 160. Cicer arfétinua L. & Leguminosae & Dic. & Ann. & $2 x=16$ & 105 & 6.59 & 53 & 7 & 11.5 \\
\hline
\end{tabular}


Table 5 (cont.)

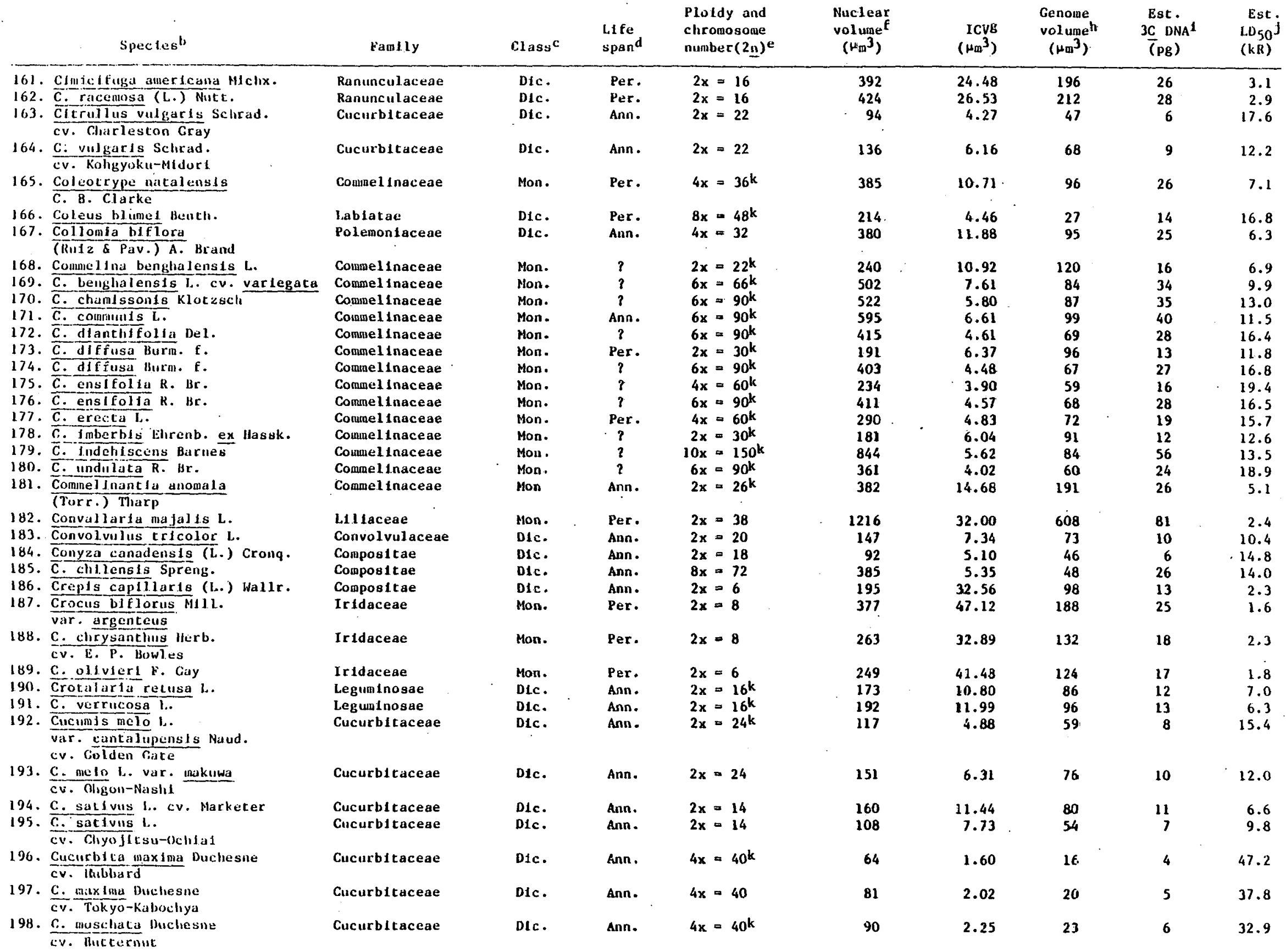


'rable 5 (cont.)

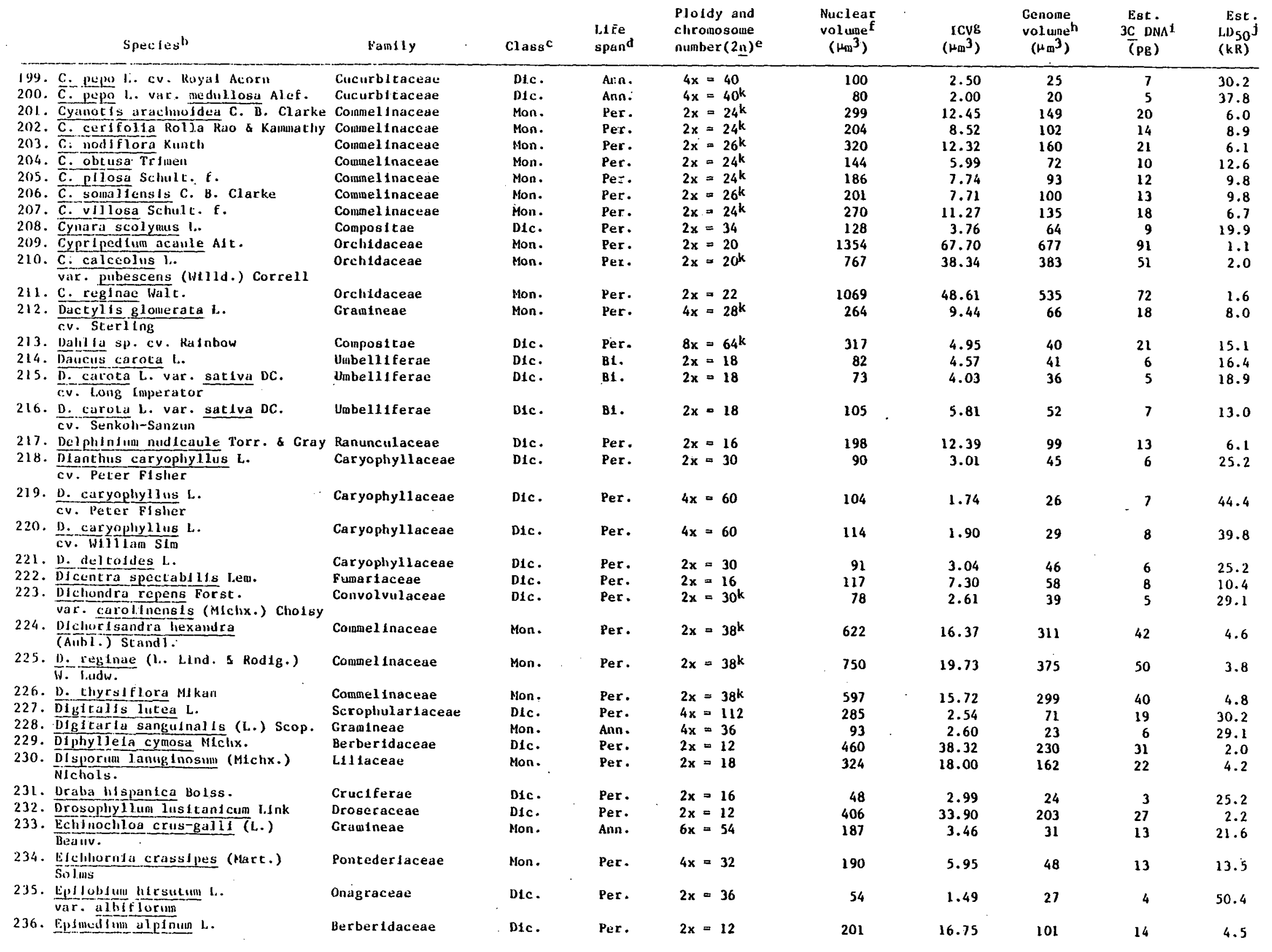


trable 5 (cunt.)

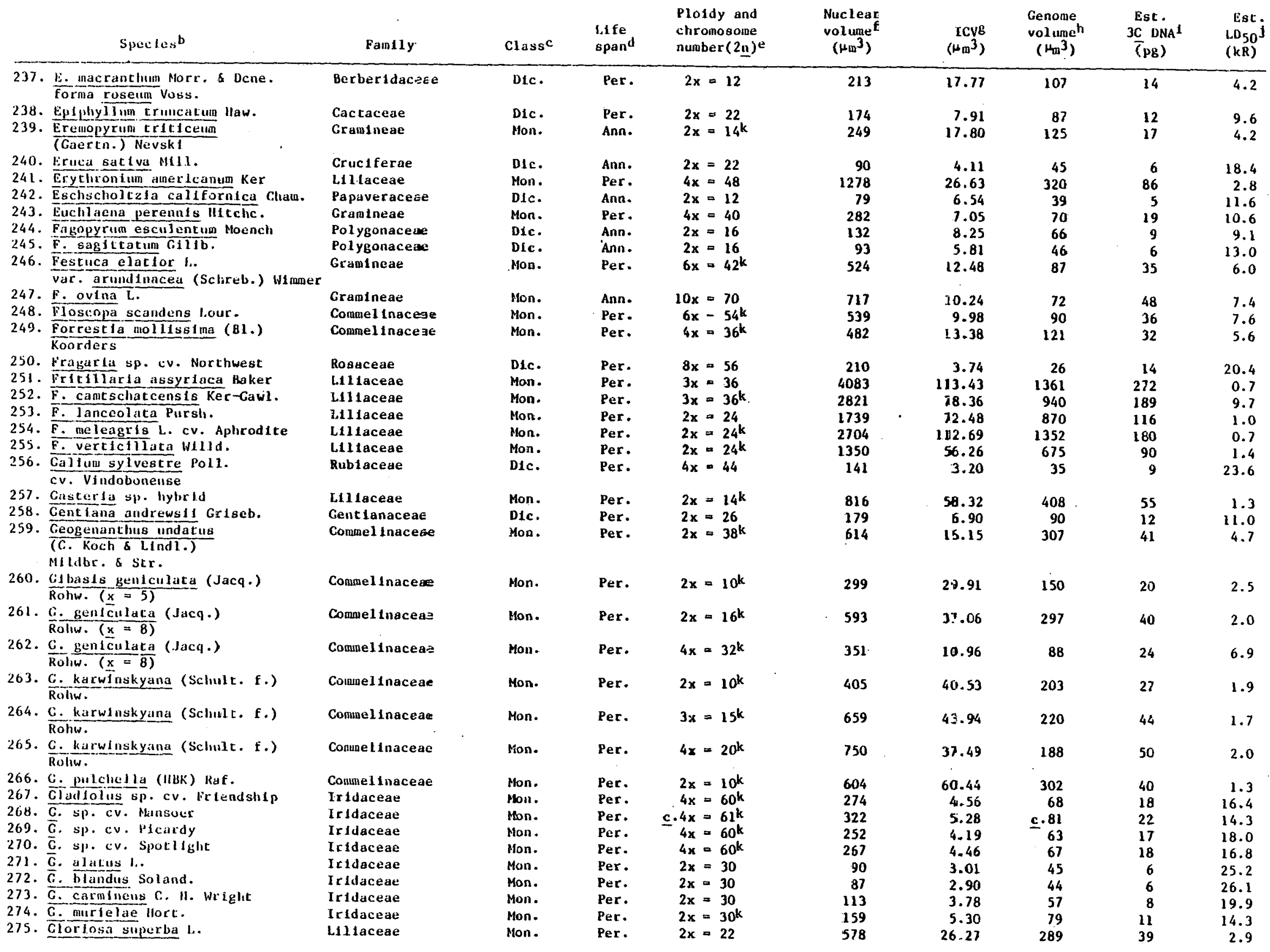


I'able 5 (cont.)

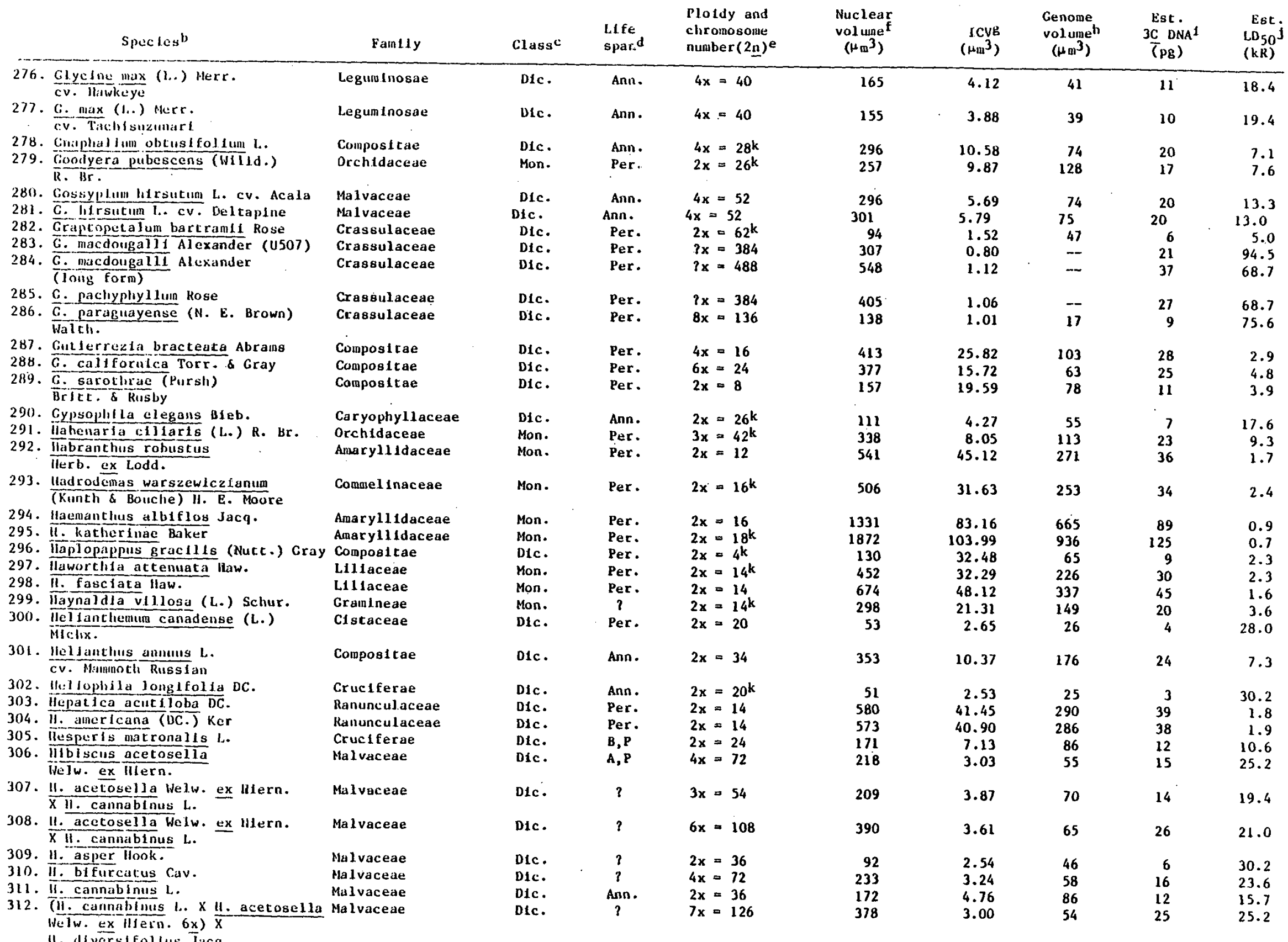




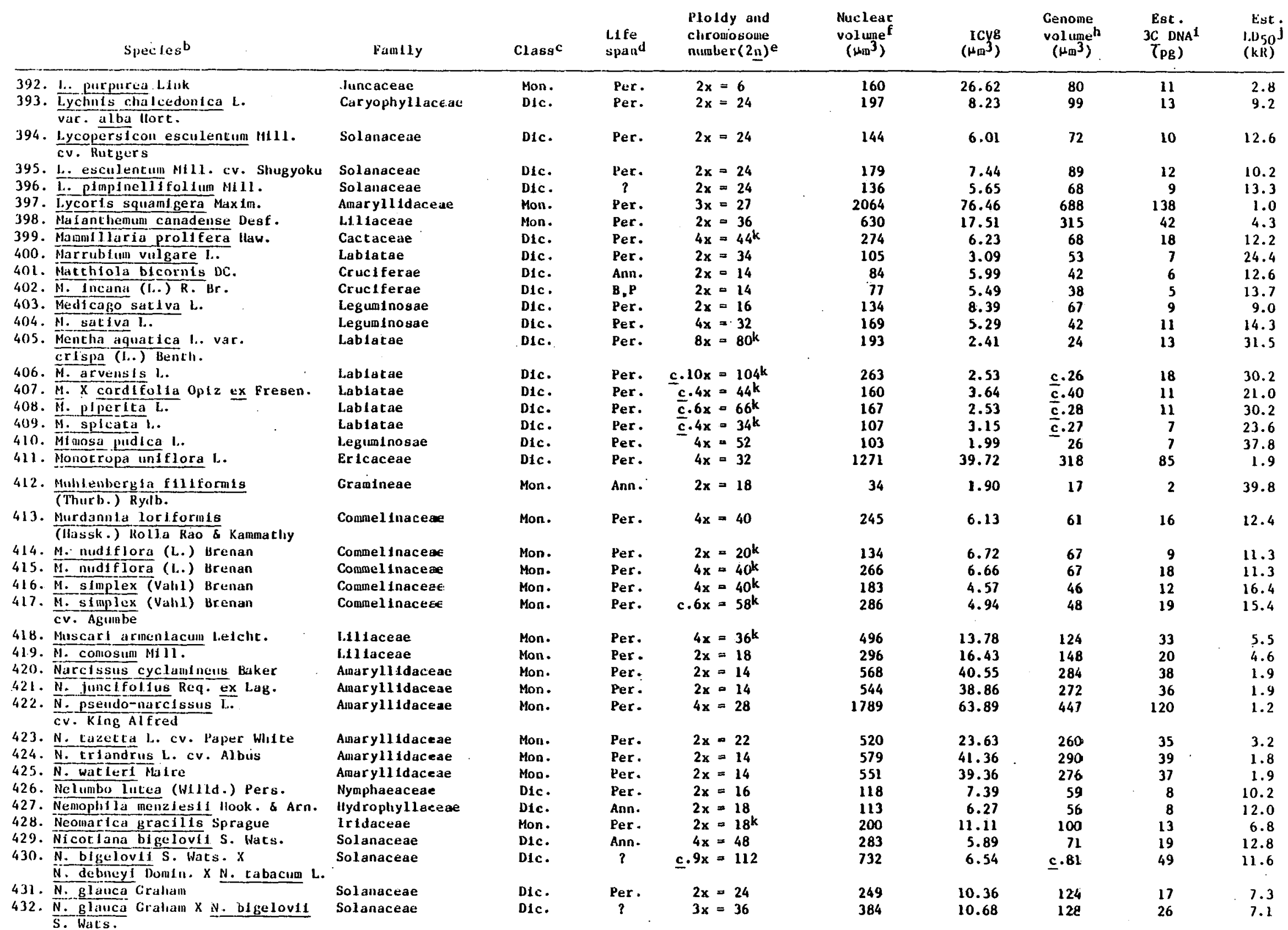


l'able 5 (cont.)

\begin{tabular}{|c|c|c|c|c|c|c|c|c|c|}
\hline Speclesb & Eamily & $\mathrm{Class}{ }^{\mathrm{c}}$ & $\begin{array}{l}\text { Life } \\
\text { spand }\end{array}$ & $\begin{array}{l}\text { Ploldy and } \\
\text { chromosome } \\
\text { number }(2 n)^{e}\end{array}$ & $\begin{array}{l}\text { Nuclear } \\
\text { vol ume } \\
\left.\left(\mu_{m}\right)^{3}\right)\end{array}$ & $\begin{array}{r}\text { ICvg } \\
\left.\left(\mu_{3}\right)^{3}\right)\end{array}$ & $\begin{array}{l}\text { Genome } \\
\text { volume } \\
\left(\mu_{\mathrm{m}^{3}}\right)\end{array}$ & $\begin{array}{l}\text { Esc. } \\
3 C \text { DNA } 1 \\
\text { (pg) }\end{array}$ & $\begin{array}{l}\text { Est } \\
1 . D_{50} j \\
(k R)\end{array}$ \\
\hline $\begin{array}{l}\text { 433. N. glauca Graham } x \\
\text { N. langsdorefil Sclirank }\end{array}$ & Solanaceae & Dic. & $?$ & $\underline{c} \cdot 4 x=42$ & 320 & 7.61 & $\underline{c} \cdot 80$ & 21 & 9.9 \\
\hline 434. $\frac{\bar{N} \cdot \text { Blutelnosa la }}{\text { N. glauca Graham }} \times$ & Sol anaceae & Dic. & $?$ & $4 x=48$ & 322 & 6.71 & 81 & 22 & 11.3 \\
\hline 435. N. langsdorffil Schrank & Solanaceae & Dic. & Ann. & $2 x=18$ & 156 & 8.68 & 78 & 10 & 8.7 \\
\hline 436. N. rustica L. & Solanaceae & Dic. & Ann. & $4 x=48$ & 202 & 4.21 & 50 & 14 & 18.0 \\
\hline $\begin{array}{l}\text { 437. N. X sanderae llorc. ex } \\
\text { Gard. (var fegated derfvactve) }\end{array}$ & Solanaceae & Dic. & Ann. & $2 x=18$ & 162 & 8.99 & 81 & 11 & 8.4 \\
\hline 438. N. X sanderac Hort. ex & Sol anaceae & Dic. & Ann. & $4 x=36$ & 301 & 8.35 & 75 & 20 & 9.0 \\
\hline 439. N. tabacim L. (6290 Short) & Solanaceae & Dic. & Ann. & $4 x=48$ & 343 & 7.14 & 86 & 23 & 10.6 \\
\hline 440. N. Cahacum L. (6291 Tall) & Solanaceae & D1c. & Ann. & $4 x=48$ & 292 & 6.09 & 73 & 20 & 12.4 \\
\hline 441. N. rahacum L. cv. HIscousta 38 & Solanaceae & Dic. & Ann. & $4 x=48$ & 425 & 8.86 & 106 & 28 & 8.5 \\
\hline 442. $\frac{\text { N1ge1la damiscena }}{\text { Cv. Miss Jekyl1 }}$ & Ranuiculaceae & Dic. & Ann. & $2 x=12$ & 379 & 31.55 & 189 & 25 & 2.4 \\
\hline $\begin{array}{l}\text { 443. N. saclva L. } \\
\text { 444. Nuphar advena (Alt.) Alt. f. }\end{array}$ & $\begin{array}{l}\text { Ranunculaceae } \\
\text { Nymphaeaceae }\end{array}$ & $\begin{array}{l}\text { Dic. } \\
\text { Dic. }\end{array}$ & Aun. & $2 x=12$ & 414 & 34.49 & 207 & 28 & 2.2 \\
\hline 445. N. Sagitetfollual (Walt.) Pursh & Nymphaeaceae & $\begin{array}{l}\text { Dic. } \\
\text { Dic. }\end{array}$ & $\begin{array}{l}\text { Per. } \\
\text { Per. }\end{array}$ & $\begin{array}{l}2 x=34 \\
2 x=34\end{array}$ & 352 & 10.36 & 176 & 24 & 7.3 \\
\hline $\begin{array}{l}\text { 446. Nympliacai capensis Thunb. } \\
\text { var. zanzibariens Is Casp. }\end{array}$ & Nymphaeaceae & $\begin{array}{l}\text { Dic. } \\
\text { Dic. }\end{array}$ & $\begin{array}{l}\text { Per. } \\
\text { Per. }\end{array}$ & $\begin{array}{l}2 x=34 \\
2 x=28\end{array}$ & $\begin{array}{r}394 \\
90\end{array}$ & $\begin{array}{r}11.60 \\
3.20\end{array}$ & $\begin{array}{r}197 \\
45\end{array}$ & $\begin{array}{r}26 \\
6\end{array}$ & $\begin{array}{r}6.5 \\
23.6\end{array}$ \\
\hline 447 N. gl gantea llook. & Nymphaeaceae & Dic. & Per. & $2 \mathrm{x}=\mathrm{c} \cdot 22^{\mathrm{k}}$ & 74 & $c .3 .36$ & 37 & 5 & 22.2 \\
\hline & Nymphaeaceae & Dic. & Per. & $6 x=\overline{8} 4$ & 114 & -1.36 & 19 & 8 & 54.0 \\
\hline 450. Ornithogabum direns lind & $\begin{array}{l}\text { Onagraceae } \\
\text { LIllaceae }\end{array}$ & $\begin{array}{l}\text { Dic. } \\
\text { Mon. }\end{array}$ & $\begin{array}{l}\text { Bi. } \\
\text { Per. }\end{array}$ & $\begin{array}{l}2 x=14 \\
2 x=6\end{array}$ & $\begin{array}{l}168 \\
317\end{array}$ & $\begin{array}{l}12.01 \\
32.78\end{array}$ & $\begin{array}{r}84 \\
158\end{array}$ & 11 & 6.3 \\
\hline 451. Oryza sativa l.. (8970-S) & Gramfneae & Mon. & Ans. & $2 x=24$ & 74 & $\begin{array}{r}32.68 \\
3.07\end{array}$ & $\begin{array}{r}158 \\
37\end{array}$ & $\begin{array}{r}21 \\
5\end{array}$ & $\begin{array}{r}1.4 \\
24.4\end{array}$ \\
\hline 452. 0. Sativa L. cv. Nolieln No. 8 & Granineae & Mon. & Ann. & $2 x=24$ & 77 & 3.19 & 38 & 5 & 23.6 \\
\hline 453. 0. sativa L. cv. Zenleh & Cramineae & Mon. & Ann. & $2 x=24$ & 71 & 2.98 & 36 & 5 & 25.2 \\
\hline 454. Oxalis martlana Zuce. & Oxal1daceae & Dic. & Per. & $2 x=14$ & 91 & 6.49 & 45 & 6 & 11.6 \\
\hline 455. 0. stricka l.. & Oxalidaceae & Dic. & Per. & $4 x=24$ & 112 & 4.68 & 28 & 8 & 16.1 \\
\hline 456. Patomla sp. cu. Fell1x Crousse & Ranunculaceae & Dic. & Per. & $2 x=10^{k}$ & $36 B$ & 36.76 & 184 & 25 & 2.1 \\
\hline 457. Palisota alberty L. Centll & Coumel Inaceae & Mon. & Per. & $4 x=40^{k}$ & 611 & 15.28 & 153 & 41 & 4.9 \\
\hline 458. $\overline{\mathrm{p}}$-barter llook. $\mathrm{f}$ & Complinaceae & Mon. & - Per. & $8 x=80^{k}$ & 886 & 11.07 & 111 & 59 & 6.8 \\
\hline 459. p. elizabethae L. Centil & Commel Inaceae & Mon. & Per. & $4 x=40^{k}$ & 554 & 13.85 & 138 & 37 & 5.4 \\
\hline 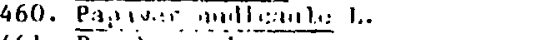 & Piapaveraceae & Dic. & Per. & $2 x=14$ & 121 & 8.61 & 60 & 8 & 8.8 \\
\hline 461. P. rhoeas l.. & Papaveraceae & Dic. & Ann. & $2 x=14$ & 156 & 11.13 & 78 & 10 & 6.8 \\
\hline 462. Paspalum d1 lacatum Poir. & Gramlneae & Mon. & Per. & $4 x=40$ & 116 & 2.90 & 29 & 8 & 26.1 \\
\hline 463. P. dilatatum Polr. & Gramineae & Mon. & Per. & $5 x=50$ & 147 & 2.94 & 29 & 10 & 26.1 \\
\hline 464. P. distlchum l. & Granineae & Mon. & Per. & $60 x=60$ & 110 & 1.84 & 18 & 7 & 42.0 \\
\hline 465. P. Elorddanum Michx. & Gramineae & Mon. & Per. & $18 x=180$ & $\$ 92$ & 3.29 & 33 & 40 & 22.9 \\
\hline 466. P. urv11let Stend. & Gramineae & Mon. & Per. & $4 k=40$ & 108 & 2.71 & 27 & 7 & 28.0 \\
\hline 467. Past Inaca saclva $L$. & Unbell Iferae & Dic. & B1. & $2 x=22$ & 154 & 7.00 & 77 & 10 & 10.8 \\
\hline 468. Pelargonlum sp. & Geranlaceae & D1c. & Per. & $1 x=9 k$ & 80 & 8.94 & 80 & 5 & 8.5 \\
\hline 469. $\overline{\mathrm{P}} \cdot \mathrm{sp} \cdot \mathrm{cv} \cdot$ Manie & Geranlaceae & Dic. & Per. & $4==36^{k}$ & 274 & 7.62 & 69 & 18 & 9.9 \\
\hline 470. P. sp. cv. Purple Heart & Geranlaceae & Dic. & Per. & $2 x=18^{k}$ & 156 & 8.69 & 78 & 11 & 8.7 \\
\hline 471. Peltandra virgiufea (L.) & Araceae & Mon. & Per. & $10 x=110^{k}$ & 504 & 4.58 & 50 & 34 & 16.4 \\
\hline 472. Pennlsecum Hiancun $\mathrm{K}$. Hr. & Gramineae & Mon. & Ann. & $2 x=14$ & 149 & 10.62 & 74 & 10 & 7.1 \\
\hline 473. Perllla frutescens Britc. & Lablatae & Dic. & Ann. & $2 x=40^{k}$ & 227 & 5.68 & $\overline{-}$ & 15 & 13.3 \\
\hline 4/4. Petroselinum crtspum (MII.) & Umbelliferae & Dic. & B1. & $2 x=22^{k}$ & 102 & 4.62 & 51 & 7 & 16.4 \\
\hline
\end{tabular}




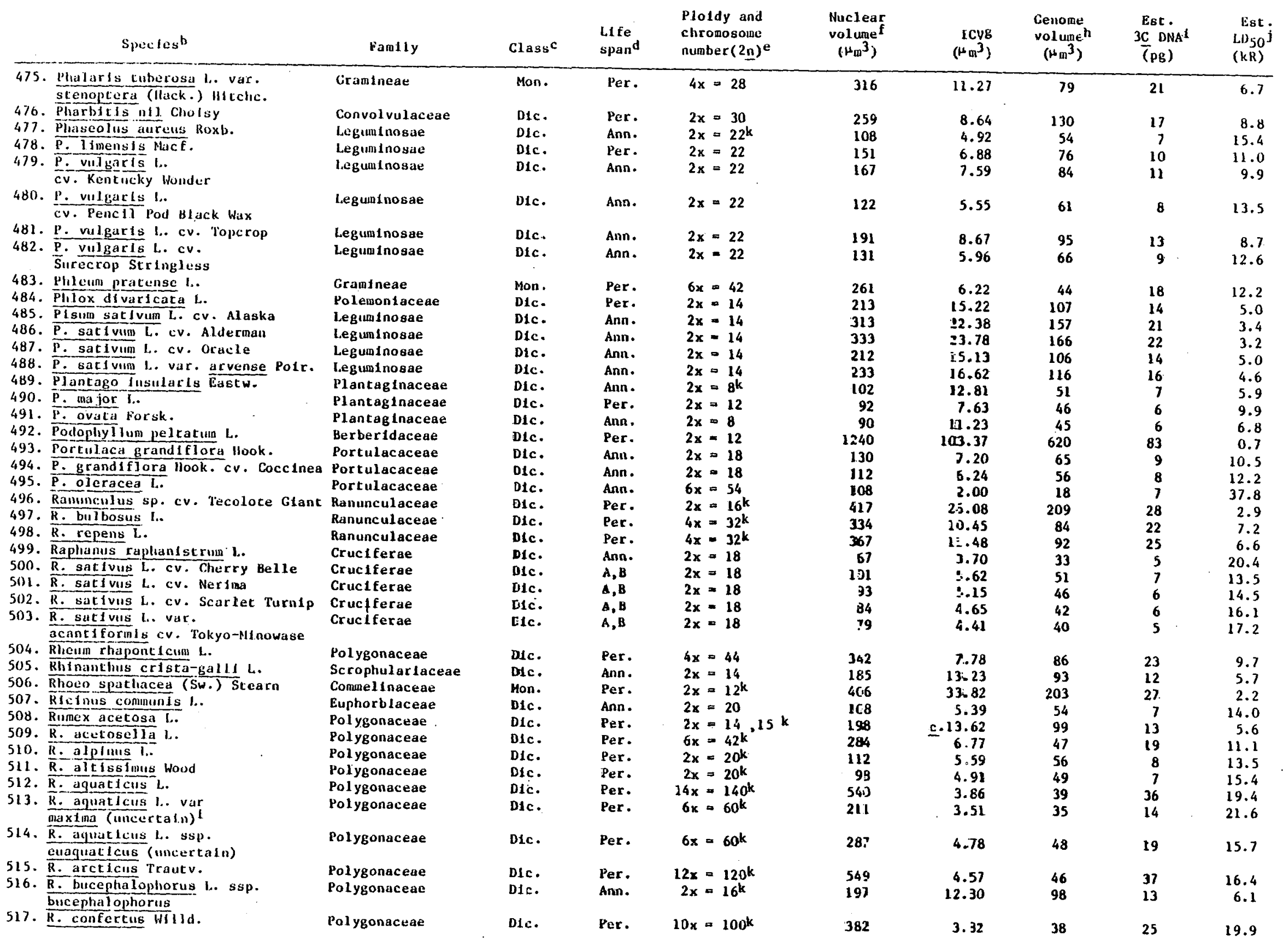


ralide 5 (cont.)

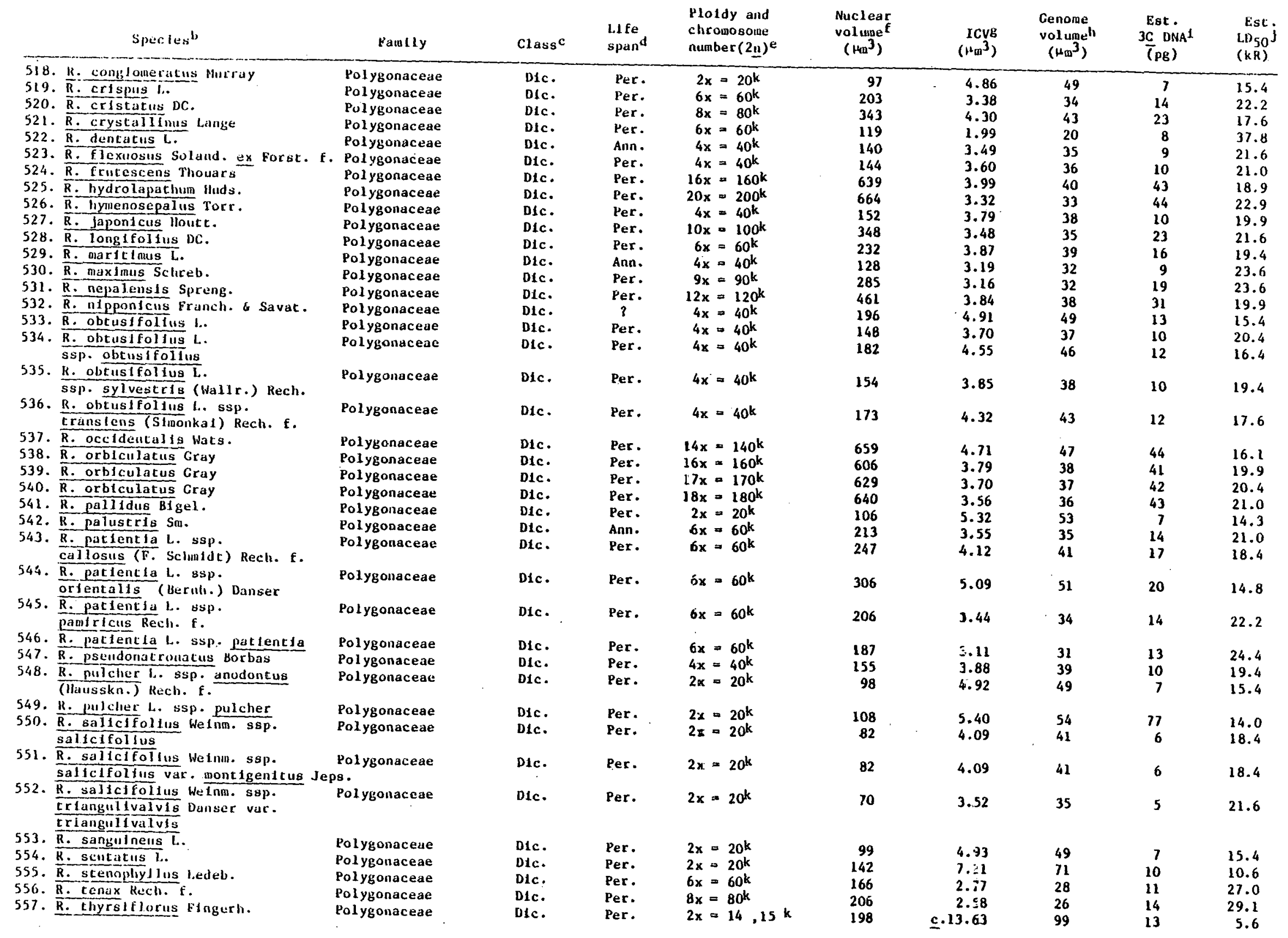


Table 5 (cont.)

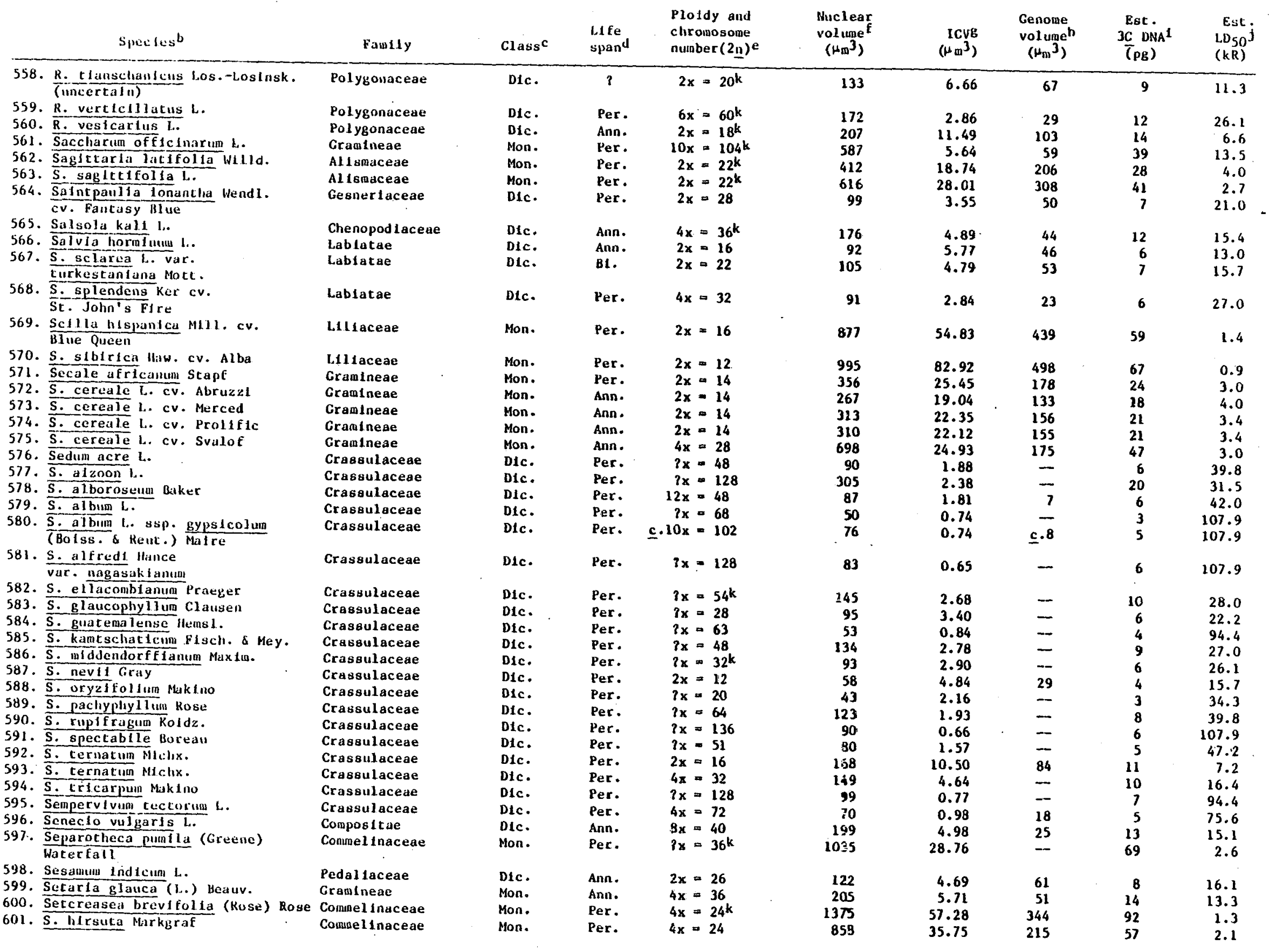


Table 5 (cont.)

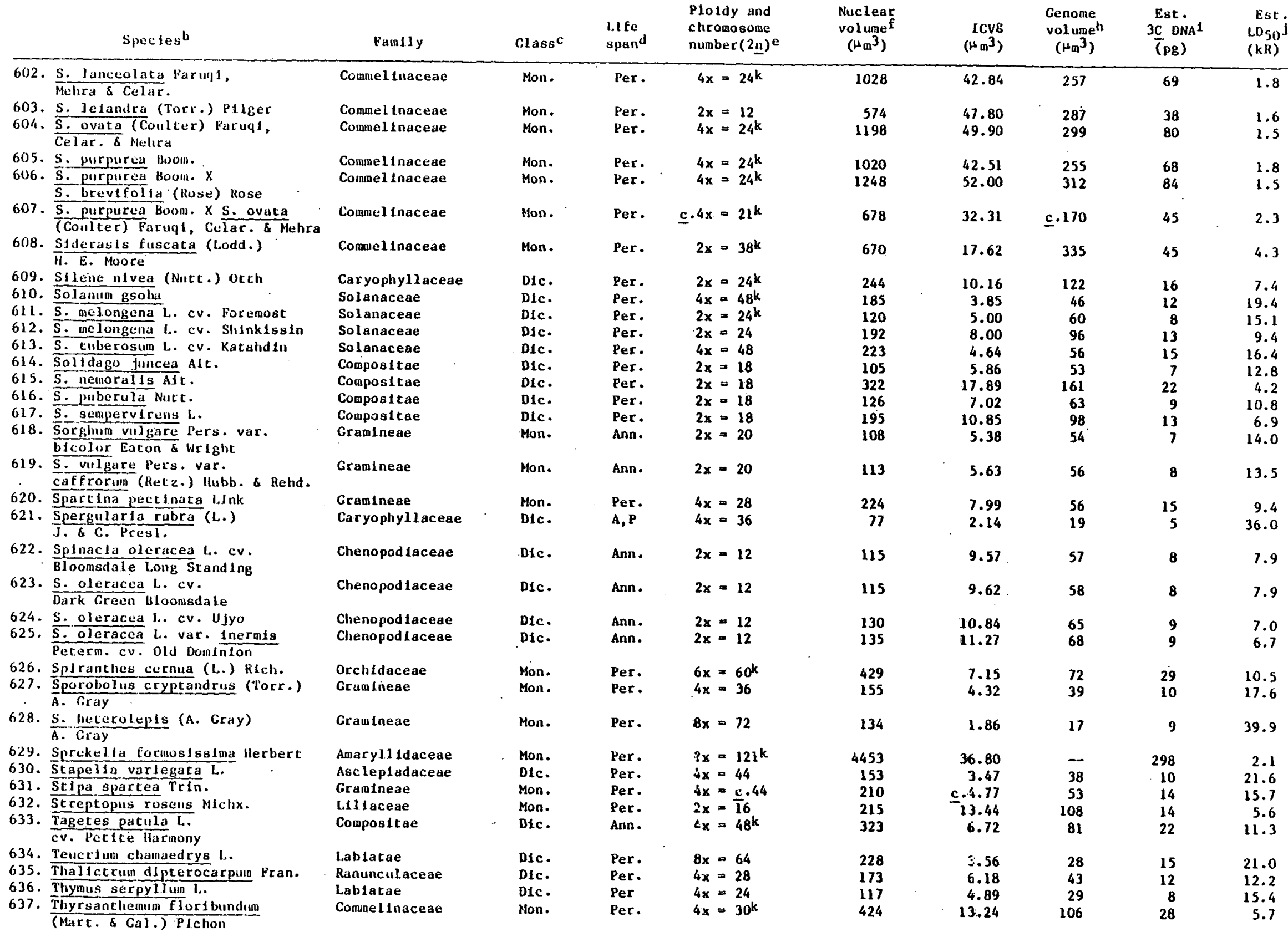


ruble 5 (cont.)

Species

Family

Ploldy and number(2n)e

vol une

Est.

Est.j

Mon. Per. 2x $=28^{k}$

638. TIgrldia pavonla Ker

638. TIgridla pavonla Ker inantia erecta (Jacq.) Schlecht. Commellnaceae

Mon.

Commel inaceae

Mon.

$4 x=68 k$

640. Tradescant 1a sp. clone 02

642. $\bar{\tau}$. Uracteata Small

Commel Inaceae

643. T. bracteata Sinall 4 T. bracteata Sinall cu. Red Cloud Comnell Inaceae

645. $\frac{T \text {. Commelinoides schult. } f \text {. }}{x-\theta(?)}$ Commellnaceae

Comme linaceae

$\frac{T}{x=}=\frac{x}{6(?)}$ comelinaldes schult. $f$.

Comellnaceae

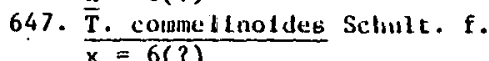

Conmellnaceae $x=6(?)$

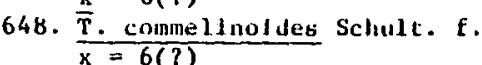

Comnel Inaceae

649. $\bar{T}$. Crassitfolla Cav.

650. T. crassifolla Cav.

652. Trerasulfolia Cav.

653. crasolfolla Cav.

654. T. crassula Link \& otto

655 T. crassula blak \& Otto

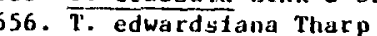

657. T. ernestlana Anders. \& Woodson

658. T. fuminensis Vell.

659. T. fluminensis Vell.

660. T. Fluminensis Vell.

661. T. fluminensis Vell.

662. T. Eluminensis Vell.

663. T. glgantea Rosit

664. T. guatemalensis C. B. Clarke

665. T. gulengolens Is Matuda

666. T. hissut 1canlis Small

667. T. litrutiflora Bush

668. T. litrsuctflora Busl

669. T. hitrsulffiora Bush $x$

T. Subacaulls Busl, clone 4430

671. T. longipes Auders. \& Woodson

672. T. micrantha Tor $r$.

673. T. navicularls ortgles

674. T. occidentalls (Britt.) Sayth

675. T. Occldentalis (Britt.) Smyth

676. T. olitensis Raf.

677. T. Ohtensis Raf.

678. T. ohiensis Raf

679. T. ozarkana Anders. \&oudson

680. T. paliulosa Anders. \& Woodson

681. T. paludosa Anders. \& Woodson

682. T paludosa Anders \& Woodsan

683. $T$. Paludosa Anders. \& Woodsan clone $12-2$
Commel lnaceae

Commel inaceae

Comnelinaceae

Conmel Inaceae

Conmelinaceae

Commel Inaceae

Comnellnaceae

Compel inaceae

Commellnaceae

Connellnaceae

Compelinaceae

Commel inaceae

Commel inaceae

Commell inaceae

Comellnacea

Commel Inacea

Comuel Inacea

Coumel inacea

Comnel inaceae

Commel inaceae

Comunelinaceae

Compel inacea

Coumel Inaceae

Commel Inacea

Comuel inaceae

Commel lnaceae

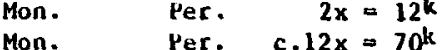

Per. c.12x $=70^{k}$

$2 x=12^{k}$

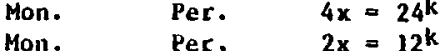

Mon. Per. 2x $=16^{k}$

Mon. Per. c. $4 x=22$

Mon.

Per. c. $5 x=29 k$

Mon.

Per.

$6 x=36^{k}$

Mon.

Mon.

Mon.

Mon.

Mon.

Mon.

Mon.

Mon.

Mon.

Mon.

Mon.

Mon.

Mon.

Mon.

Mon.

Mon.

Mon.

Mon.
Mon.

Mon.

Mon.

Mon.

Mon.

Mon.

Per.

Per.

Per.

$2 x=12^{k}$
$3 x=18^{k}$

$4 x=24 k$

$5 x=30^{k}$

$6 x=36^{k}$

c. $12 x=c .74$

$2 x=\frac{1}{12} k$

$2 x=12^{k}$

c. $10 x=\frac{c}{6} \cdot 58^{k}$

$10 x=60 k$

$11 x=60^{k}$
c. $12 x=70^{k}$

$12 x=72^{k}$
$2 x=12 k$

$2 x=12^{k}$

$4 \times 2=52^{k}$

$2 x=12^{k}$

$2 x=12^{k}$

$2 x=12^{k}$

$4 x=24 k$
$2 x=12^{k}$

$2 \mathrm{x}=12^{\mathrm{k}}$

$4 x=24 k$

$4 x=24^{k}$

$4 x=32^{k}$

$2 x=12^{k}$

$4 x=24 k$

$4 x=24 k$
$2 x=12^{k}$

$2 x=12^{k}$
$3 x=18^{k}$

$3 x=18 k$
$4 x=24^{k}$

$4 x=24 k$

$2 x=12^{k}$

$3 x=18^{k}$

$\begin{aligned} \text { Per. } & 4 x=24^{k} \\ \text { Per. } & 2 x=12^{k}\end{aligned}$

500

500
518
809

809
547

$\begin{array}{r}547 \\ 904 \\ \hline\end{array}$

904
1216

684

621

572

918

539

480

677

791
901

901
1068

484

582
639

639
657

374

470
360

417

474
893
1253

1253

520

678
652
1538

1538

801

979

1703

661

680

680

646

646

215

1215

1168

711
1005

$1 \% 64$

1764
787

Icve
$\left(+m^{3}\right)$

17.86

7.62
67.39

67.39
7.82

75.34

50.66

38.80

25.99

31.64

14.97

40.01

37.58

32.97

30.03
29.67

6.72

c.7.86

53.26

54.79

c. 6.45
7.83

5.46

5.96

6.58

72.42

24.09

43.32

54.35
64.09

66.76

81.61

70.97

27.53

20.66

56.69

50.02

50.02

53.86

55.67

50.63
48.66

48.66

59.25

55.84

60.98
65.59

250
129

129

404
c. 46

452
304

342

310

( DNA

(KR)

(kR)

$33 \quad 4.2$

4.2
9.9

1.1

9.7
1.0

1.5

2.0

2.9

c. 184

2.4

$\begin{array}{lll}90 & 36 & 5.2\end{array}$

240

226

198
180

178

40
68

c. 48
320

329
-.37
47

33
c. 35 
Table 5 (cont.)

\begin{tabular}{|c|c|c|c|c|c|c|c|c|c|}
\hline spectes bes & Fandly & $\mathrm{Class} \mathrm{C}$ & $\begin{array}{l}\text { L1fe } \\
\text { spand }\end{array}$ & $\begin{array}{l}\text { Ploldy and } \\
\text { chromosoine } \\
\text { number(2n)e }\end{array}$ & $\begin{array}{l}\text { Nuclear } \\
\text { volume } \\
\left(\mu^{3}\right)\end{array}$ & $\begin{array}{r}\text { ICVB } \\
\left(\mathrm{Hm}^{3}\right)\end{array}$ & $\begin{array}{l}\text { Genome } \\
\text { vol ume h } \\
\left(\mathrm{Hm}^{3}\right)\end{array}$ & $\begin{array}{l}\text { Est. } \\
3 \mathrm{C} \text { DNA } \\
(\mathrm{pg})\end{array}$ & $\begin{array}{l}\text { Est } \\
{\left[\begin{array}{l}1 . D_{s 0} \\
(k R)\end{array}\right.}\end{array}$ \\
\hline 684. T. plinetarmin Greene & Comnel Inaceae & Non. & Per. & $6 x=36^{k}$ & 1322 & 36.72 & 220 & 88 & 2.1 \\
\hline 685. T. reverchont Bush & Conmel Inaceae & Mon. & Per. & $4 x=24 k$ & 1375 & 57.29 & 344 & 92 & 1.3 \\
\hline 686. T. cosea Vente. & Commel Inaceae & Mon. & Per. & $4 x=24 k$ & 875 & 36.45 & 219 & 59 & 2.1 \\
\hline 687. T. Slllamonlanda Mituda & Commellinaceac & Mon. & Per. & $4 x=24 k$ & 858 & 35.74 & 214 & 57 & 2.1 \\
\hline 6B8. T. subacaul is Bush & Commel inaceae & Mon. & Per. & $2 x=12^{k}$ & 227 & 60.56 & 363 & 49 & 1.2 \\
\hline 689. T. subaspera Ker-liawl. & Comine IInaceae & Mon. & Per. & $4 x=24 k$ & 1107 & 46.14 & 277 & 74 & 1.6 \\
\hline 690. T. sibtilis Matuda & Commel Inaceae & Mon. & Per. & $2 x=12^{k}$ & 795 & 66.22 & 397 & 53 & 1.1 \\
\hline 691. T. Eepoxt1ana Matuda & Comnel Inaceae & Mon. & Per. & $2 x=12^{k}$ & 534 & 44.53 & 267 & 36 & 1.7 \\
\hline 692. $\overline{\mathrm{T}}$. tol fuanens $1 \mathrm{~s}$ hat uda & Comunel lnaceae & Mon. & Per. & $4 x=24 k$ & 668 & 27.83 & 167 & 45 & 2.7 \\
\hline 693. T. Lonalamonticola Matuda & Conunelfinace ae & Mon. & Per. & $2 x=12$ & 231 & 19.21 & 115 & 15 & 3.9 \\
\hline 694. T. vIrglntana $\mathrm{L} .$. & Commel Inaceae & Mon. & Per. & $4 x=24 k$ & 1116 & 46.53 & 279 & 74 & 1.6 \\
\hline 695. T. vlrginiana L. liybrid & Comnell lnaceae & Mon. & Per. & $\underline{c} \cdot 3 x=19 k$ & 1159 & 60.99 & c. 579 & 78 & 1.2 \\
\hline 696. T. virglinlana L. hybrid & Commellnaceae & Mon. & Per. & $\bar{E} .4 x=21^{k}$ & 950 & 45.25 & c. 475 & 64 & 1.7 \\
\hline 697. T. virntulana L. hybrid & Comne llnaceae & Mon. & Per. & $E .4 x=23^{k}$ & 1280 & 55.65 & c. 320 & 86 & 1.4 \\
\hline 698. $\frac{T \text { virginlana }}{\text { IrIs Pricliard }}$.. cv. & Commel Inaceae & Mon. & Per. & $-4 x=24^{k}$ & 1332 & 55.50 & 333 & 89 & 1.4 \\
\hline 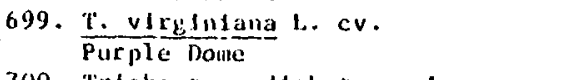 & Conumel Inaceae & Mon. & Per. & $4 x=24 k$ & 1381 & 57.54 & 345 & 92 & 1.3 \\
\hline 700. Trichostema dichotomum L. & Lablatae & Dic. & Ann. & $2 x=38$ & 140 & 3.67 & 70 & 9 & 20.4 \\
\hline 701. Tridax procumbens L. & Compositae & DIc. & Arn. & $2 x=36$ & 491 & 13.65 & 246 & 33 & 5.5 \\
\hline $\begin{array}{l}\text { 702. Trldens pulchellus (IHSK) Jitchic. } \\
\text { 703. Trifolfum hirtumAll. }\end{array}$ & $\begin{array}{l}\text { GrainIneac } \\
\text { LegumInosae }\end{array}$ & $\begin{array}{l}\text { Mon. } \\
\text { Dic. }\end{array}$ & $\begin{array}{l}\text { Per. } \\
\text { Ann. }\end{array}$ & $\begin{array}{l}2 x=16^{k} \\
2 x=10^{k}\end{array}$ & $\begin{array}{l}53 \\
98\end{array}$ & $\begin{array}{l}3.33 \\
9.82\end{array}$ & $\begin{array}{l}27 \\
49\end{array}$ & 4 & 22.9 \\
\hline 704. T.pratense $\mathrm{l}$. & $\begin{array}{l}\text { Leguminosae } \\
\text { Leguminosae }\end{array}$ & Dic. & Per. & $2 x=14$ & 74 & 5.28 & 37 & 5 & 14.3 \\
\hline 705. T. repens T.. (S184) & Leguminosae & Dic. & Per. & $4 x=32^{k}$ & 94 & 2.93 & 23 & 6 & 26.1 \\
\hline 706. T. repens L. c.v. White Dutch & Leguminosae & Dic. & Per. & $4 x=32^{k}$ & 110 & 3.44 & 28 & 7 & 22.2 \\
\hline 707. T. repens 1. cv. Yugoslavian & Leguminosae & Dic. & Per. & $4 x=32^{k}$ & 99 & 3.11 & 25 & 7 & 24.4 \\
\hline 708. Trilifua aputalon Maklno & Lllaceae & Mon. & Per. & $4 x=20^{k}$ & 2242 & 112.08 & 560 & 150 & 0.7 \\
\hline 709. T. cernum $\mathrm{L}$ & LHIaceae & Mon. & Per. & $2 x=10^{k}$ & 1063 & 106.33 & 532 & 71 & 0.7 \\
\hline 110. T. erectum 1. & Lfllaceae & Mon. & Per. & $2 x=10^{k}$ & 1206 & 120.60 & 603 & 81 & 0.6 \\
\hline 711. T. erectum L. var. album Purgh. & Ltl1aceae & Mon. & Per. & $2 x=10$ & 999 & 99.85 & 499 & 67 & 0.8 \\
\hline 712. T. grandiflorum (Michx.) Salisb. & Lillaceae & Mon. & Per. & $2 x=10$ & 1553 & 155.31 & 717 & 104 & 0.5 \\
\hline 713. T. hagae Mlyabe \& Tatewaki & Lll aceae & Mon. & Per. & $6 x=30$ & 2843 & 94.78 & 474 & 190 & 0.8 \\
\hline 714. T. kantsclial lcum Yall. & L111aceae & Mon. & Per. & $2 x=10$ & 890 & 89.04 & 445 & 60 & 0.9 \\
\hline 715. T. Luteum (Muh1.) llarb. & Llllaceae & Mon. & Per. & $2 x=10$ & 1936 & 193.64 & 968 & 130 & 0.4 \\
\hline 716. T. sessite 1 & Lll laceae & Mon. & Per. & $2 x=10$ & 1180 & 118.04 & 590 & 79 & 0.6 \\
\hline 717. T. sty]losum Nutt. & L11 taceae & Mon. & Per. & $2 x=10$ & 785 & 78.53 & 393 & 53 & 1.0 \\
\hline 718. T. undulatum Willd. & LHIaceae & Mon. & Per. & $2 x=10$ & 1489 & 148.92 & 745 & $\cdot 100$ & 0.5 \\
\hline 719. Tripogandra dluret 1ca & Comme1lnaceae & Mon. & Per. & $8 k=64 k$ & 501 & 7.83 & 63 & 34 & 9.7 \\
\hline 720. $\frac{\text { T.elomgata (C. F. W. Mey.) }}{\text { Woodson }}$ & Conmel Inaceae & Mon. & Per. & $B I=64 k$ & 657 & 10.27 & 82 & 44 & 7.3 \\
\hline 721. T. Blandulasa (Seuberc) Rohu. & Comrel Inaceae & Mon. & Per. & $2 x=16^{k}$ & 306 & 19.12 & 153 & 21 & 4.0 \\
\hline 722. $\frac{\mathrm{T} \cdot \text { grandiflora }}{\text { Woodson (Donn. Sa.) }}$ & Commel inaceae & Mon. & Per. & $2 x=16^{k}$ & 343 & 21.46 & 172 & 23 & 3.5 \\
\hline 723. T. surntana llandlos (Ined.) & Conmel I naceae & Mon. & Per. & c. $5 x=42^{k}$ & 636 & 15.15 & c. 127 & 43 & 5.0 \\
\hline 724. T. multiflora (Sw.) Raf. & Commell naceae & Man. & Per. & $-8 x=64 k$ & 462 & 7.22 & -58 & 31 & 10.5 \\
\hline 725. T. serrulata (Vahl) Handlos & Comalel Inaceae & Mon. & Per. & $4 x=32^{k}$ & 410 & 12.80 & 102 & 27 & 5.9 \\
\hline 726. T. Serrulata (Valul) Handlos & Commel laceae & Man. & Per. & $6 x=48^{k}$ & 530 & 11.04 & 88 & 35 & 6.9 \\
\hline 727. Tritlcale & Gramincae & Mon. & Ann. & $6 x=42$ & 750 & 17.86 & 125 & 50 & 4.2 \\
\hline 728. Trltcale & Gramineate & Mon. & Ann. & $8 x=56$ & 806 & 14.39 & 101 & 54 & 5.2 \\
\hline 729. Trirlcun ateglopoldes Thurb. & Cramilueae & Mlon. & Ann. & $2 x=14$ & 243 & 17.35 & 121 & 16 & 4.3 \\
\hline
\end{tabular}


lable 5 (cont.)

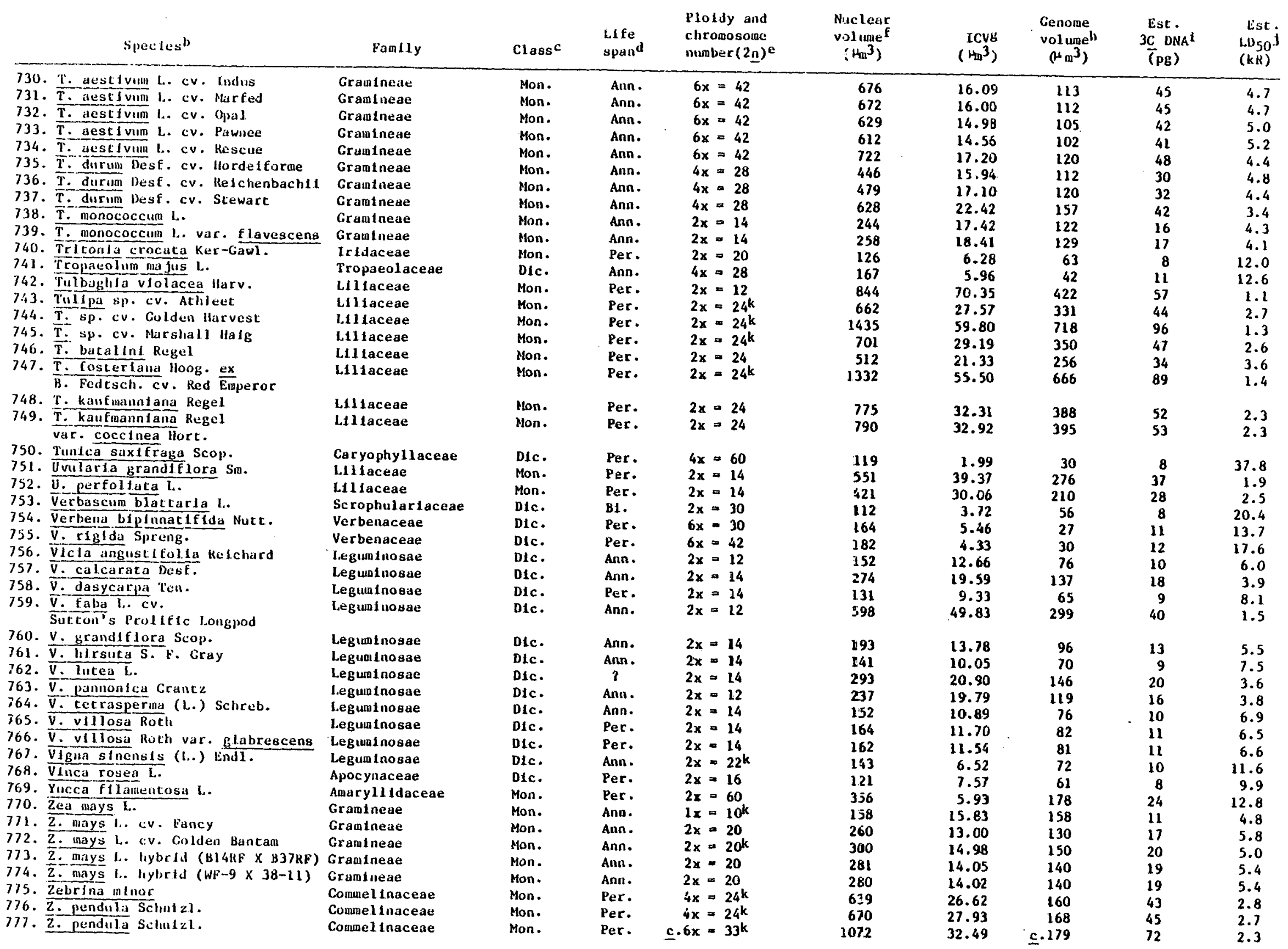


Table 5 (cont.)

\begin{tabular}{|c|c|c|c|c|c|c|c|c|c|}
\hline speciesb & Fatn1ly & Class $\mathrm{c}$ & $\begin{array}{l}\text { Life } \\
\text { spand }\end{array}$ & $\begin{array}{l}\text { Ploidy and } \\
\text { chromosome } \\
\text { number }(2 n)^{e}\end{array}$ & $\begin{array}{l}\text { Nuclear } \\
\text { volume } \\
\left.\left(\mu_{m}\right)^{3}\right)\end{array}$ & $\begin{array}{r}\text { ICVB } \\
\left(\mu_{m}^{3}\right)\end{array}$ & $\begin{array}{l}\text { Cenome } \\
\text { volume } \\
\left(\mu_{m}{ }^{3}\right)\end{array}$ & $\begin{array}{l}\text { EsE. } \\
\frac{3 C \text { DNA }}{(P g)}\end{array}$ & $\begin{array}{l}\text { Est } \\
\mathrm{LD}_{50} \mathrm{j} \\
(\mathrm{kK})\end{array}$ \\
\hline 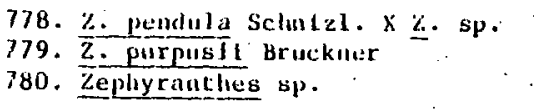 & $\begin{array}{l}\text { Commel Inaceae } \\
\text { Commel Inaceae } \\
\text { Amaryllidaceae }\end{array}$ & $\begin{array}{l}\text { Mon. } \\
\text { Mon. } \\
\text { Mon. }\end{array}$ & $\begin{array}{l}\text { Per. } \\
\text { Per. } \\
\text { Per. }\end{array}$ & $\begin{array}{r}c .4 x=22^{k} \\
4 x=24^{k} \\
2 x=12^{k}\end{array}$ & $\begin{array}{l}866 \\
604 \\
875\end{array}$ & $\begin{array}{l}39.38 \\
25.17 \\
72.89\end{array}$ & $\begin{array}{r}c: 217 \\
151 \\
437\end{array}$ & $\begin{array}{l}58 \\
40 \\
59\end{array}$ & $\begin{array}{l}1.9 \\
3.0 \\
1.0\end{array}$ \\
\hline
\end{tabular}

a few spectes listed here ace actually fibrous (e.g. Agave) or subshrubby (e.g. Drosophyllum, some Hiblscus spp.;, rather than truly herbaceous.

'Subspectes, vars., cultivars, and different ploidy ievels are all considered separately. Unidentified species within a genus are generally onitied, except when part of a polyploid serles or when an unknown ts the only representative of lics genus.

cimocot or dicut.

dAnnal, blennlat or perennial. Some plants wilch are cultivated as annuals are actually perennials (e.g. Lycoperaicon esculentum).

esome genera have wore than one base number (e.g. All fum) and in some genera the base number has not been agcertalned.

Frhese values may difter froto prevlously-published figures. In most such cases, the values given here are averages of several deterainations. All

SICVs were calculated before nuclear volumes were rounded of to whole numbers. Thus ICVs derived from the same apparent nuclear volume may not agree precisely.

The volume of a slngle basic chromosome complement, estimated by dividing nucleax volume by ploidy level. Differences in genome volume, or in DNa per genome, have been sliown to have possible evolut lonary algnificance (Sparrow and Nauman 1973, 1976).

Est imated from nuclear volume using the correlation demonstrated by Baetcke et al. (1967). See discusston in text and Figs. 1 , 4. kestimaced fron 1 Cv as described by Sparrow \& Schwemer (1974).

Chromosome count deternined or confirmed in A. H. Sparrow laboratory. All others from the literature. 
Table 6

Famlly, class, ploldy, chromosome number, nuclear volume, Interphase chromosome volume (ICV), genome

volume, estluated 3C DNA content and est 1mated $L D_{50}$ of $362 \mathrm{spectes}$ of woody plants

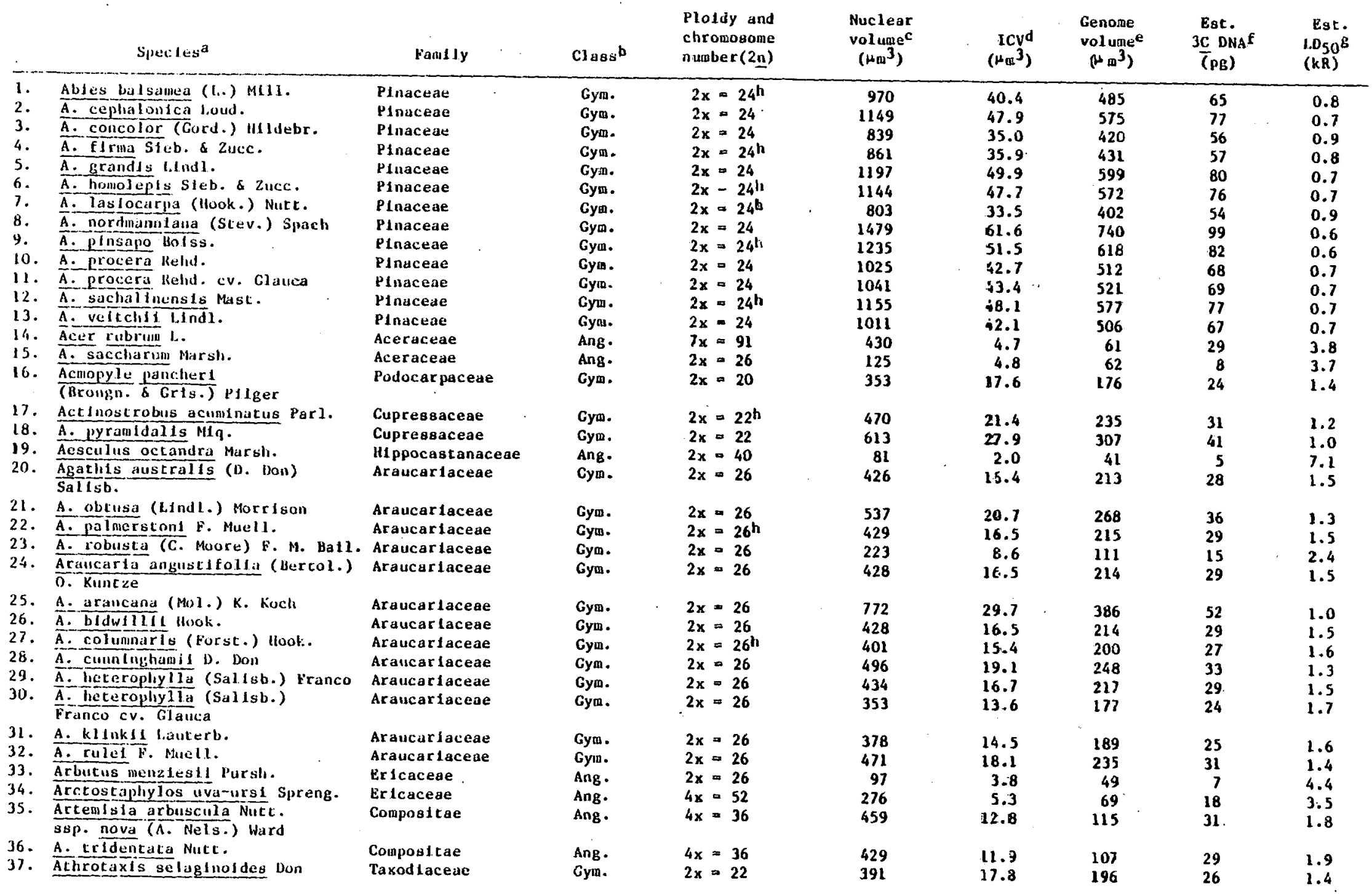


I'ul:te 6 (cont.)

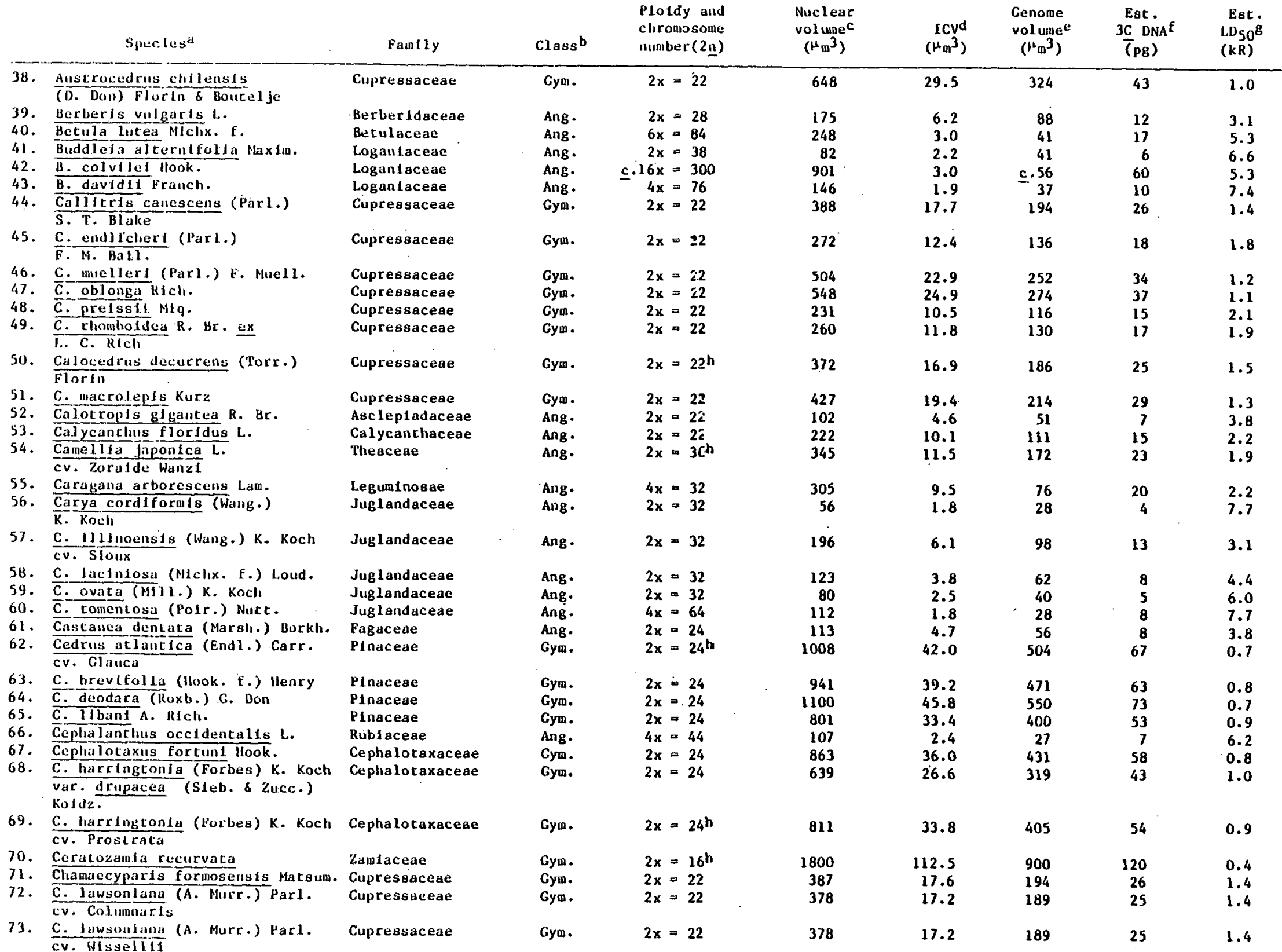


l'able 6 (cont.)

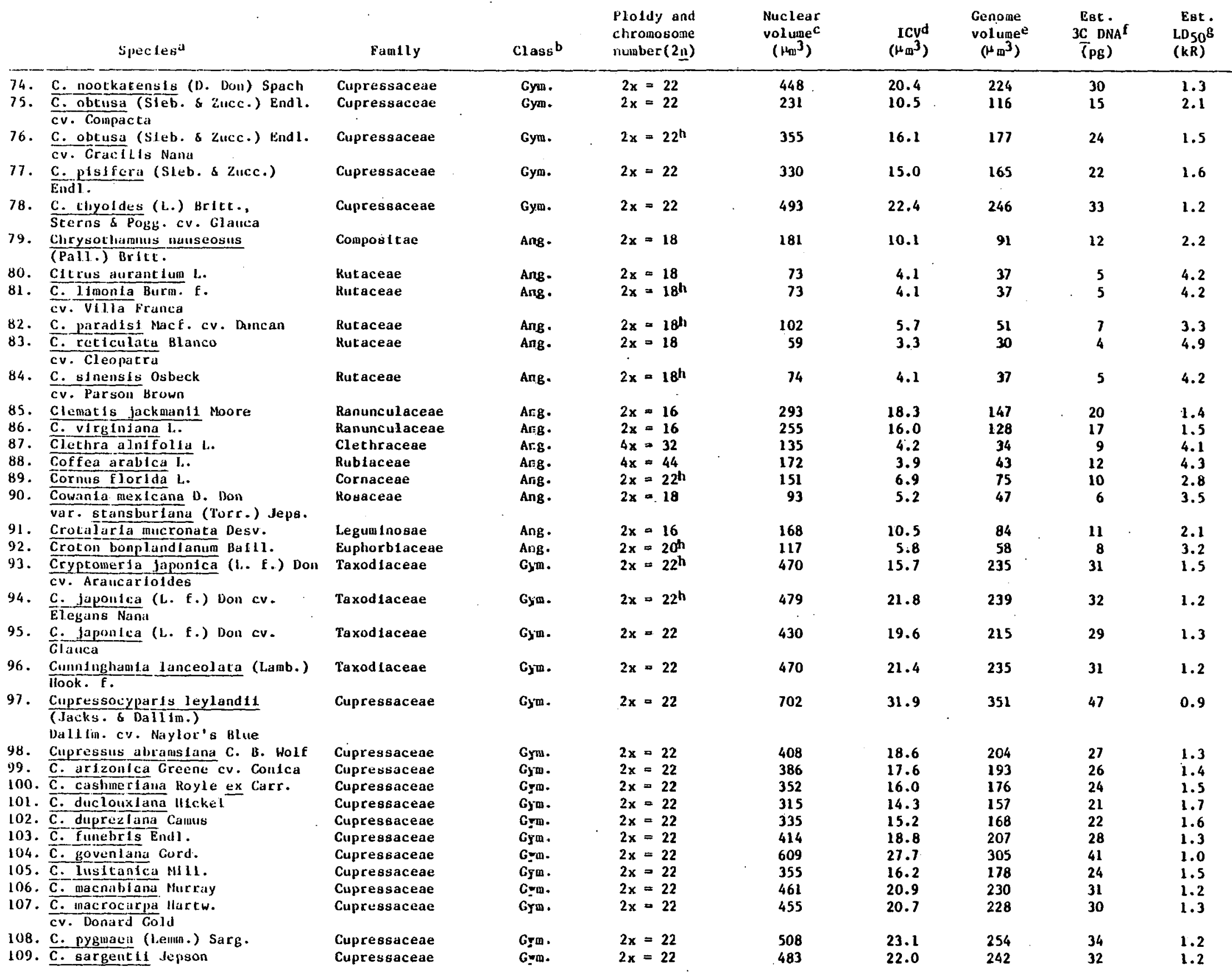


Table 6 (cont.)

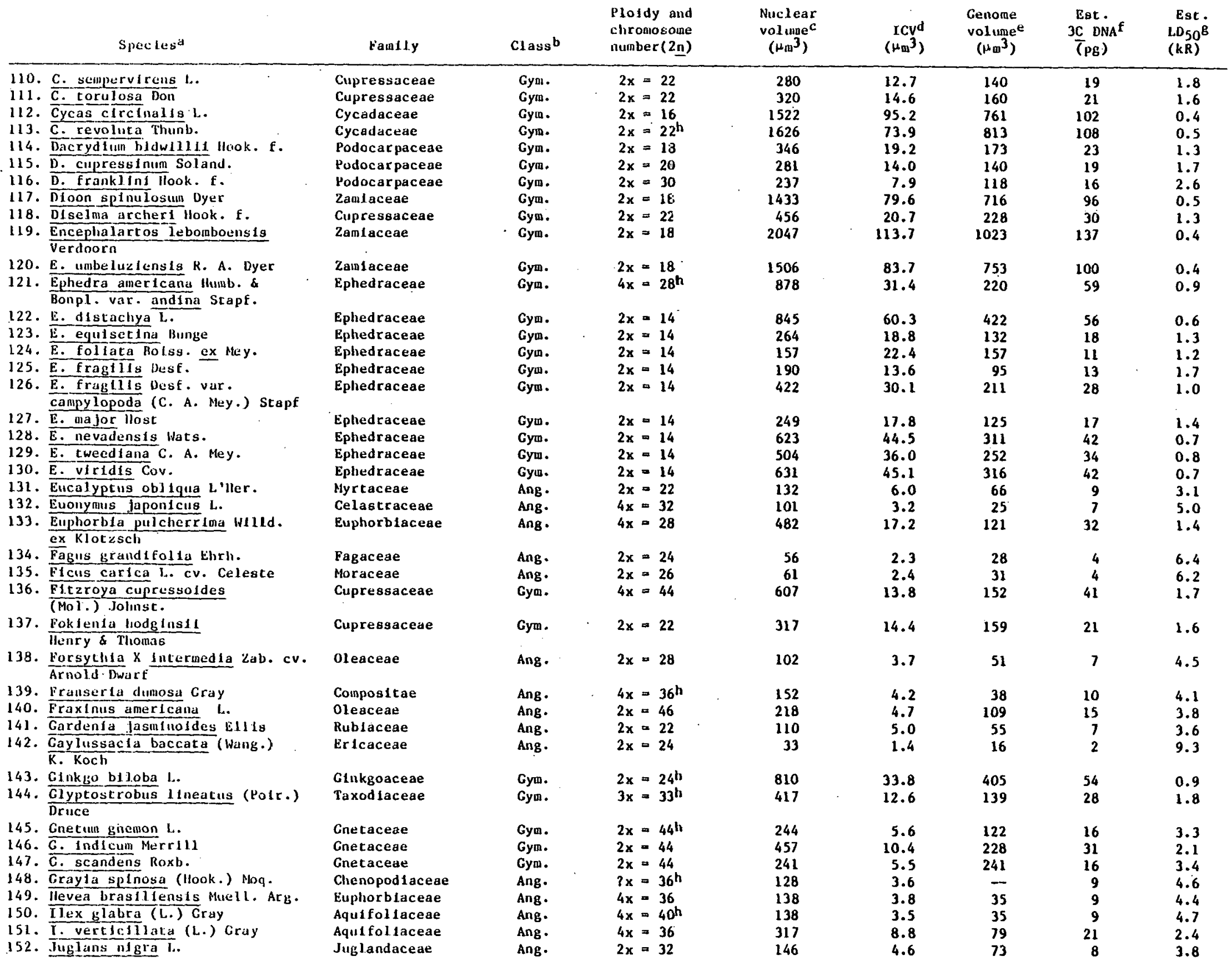


Table 6 (cont.)

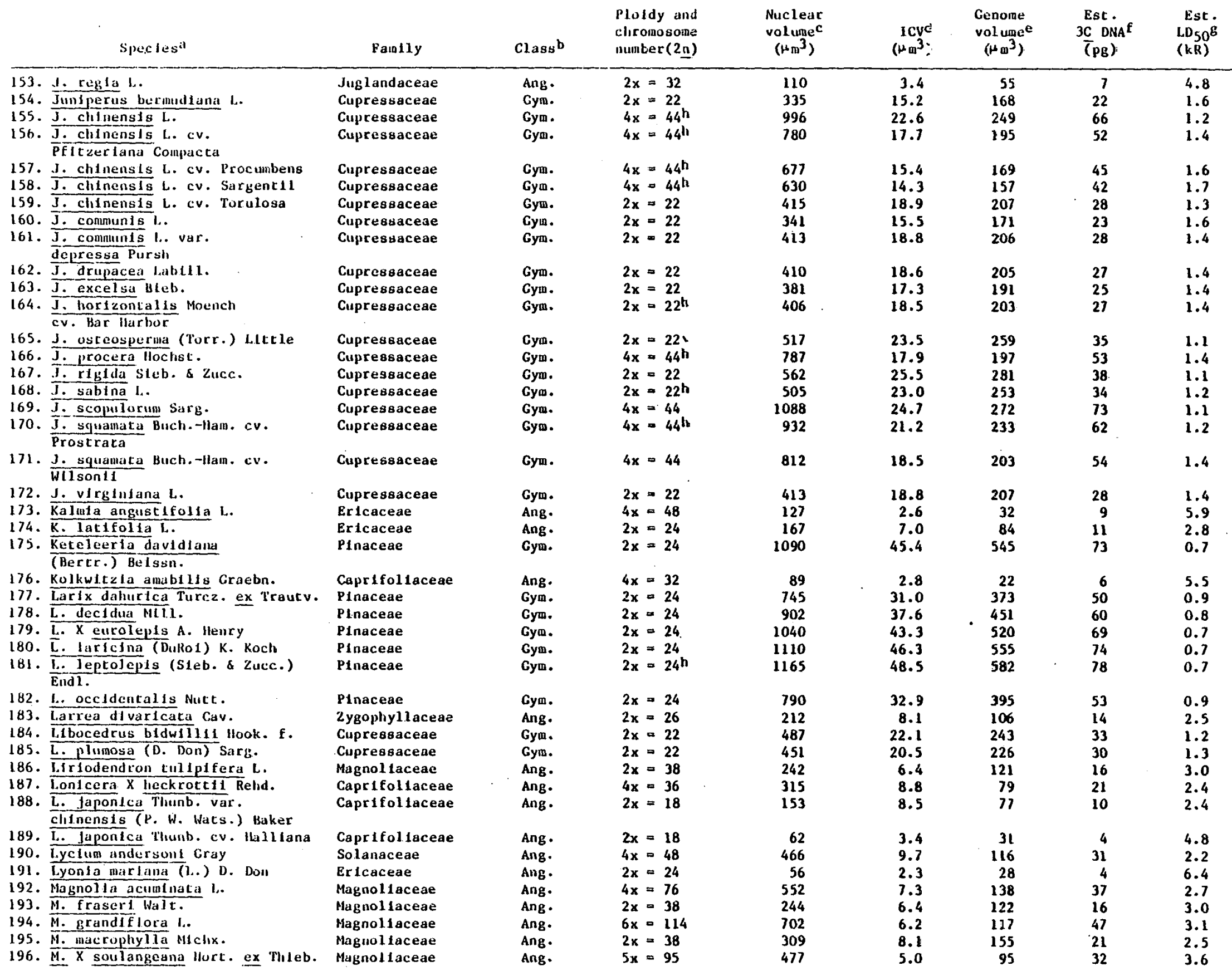


lable 6 (cont.)

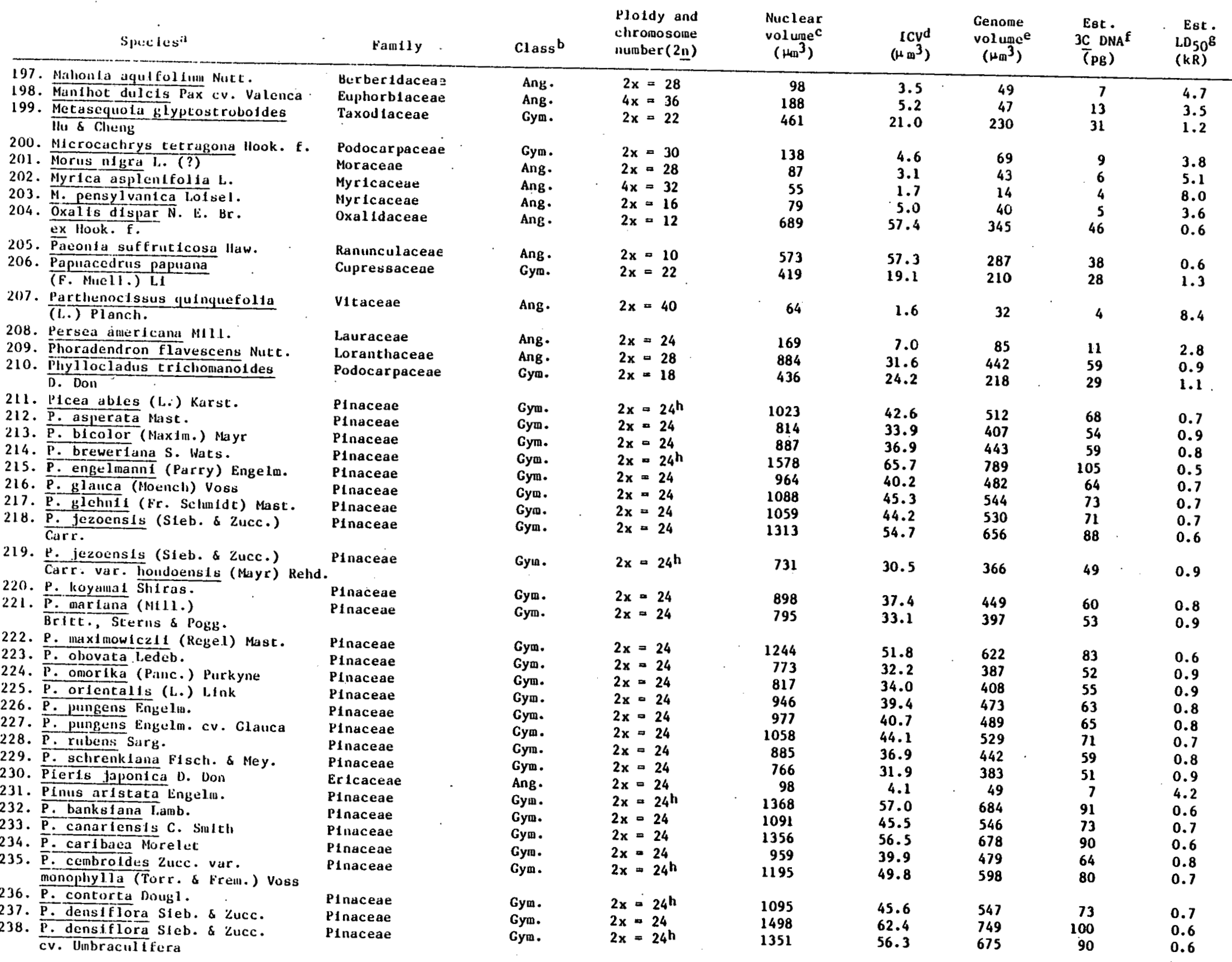




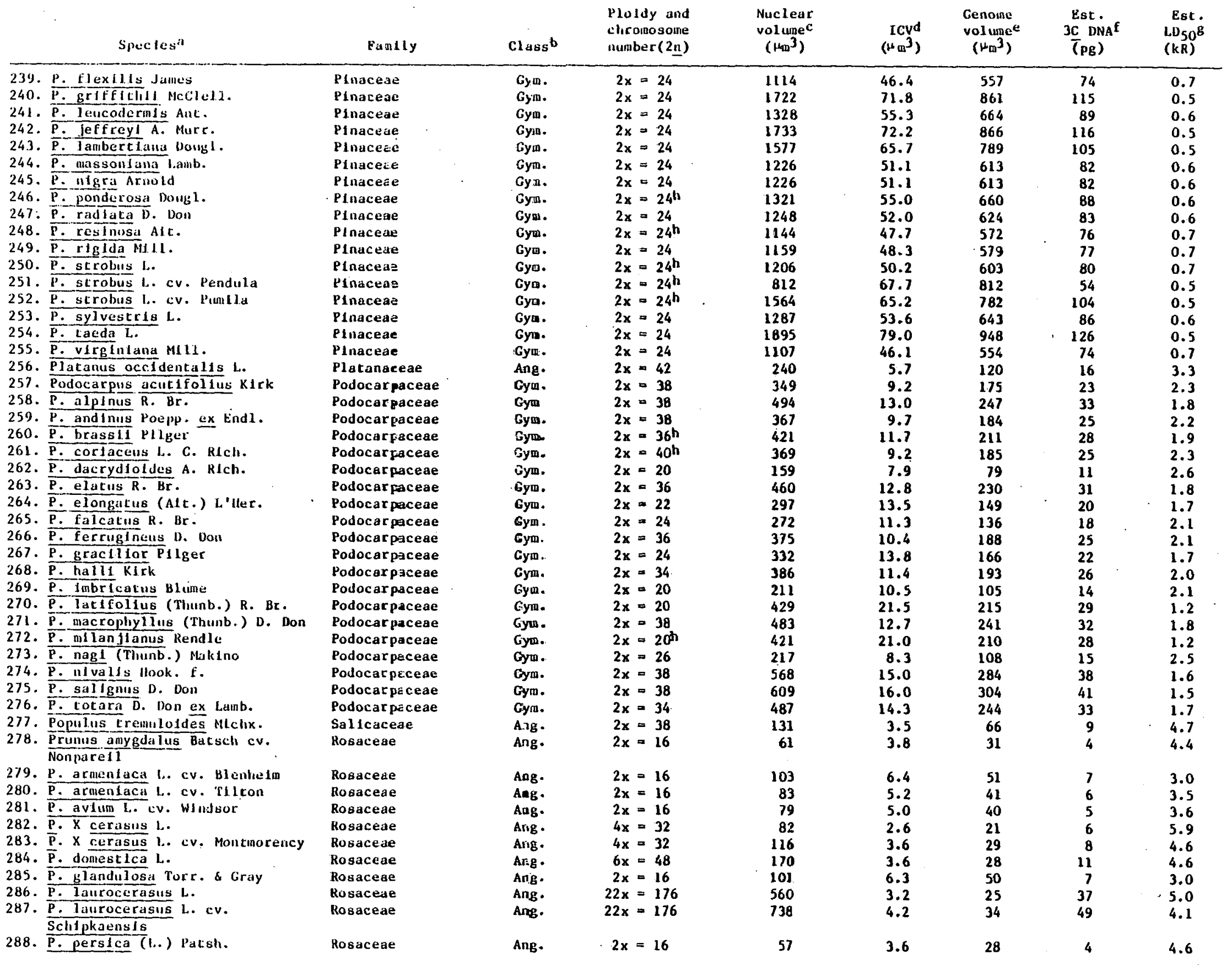




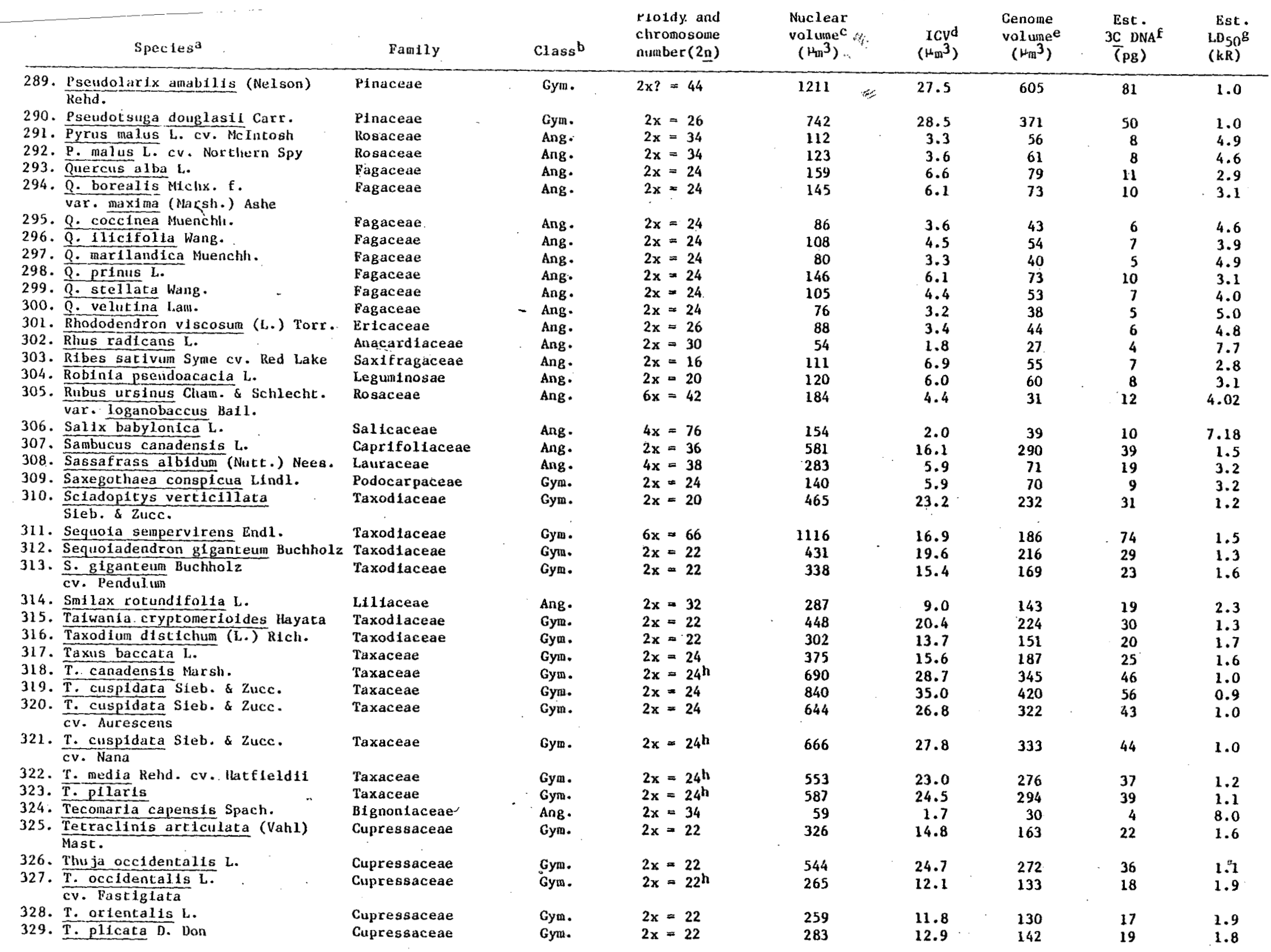


Table 6 (cont.)

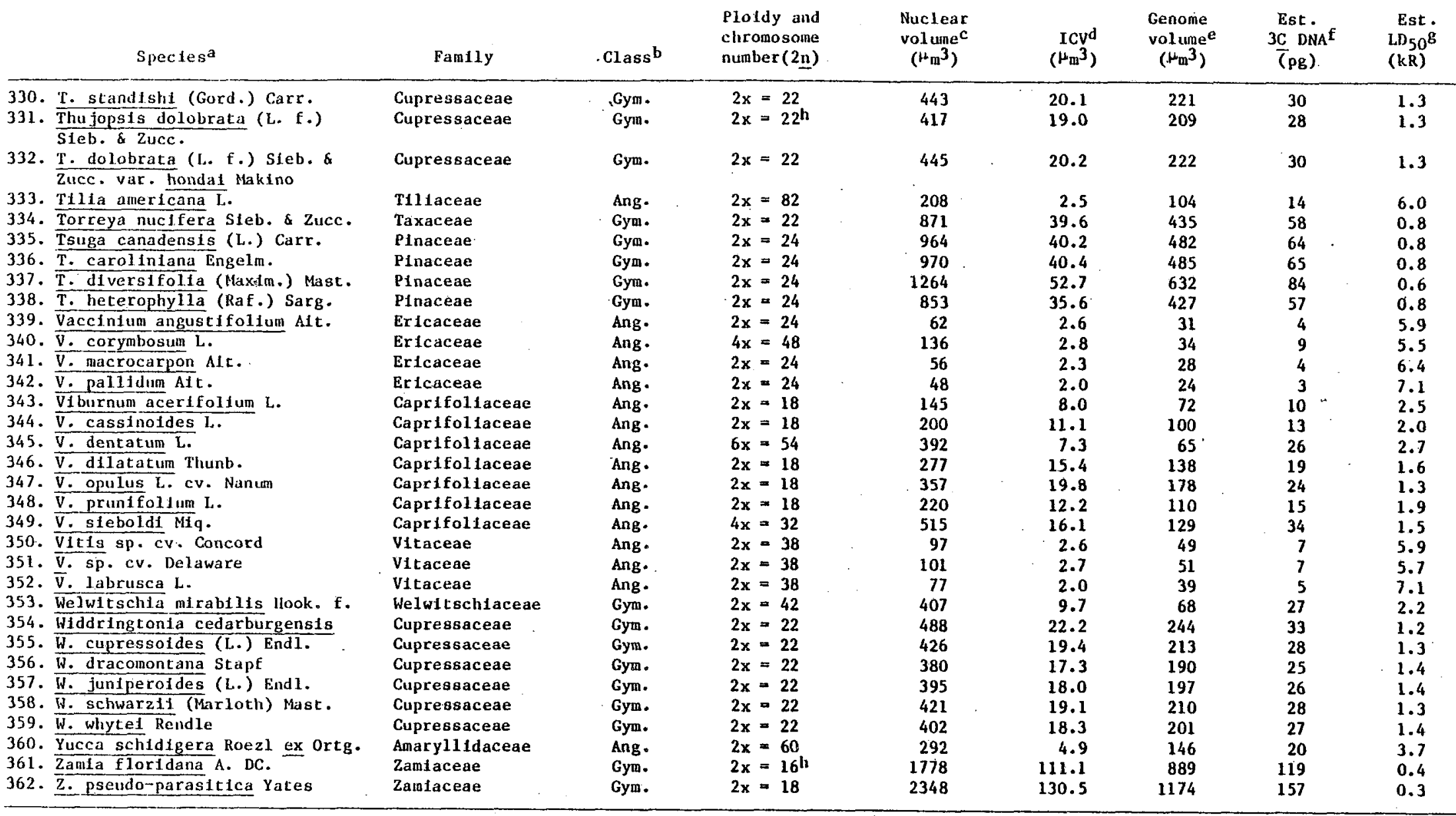

a Subspecies, vars, and cultivars are all considered separately.

Anglosperin or gyinosperm.

CNuclear volumes ufther determined from actively-growing material or, if from dormant material, converted to the active equivalent, as described in Sparrow, Rogers \& Schweruner (1964) and Sparrow, Schwemmer, Klug \& Puglielli (1970a). Values listed here may differ from previously-published figures. In most such cases, the values given here are averages of several determinations. All volumes determined in A. H. Sparrow laboratory.

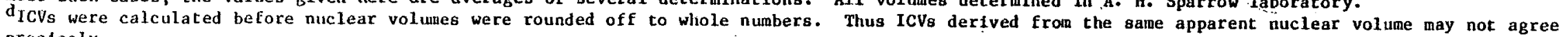
prectisely.

The volune of a single basic chromosome complement, estimated by dividing nuclear volume by ploidy level. Differences in genome volume, or in DNA per genome, have been shown to have possible evolutlonary slgnificance (Sparrow \& Nauman, 1973, 1976).

Estimated from nuclear volume using the correlation demonstrated by Baetcke, Sparrow, Nauman \& Schwemuer (1967). See also discussion in text and Figs. 1,4

EEtimated frou ICV as described in Sparrow, Rogers \& Schwemmer (1968).

hChromosome counts determined or confirmed in $\Lambda$. h. Sparrow laboratory. All others from the literature. 